NIST Special Publication 260-156

\title{
Certification of NIST Standard Reference Material 1575a Pine Needles and Results of an International Laboratory Comparison
}

Elizabeth A. Mackey, Donald A. Becker, Rabia O. Spatz, Rick L. Paul, Robert R. Greenberg, Richard M. Lindstrom, Lee L. Yu, Laura J. Wood, Stephen E. Long, W. Robert Kelly, Jacqueline L. Mann, Bruce S. MacDonald, Stephen A. Wilson, Zoe A. Brown, Paul H. Briggs, and James Budhan 
National Institute of Standards and Technology • Technology Administration • U.S. Department of Commerce 


\section{Certification of NIST Standard Reference Material 1575a Pine Needles and Results of an International Laboratory Comparison}

Elizabeth A. Mackey, Donald A. Becker, Rabia D. Oflaz, Rick L. Paul, Robert R. Greenberg, Richard M. Lindstrom, Lee L. Yu, Laura J. Wood, Stephen E. Long, W. Robert Kelly, Jacqueline L. Mann Analytical Chemistry Division Chemical Science and Technology Laboratory National Institute of Standards and Technology

Gaithersburg, MD 20899 USA

Bruce S. MacDonald Standards Reference Materials Group

Technology Services National Institute of Standards and Technology Gaithersburg, MD 20899 USA

Stephen A. Wilson, Zoe A. Brown, Paul H. Briggs, and James Budhan United States Geological Survey Denver CO, 80225 USA

June 2004

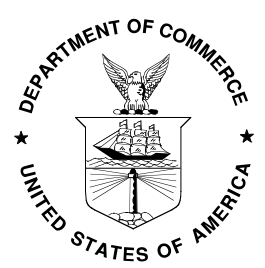

U.S. Department of Commerce Donald L. Evans, Secretary

Technology Administration Phillip J. Bond, Under Secretary for Technology

National Institute of Standards and Technology Arden L. Bement, Jr., Director 
Certain commercial entities, equipment, or materials may be identified in this document in order to describe an experimental procedure or concept adequately. Such identification is not intended to imply recommendation or endorsement by the National Institute of Standards and Technology, nor is it intended to imply that the entities, materials, or equipment are necessarily the best available for the purpose.

National Institute of Standards and Technology Special Publication 260-156 Natl. Inst. Stand. Technol. Spec. Publ. 260-156, 71 pages (June 2004) CODEN: NSPUE2

U.S. GOVERNMENT PRINTING OFFICE WASHINGTON: 2004

For sale by the Superintendent of Documents, U.S. Government Printing Office Internet: bookstore.gpo.gov — Phone: (202) 512-1800 — Fax: (202) 512-2250 Mail: Stop SSOP, Washington, DC 20402-0001 


\section{Contents}

$\begin{array}{lc}\text { Abstract } & \mathrm{V} \\ \text { Acknowledgments } & \text { vi } \\ \text { Introduction } & 1 \\ \text { Material Collection and Preparation } & 1 \\ \text { Experimental Procedures } & 3 \\ \text { Results and Discussion } & 8 \\ \text { Certification and Data Analysis } & 8 \\ \text { Interlaboratory Comparison Procedures } & \\ \text { Interlaboratory Comparison Results } & \\ \text { Summary and Conclusions } & \end{array}$

Appendix A Results of Certification Analyses of Individual Portions of SRM 1575a Performed at NIST and at USGS

Appendix B Copy of the SRM 1575a Pine Needles Certificate of Analysis

Appendix C List of Participants in the ASTM Interlaboratory Comparison

Appendix D Analytical Results from Each Participant in the ASTM Interlaboratory Comparison Coded by Participant Numbers

Appendix E Analytical Results for Each Element Reported by Participants Compared with Certificate Values and Interlaboratory Averages 


\begin{abstract}
NIST recently released SRM 1575a Pine Needles to replace the original SRM 1575 Pine Needles, which was issued in 1976 and is now out of stock. This material is intended primarily for use in the evaluation of inorganic analytical techniques used to determine element content of botanical and agricultural materials that have a matrix similar to pine needles. The needles were collected in North Carolina from freshly felled loblolly pine (Pinus taeda) trees of about the same age. The needles were dried, ground, jet-milled, blended, sterilized, and bottled. Elemental analyses of this material were performed at NIST using five analytical techniques and at the U.S. Geological Survey in Denver, CO using three techniques. Selected data were used to provide certified mass fraction values for twelve elements, reference values for eleven elements, and information values for two elements. This material was also used as a test material for an international interlaborartory comparison exercise for the determination of elemental composition sponsored by the ASTM Task Group on Nuclear Methods of Chemical Analysis. A complete description of the material collection and preparation, the results of analyses, the methods used to assign certified, reference, and information values, and results of the interlaboratory comparison exercise are presented and discussed in this report.
\end{abstract}

Key Words: certified value, interlaboratory comparison, pine needles, reference material, round robin, Standard Reference Material (SRM), trace elements 


\section{ACKNOWLEDGEMENTS}

The authors wish to acknowledge the North Carolina State University's Forest Nutrition Cooperative who under the direction of Research Assistant Professor Daniel L. Kelting collected, dried, and coarse-ground the pine needles for SRM 1575a. We gratefully acknowledge the hard work done by Curtis Fales of the SRM Group who jetmilled, blended, and bottled this material in record time, under difficult conditions. The authors gratefully acknowledge the assistance of the staff of the NIST Center for Neutron Research, Operations Group during the activation analysis experiments. The NIST staff greatly appreciates the opportunity to collaborate with the U.S. Geological Survey analysts without whom certification of this material would not have been possible. 


\section{INTRODUCTION}

In September of 2002, the National Institute of Standards and Technology (NIST) released Standard Reference Material (SRM) 1575a Pine Needles. This material was provided to replace NIST SRM 1575 Pine Needles, which is now out of stock. This renewal material is one of five NIST agricultural certified reference materials that are intended for use in the evaluation of analytical methods for the determination of element content of botanical materials. Analysis of SRM 1575a Pine Needles presents a different analytical challenge as compared with the other agricultural reference materials due to differences in both matrix and levels of some elements. For example, mass fractions of $\mathrm{B}, \mathrm{Ca}, \mathrm{K}$, and Fe are significantly lower than in the other botanical SRMs whereas the mass fraction of Mn is significantly higher.

The material was collected, dried, and ground by the Forest Nutrition Cooperative of North Carolina State University and shipped to NIST for further processing and bottling.

Determination of the elemental composition of the material was accomplished through a collaboration of NIST with the U.S. Geological Survey (USGS) Denver, CO. Scientists at NIST used inductively coupled plasma mass spectrometry (ICP-MS), cold vapor isotope dilution mass spectrometry (CV-IDMS), instrumental neutron activation analysis (INAA), prompt gamma-ray activation analysis (PGAA), and three different radiochemical neutron activation analysis (RNAA) procedures for the determination of 26 elements. Scientists at the USGS used INAA, ICP-MS, and inductively coupled plasma atomic emission spectrometry (ICP-AES) for the determination of 40 elements. Certified, reference, and information values were assigned according to the criteria described in detail by May et al. (2000). Complete descriptions of the collection, preparation, material analyses, data analysis, and certification of SRM 1575a Pine Needles are presented in this report.

Prior to release of SRM 1575a Pine Needles, this material was used as the test material for an international interlaboratory comparison exercise for the determination of element content. This round robin was conducted under the auspices of the ASTM Task Group on Nuclear Methods of Chemical Analysis. Each participant received one 6-g portion of SRM 1575a and one 6-g portion of SRM 1547 Peach Leaves for use as a control material. Participants were instructed to report mass fraction values based on the dry mass of the material and were instructed to determine the dry mass by desiccator drying of separate portions over fresh magnesium perchlorate. The two SRMs were shipped to the participants in March of 2002 and participants were asked to send results by the end of August (2002). Fifteen labs from eight countries participated in the study for the determination of element content and one additional laboratory provided results from determinations of two radioisotopes. The results from these laboratories and complete discussion of the study data also are presented in this report.

\section{MATERIAL COLLECTION AND PREPRATION}

The pine needles used to prepare SRM 1575a were collected, dried, and ground by members of 
the Forest Nutrition Cooperative of North Carolina State University. Approximately $70 \mathrm{~kg}$ of pine needles were collected in North Carolina from freshly felled loblolly pine (Pinus taeda) trees of about the same age. The pine needles were coarse-ground to pass through a 2-mm sieve and dried for $48 \mathrm{~h}$ at $70{ }^{\circ} \mathrm{C}$ prior to shipment to NIST. At NIST, the material was jet milled to pass a $100-\mu \mathrm{m}$ sieve and blended over the course of two weeks. The material was radiation sterilized by exposure to ${ }^{60} \mathrm{Co}(2.5 \mathrm{Mrad})$ for $5 \mathrm{~h}$. After irradiation, the material was apportioned into amber bottles containing approximately $50 \mathrm{~g}$ each. The material collected and processed filled about 1300 bottles. Bottles were randomly selected for certification analyses performed by NIST and USGS scientists. Each analyst was provided with six to twelve bottles of SRM 1575a. The bottles used for each analytical method are listed in Table 1. A total of 30 bottles were used for analyses performed by 14 analysts: ten analysts from NIST and four from the USGS Denver, $\mathrm{CO}$.

Table 1. Bottle Numbers Used by Each for Certification Analyses.

\begin{tabular}{|l|l|l|}
\hline Analyst Group & Technique (Elements) & Bottle Numbers \\
\hline \multirow{5}{*}{ IST } & INAA (Na, K, Mn, Cl, Al, & $29,227,260,308,522,739,803,953$, \\
& $\mathrm{Mg}, \mathrm{Ca})$ & $986,1027,1142,1333$ \\
\cline { 2 - 3 } & INAA (As, Ba, Ce, Co, Cr, & $66,227,308,522,606,739,953,1142$, \\
& $\mathrm{Cs}, \mathrm{Fe}, \mathrm{Rb}, \mathrm{Sb}, \mathrm{Sc}, \mathrm{Se}, \mathrm{Th}, \mathrm{Zn})$ & 1333 \\
\cline { 2 - 3 } & RNAA (Cu, Cd) & $66,227,308,739,803,986,1027,1142$, \\
& & 1333 \\
\cline { 2 - 3 } & RNAA (P) & $66,522,606,739,803,865,953,986$, \\
& & 1027,1224 \\
\cline { 2 - 3 } & RNAA (Hg) & $29,66,308,522,606,1142,1224$ \\
\cline { 2 - 3 } & PGAA (B, Cl, K) & $66,227,308,522,739,953,986,1027$ \\
\cline { 2 - 3 } & ICP-MS (Ba, Cd, Ni, Pb) & $83,189,356,472,708,1107$ \\
\cline { 2 - 3 } & CV-IDMS (Hg) & $83,189,356,472,708,1107$ \\
\cline { 2 - 3 } & Freeze-drying (moisture) & $66,227,308,522,739,953$ \\
\hline \multirow{5}{*}{ USGS } & ICP-AES & $491,619,766,824,901,1149,1191,1255$ \\
\cline { 2 - 3 } & ICP-MS & $491,619,766,824,901,1149,1191,1255$ \\
\hline
\end{tabular}

Prior to analysis, each analyst determined the moisture content of the material using separate portions from several different bottles. Two methods were used at NIST to dry portions removed from previously unopened bottles of SRM 1575a:

1.) desiccator drying over fresh $\mathrm{MgClO}_{4}$ for $120 \mathrm{~h}$,

2.) freeze-drying at a condenser temperature of $-50{ }^{\circ} \mathrm{C}$ and a pressure of $1 \mathrm{~Pa}$ using a shelf temperature gradient beginning at $-10^{\circ} \mathrm{C}$ and increasing in $5^{\circ} \mathrm{C}$ increments to a maximum of $+5{ }^{\circ} \mathrm{C}$ over the course of one week.

A summary of the results of drying studies performed at NIST on those previously unopened bottles of SRM 1575a is shown in Table 2. For each method the number of portions (n) is listed together with the average relative mass lost ( \pm 1 standard deviation, $1 \mathrm{~s})$. Results of these two 
drying methods were similar and indicated the moisture content of this material shortly after bottling was approximately $2.84 \% \pm 0.17 \%$ (the average value $\pm 1 \mathrm{~s}$, for seventeen portions).

The value for moisture content will change with time, depending upon storage and local laboratory conditions. Pelletized portions of SRM 1575a stored for nine months in sealed polyethylene bags placed in plastic Petri dishes gained about $2.9 \%$ mass due to absorption of moisture. Other analysts using portions of SRM 1575a removed from previously opened bottles found that the moisture content of SRM 1575a had increased from approximately $2.8 \%$ (average for five portions with $1 \mathrm{~s}$ of $0.1 \%$ ) to $3.05 \%$ (average for 8 portions with $1 \mathrm{~s}$ of $0.01 \%$ ) and others found a change from $3.0 \%$ (average for six portions with $1 \mathrm{~s}=0.2 \%$ ) to $3.6 \%$ (average for six portions with $1 \mathrm{~s}=0.2 \%$ ). See Table 2 . It is recommended that analysts determine the moisture content on separate individual portions from each bottle, for each use.

Table 2. Results of Initial Drying Study on Bottles of SRM 1575a

\begin{tabular}{|c|c|c|}
\hline Technique & $\mathbf{n}$ & $\begin{array}{l}\text { Moisture Content of } \\
\text { Unopened Bottles }\end{array}$ \\
\hline Freeze-Drying & 6 & $2.76 \% \pm 0.04 \%$ \\
\hline Desiccator Drying $\left(\mathrm{MgClO}_{4}\right)$ & 5 & $2.77 \% \pm 0.11 \%$ \\
\hline \multirow[t]{2}{*}{ Desiccator Drying $\left(\mathrm{MgClO}_{4}\right)$} & 6 & $2.98 \% \pm 0.21 \%$ \\
\hline & 17 & $2.84 \% \pm 0.17 \%$ Average \\
\hline Technique & $\mathbf{n}$ & $\begin{array}{c}\text { Moisture Content of } \\
\text { Previously Opened Bottles }\end{array}$ \\
\hline Desiccator Drying $\left(\mathrm{CaSO}_{4}\right)$ & 8 & $\begin{array}{c}3.05 \% \pm 0.01 \% \\
\text { (previously opened bottles) }\end{array}$ \\
\hline Desiccator Drying $\left(\mathrm{MgClO}_{4}\right)$ & 6 & $\begin{array}{c}3.6 \% \pm 0.2 \% \\
\text { (previously opened bottles) }\end{array}$ \\
\hline
\end{tabular}

\section{EXPERIMENTAL PROCEDURES}

\section{Inductively Coupled Plasma-Mass Spectrometry (ICP-MS) at NIST}

In preparation for ICP-MS, one 0.5-g portion from each of six bottles of SRM 1575a Pine Needles and two 0.5-g portions of SRM 1547 Peach Leaves were weighed into individual microwave cells. Then, $5 \mathrm{~mL}$ of $\mathrm{HNO}_{3}$ and $1 \mathrm{~mL}$ of $\mathrm{HF}$ were added to each cell. Samples were digested in a microwave oven using an eight-step program in which the power was increased from $250 \mathrm{~W}$ to $550 \mathrm{~W}$ over the course of $40 \mathrm{~min}$. The temperature in the cells ranged from $80{ }^{\circ} \mathrm{C}$ up to but not exceeding $90{ }^{\circ} \mathrm{C}$. Each digest was quantitatively transferred to a pre-weighed polyethylene bottle and diluted to a total mass of $50 \mathrm{~g}$ after the addition of an internal standard 
consisting of $80 \mu \mathrm{g}$ of $\mathrm{Rh}$. From each diluted digest, $25 \mathrm{~g}$ were transferred to another polyethylene bottle. One gram of a spike solution containing $0.991 \mu \mathrm{g} / \mathrm{g} \mathrm{Ni}, 0.247 \mu \mathrm{g} / \mathrm{g} \mathrm{Cd}, 0.832$ $\mu \mathrm{g} / \mathrm{g} \mathrm{Ba}$, and $0.486 \mu \mathrm{g} / \mathrm{g} \mathrm{Pb}$ was added to each.

Prior to the quantitative determination of the elements of interest, an ICP-MS semi-quantitative analysis was performed on un-spiked solutions of digested SRM 1575a and SRM 1547. These results were used to assess the presence or absence of interferences, and to determine the optimum concentrations for the spike. Molecular ${ }^{44} \mathrm{Ca}^{16} \mathrm{O}$ was found to interfere with the measurement of ${ }^{60} \mathrm{Ni}$, the isotope chosen for the quantification of $\mathrm{Ni}$. A solution of $100 \mu \mathrm{g} / \mathrm{g} \mathrm{Ca}$ was analyzed with the samples and the ratio of the intensities at masses 60 and 43 was calculated. This ratio was used to correct the measured intensity at mass 60 to obtain the intensity from ${ }^{60} \mathrm{Ni}$. Similarly, ${ }^{95} \mathrm{Mo} \mathrm{o}^{16} \mathrm{O}$ interfered with the determination of ${ }^{111} \mathrm{Cd}$, the isotope used for quantification of $\mathrm{Cd}$. A solution containing $50 \mu \mathrm{g} / \mathrm{g}$ Mo was analyzed with the samples and the ratio of the intensities of masses 111 and 97 was calculated. This ratio was used to correct the measured intensity at 111 , to account for this interference in determining the mass fraction of $\mathrm{Cd}$. No spectral interferences were found for the isotopes used to quantify $\mathrm{Ba}$ or $\mathrm{Pb}$. Blanks were included in the analysis scheme and element mass fraction values were corrected for any amounts present in the blanks. Blank corrections were required for $\mathrm{Ni}, \mathrm{Ba}, \mathrm{Cd}$, and $\mathrm{Pb}$.

\section{Cold Vapor-Isotope Dilution Mass Spectrometry (CV-IDMS) at NIST}

Analysis of $\mathrm{Hg}$ was performed by CV-IDMS of samples prepared using a Carius tube sample digestion. This sample decomposition method has been described in detail elsewhere (Long, et al., 2002) and a brief description is included here. Approximately $0.25 \mathrm{~g}$ of sample from each bottle was weighed into a cleaned Carius tube and spiked with a weighed aliquot of ${ }^{201} \mathrm{Hg}$ followed by the addition of $5 \mathrm{~mL}$ of high-purity $\mathrm{HNO}_{3}$. Each vessel was flame-sealed, placed in a steel cylinder along with $20 \mathrm{~g}$ of solid $\mathrm{CO}_{2}$ for external pressurization, and heated in a convection oven at $240{ }^{\circ} \mathrm{C}$ for $12 \mathrm{~h}$. After cooling to room temperature, each vessel was depressurized using a high-temperature flame, the contents transferred to polypropylene centrifuge tubes, and diluted to a concentration of approximately $0.25 \mathrm{ng} / \mathrm{g} \mathrm{Hg}$. The tubes were stored at $4{ }^{\circ} \mathrm{C}$ overnight to allow degassing of $\mathrm{NO}_{2}$ and $\mathrm{CO}_{2}$. Analyses were performed within $24 \mathrm{~h}$ using cold vapor $\mathrm{Hg}$ generation followed by ICP-MS isotope ratio measurements.

This CV-IDMS method has been described in detail elsewhere (Christopher, et al., 2001) and a brief description is included here. The $\mathrm{Hg}$ vapor was generated using a $10 \%$ (mass/volume) $\mathrm{SnCl}_{2}$ in 7\% (volume fraction) $\mathrm{HCl}$ reductant, and separated from the liquid phase using a commercially available reaction separator cell. The vapor was transferred to an ICP-MS system using 100 $\mathrm{mL} / \mathrm{min}$ of $\mathrm{Ar}_{(\mathrm{g})}$. The gas stream was mixed with the plasma injector gas stream using a plastic $\mathrm{T}$ piece. The ICP was operated in a dry plasma mode. The ${ }^{201} \mathrm{Hg}$ and ${ }^{202} \mathrm{Hg}$ isotopes were monitored in a pulse counting, Time-Resolved-Analysis mode to recover the individual ion count rates. Background corrected ratios were calculated from the isotope-time profiles. Instrument mass discrimination was measured by generation of $\mathrm{Hg}$ vapor from an isotopic calibration standard. The mass discrimination factor was close to unity during the measurement period 
owing to the high mass of the isotopes and the lens settings used. The ${ }^{201} \mathrm{Hg}$ isotopic spike solution was calibrated by reverse isotope dilution using a high-purity primary standard, SRM $1641 \mathrm{~d}$ Mercury in Water. Two separate stock solutions were prepared by serial dilution of the standard. Results of CV ICP-MS showed that the spike contained $0.5702 \mathrm{nmol} / \mathrm{g} \mathrm{Hg}( \pm 0.095 \%$, 1s). Results for samples were corrected for $42 \mathrm{pg}$ of $\mathrm{Hg}$ in the procedural blank.

\section{Instrumental Neutron Activation Analysis (INAA) at NIST}

In preparation for INAA, one portion weighing between $200 \mathrm{mg}$ and $250 \mathrm{mg}$ from each bottle of SRM 1575a was formed into a disk-shaped pellet using a commercially available stainless steel die and hydraulic press. Each disk was doubly encapsulated in bags formed from acid-washed polyethylene film. Element standards consisted of filter papers onto which solutions containing a known amount of the analyte of interest had been deposited and dried. Two portions each of SRM 1547 Peach Leaves and SRM 1575 Pine Needles were included in the analysis for the purpose of quality control. These quality control SRMs were prepared and packaged in the same manner as the portions of SRM 1575a.

For analysis of short-lived products of neutron irradiation, one sample or control SRM or element standard was irradiated individually for $60 \mathrm{~s}$ in the NIST reactor using neutron irradiation tube facility RT-4, which exposed the sample, or sample and standard, to a thermal neutron fluence rate of $3.5 \times 10^{13} \mathrm{~cm}^{-2} \cdot \mathrm{s}^{-1}$. After irradiation, the sample, control, or standard was removed from the irradiation container and polyethylene bag and repackaged in clean (un-irradiated) polyethylene film. Gamma spectrometry was performed on each using a system that consisted of a germanium detector, $16 \mathrm{~K}$ channel, fixed conversion time, analog-to-digital converter linked to a multichannel analyzer. Gamma radiations were collected for $5 \mathrm{~min}$, after a decay time of $5 \mathrm{~min}$, at a distance of $20 \mathrm{~cm}$ from the end of the detector for the determination of $\mathrm{Al}, \mathrm{Ca}$, and $\mathrm{Mg}$. Using the same detector and geometry, gamma radiations were collected again for $5 \mathrm{~min}$, after 15 min of decay, for the determination of $\mathrm{Cl}$, and for a third time for $1 \mathrm{~h}$, after $1 \mathrm{~h}$ to $5 \mathrm{~h}$ of decay for the determination of $\mathrm{Na}, \mathrm{K}$, and $\mathrm{Mn}$. Data reduction was accomplished using commercially available software to determine peak areas and to calculate the activity at the end of irradiation. Element mass fraction values were calculated based on comparison with standards.

For determination of long-lived products of neutron irradiation, separate 200-mg portions of SRM 1575a and control SRMs were prepared and packaged in the same manner. Element standards consisted of either pure metal foils of known mass or filter papers onto which solutions containing known amounts of the elements of interest had been deposited. All SRMs and standards were placed in one of two polyethylene irradiation containers. Iron foils were included in the top and bottom of the irradiation vessel to monitor any differences in neutron fluence over the length of the container. Each container was subjected to a neutron fluence rate of $3.5 \times 10^{13} \mathrm{~cm}^{-2} \mathrm{~s}^{-1}$ for $3 \mathrm{~h}$. Halfway through the neutron irradiation, each container was inverted end-over-end and then reinserted into the reactor. This procedure serves to minimize differences in neutron exposure among the samples and standards due to a linear drop off of the neutron 
fluence rate with distance from the reactor core. All irradiated samples and standards were allowed to decay for $4 \mathrm{~d}$ to $5 \mathrm{~d}$ to eliminate or decrease the activity from short-lived isotopes. Then, each portion was removed from the irradiation vessel and from the irradiated polyethylene bags and placed in another polyethylene bag for gamma spectroscopy. Gamma-ray spectroscopy was performed using a germanium detector ( $40 \%$ efficiency relative to a standardsized $\mathrm{NaI}$ crystal) and associated electronics. For the analysis of As, samples, standards, and controls were counted individually on the germanium detection system for $2 \mathrm{~h}$ to $8 \mathrm{~h}$. After additional decay times of two to three weeks, each individual sample, control, or standard was counted for a minimum of $8 \mathrm{~h}$ and as long as $24 \mathrm{~h}$ for the analysis of $\mathrm{Ba}, \mathrm{Ce}, \mathrm{Co}, \mathrm{Cr}, \mathrm{Cs}, \mathrm{Fe}, \mathrm{Rb}$, $\mathrm{Sb}, \mathrm{Sc}, \mathrm{Se}, \mathrm{Th}$, and $\mathrm{Zn}$. Quantification was based on comparison with elemental standards. Count rates for the Fe fluence-rate monitors, corrected for decay time and mass differences, agreed within $0.5 \%$, indicating that the two containers were exposed to the same neutron irradiation dose.

\section{Prompt Gamma-Ray Activation Analysis (PGAA) at NIST}

For PGAA, one portion weighing between $740 \mathrm{mg}$ and $760 \mathrm{mg}$ was removed from each of eight bottles. Each portion was formed into a disk using a commercially available stainless steel die and hydraulic press, and each disk was packaged in a bag formed from Teflon film. Two portions of SRM 1547 were prepared in the same manner and included for the purpose of quality control. Standards consisted of filter papers onto which solutions containing known amounts of the elements of interest had been deposited. The filter papers were formed into disks and packaged in bags formed from Teflon film so that the geometry of the samples and standards was identical. Each disk of the SRM was simultaneously irradiated and counted for $8 \mathrm{~h}$ to $24 \mathrm{~h}$, and standards for $0.5 \mathrm{~h}$ to $1 \mathrm{~h}$, in the new thermal neutron PGAA instrument at vertical beam tube VT-5. A Ti foil was irradiated before and after each sample to monitor any fluctuations in the neutron fluence rate of VT-5. Over the two-week interval required for this analysis, results of the Ti foil monitor irradiations showed that any variations in neutron fluence rate were $\leq 0.9 \%$. Quantification was based on comparison with elemental standards. All data were corrected for the effects of the pile up of pulses at higher count rates. Results for B were corrected for the presence of this element in the background which was equivalent to $0.7 \mu \mathrm{g}$ of $\mathrm{B}$. The $\mathrm{H}$ content of the standards and the samples were nearly identical so that no corrections for neutron scattering were required.

\section{Radiochemical Neutron Activation Analysis (RNAA) for Cu and Cd at NIST}

Sample, control, and standard preparation were the same for RNAA as described for INAA at NIST. Two portions of SRM 1547 Peach Leaves and two portions of SRM 1570a Trace Elements in Spinach Leaves were included as control materials. The portions of all SRMs and element standards were placed in one of two polyethylene irradiation containers or "rabbits". Iron foils were included in the top and bottom of each rabbit to monitor any differences in neutron fluence over the length of the rabbit and between rabbits. Each rabbit was subjected to a neutron fluence rate of $3.5 \times 10^{13} \mathrm{~cm}^{-2} \mathrm{~s}^{-1}$ for $2 \mathrm{~h}$. Halfway through the neutron irradiation, each rabbit was inverted end-over-end and then reinserted into the reactor to minimize differences in 
neutron exposure among the samples and standards.

This RNAA method has been described in detail elsewhere (Greenberg, 1986) and a brief description is included here. After a decay time of $52 \mathrm{~h}$ to $54 \mathrm{~h}$, each portion was removed from the irradiation container and from the polyethylene bags, and placed in a Teflon beaker containing $10 \mathrm{~mL}$ of concentrated $\mathrm{HNO}_{3}, 10 \mathrm{~mL}$ of $\mathrm{H}_{2} \mathrm{O}$, and $0.1 \mathrm{~mL}$ of a carrier solution. The carrier solution contained $5 \mathrm{mg} / \mathrm{mL} \mathrm{Cu}$ and $5 \mathrm{mg} / \mathrm{mL} \mathrm{Cd}$. Each Teflon beaker was placed on a hot plate with a surface temperature of $150{ }^{\circ} \mathrm{C}$ to $200{ }^{\circ} \mathrm{C}$ until the volumes were reduced to approximately $0.5 \mathrm{~mL}$. An additional $10 \mathrm{~mL}$ of $\mathrm{HNO}_{3}$ and $10 \mathrm{~mL}$ of $\mathrm{HClO}_{4}$ were then added to each beaker and the beakers were covered with Teflon lids. After $1 \mathrm{~h}$, the lids were removed and the surface temperature of the hot plate increased to approximately $180{ }^{\circ} \mathrm{C}$ to $220{ }^{\circ} \mathrm{C}$. Beakers were removed from the hot plate when the volumes were reduced to approximately $0.5 \mathrm{~mL}$. Again, 10 $\mathrm{mL}$ of $\mathrm{HNO}_{3}$ and $10 \mathrm{~mL}$ of $\mathrm{HClO}_{4}$ were added to each beaker. The beakers were covered and placed on a hot plate with a surface temperature of about $120{ }^{\circ} \mathrm{C}$ overnight. The following morning, the lids were removed and the surface temperature of the hot plate was increased to a temperature between $180{ }^{\circ} \mathrm{C}$ and $220^{\circ} \mathrm{C}$. After approximately $1 \mathrm{~h}, 1 \mathrm{~mL}$ of $\mathrm{HF}$ was added to each sample or standard. When volumes were reduced to $0.5 \mathrm{~mL}$ the beakers were removed from the hot plate.

Radiochemical separations consisted of adding $10 \mathrm{~mL}$ of $1 \mathrm{~mol} / \mathrm{L} \mathrm{HNO}_{3}$ to each $0.5 \mathrm{~mL}$ digest and adjusting the $\mathrm{pH}$ to a value between 1.5 and 1.7. The diluted digest was added to a separatory funnel. The $\mathrm{Cu}$ and $\mathrm{Cd}$ were extracted with one $25 \mathrm{~mL}$ portion followed by one $5 \mathrm{~mL}$ portion of a solution containing $2 \mathrm{~g} / \mathrm{L}$ of zinc diethyldithiocarbamate $\left[\mathrm{Zn}(\mathrm{DDC})_{2}\right]$ in chloroform. The $\mathrm{Zn}(\mathrm{DDC})_{2}$ layer was drained into a second separatory funnel containing $25 \mathrm{~mL}$ of $2.5 \mathrm{~mol} / \mathrm{L} \mathrm{HCl}$. This funnel was shaken for $30 \mathrm{~s}$ to back extract the $\mathrm{Cd}$ into the aqueous layer. The lower organic layer containing $\mathrm{Cu}$ was drained into a high-density polyethylene (HDPE) bottle and the upper aqueous layer containing $\mathrm{Cd}$ was transferred to another HDPE bottle. Gamma-ray spectroscopy was performed on each separated fraction using a germanium detector and associated electronics. For the assay of $\mathrm{Cu}$, gamma radiations were collected for $0.5 \mathrm{~h}$ to $2 \mathrm{~h}$. For the assay of $\mathrm{Cd}$, gamma radiation was collected for $2 \mathrm{~h}$ to $8 \mathrm{~h}$ after allowing $24 \mathrm{~h}$ for the ${ }^{115} \mathrm{Cd}$ (half-life, $\mathrm{t}_{1 / 2}=53.4$ $\mathrm{h})$ and ${ }^{115} \mathrm{In}\left(\mathrm{t}_{1 / 2}=4.49 \mathrm{~h}\right)$ isotopes to reach equilibrium. Quantification was based on comparison with standards. Count rates for the Fe fluence-rate monitors, corrected for decay time and mass differences, agreed within $2 \%$, indicating that the two containers experienced the same neutron dose.

\section{Radiochemical Neutron Activation Analysis (RNAA) for P at NIST}

Standards were prepared by depositing solutions containing known amounts of P onto $40 \mathrm{mg}$ pieces of aluminum foil, which were dried by heating under an infrared lamp. These were packaged in bags formed from clean polyethylene film. Sample and control SRMs were prepared and packaged as described for INAA. Samples, controls, and standards were subjected to a neutron fluence rate of $2.7 \times 10^{13} \mathrm{~cm}^{-2} \mathrm{~s}^{-1}$ for $5 \mathrm{~min}$ and were allowed to decay for approximately one week prior to radiochemical separation. Zinc foils were included in each irradiation container 
to monitor any differences in the neutron exposure within a container and among different containers.

Samples or controls were placed in beakers containing $7.02 \mathrm{mg}$ of $\mathrm{P}$ (non-radioactive carrier), $10 \mathrm{~mL}$ concentrated $\mathrm{HNO}_{3}$, and $10 \mathrm{~mL} \mathrm{H}_{2} \mathrm{O}$, covered, and heated for about $16 \mathrm{~h}$ and then allowed to evaporate to near dryness. This procedure was followed by heating in covered beakers with $10 \mathrm{~mL}$ of $\mathrm{HNO}_{3}, 10 \mathrm{~mL}$ of $\mathrm{HClO}_{4}$, and 10 drops of $\mathrm{HF}$ for $16 \mathrm{~h}$, followed by evaporation to near dryness. Standards were subjected to a similar digestion procedure that also included the addition of $7 \mathrm{~mL}$ of $\mathrm{HCl}$ in the initial step. The residue from each was dissolved in $10 \mathrm{~mL}$ of $\mathrm{HNO}_{3}$ and 30 $\mathrm{mL}$ of $\mathrm{H}_{2} \mathrm{O}$, and the standards were filtered to remove any insoluble material. To each sample, control or standard, $5 \mathrm{~g}$ of $\mathrm{NH}_{4} \mathrm{NO}_{3}$ and $20 \mathrm{~mL}$ of a solution containing $10 \%$ (mass/volume) $\mathrm{NH}_{4} \mathrm{MoO}_{3}$ were added to precipitate $\left(\mathrm{NH}_{4}\right)_{3} \mathrm{PO}_{4} \cdot 12 \mathrm{MoO}_{3}$. The precipitates were collected, washed twice with $15 \mathrm{~mL}$ of $\mathrm{H}_{2} \mathrm{O}$, and then dissolved in $10 \mathrm{~mL}$ of $\mathrm{NH}_{4} \mathrm{OH}$. To each were added $20 \mathrm{~mL}$ of $\mathrm{H}_{2} \mathrm{O}, 10 \mathrm{~mL}$ of $20 \%$ (mass/volume) $\mathrm{NH}_{4} \mathrm{Cl}$ and $15 \mathrm{~mL}$ of a magnesia reagent to precipitate $\mathrm{MgNH}_{4} \mathrm{PO}_{4}$ overnight. The precipitate was collected, washed, dried, and transferred to a planchet. Each sample, standard and control was counted using a $\square$ proportional counter. After counting, the precipitate was transferred to a crucible and heated at $650{ }^{\circ} \mathrm{C}$ for at least $1 \mathrm{~h}$ to convert the compound to $\mathrm{Mg}_{2} \mathrm{P}_{2} \mathrm{O}_{7}$. The yields were determined gravimetrically from the masses of $\mathrm{MgNH}_{4} \mathrm{PO}_{4}$ and again from the masses of $\mathrm{Mg}_{2} \mathrm{P}_{2} \mathrm{O}_{7}$.

Radiochemical purity was determined by both gamma-ray screening and by $\square$ analysis of activity as a function of time over the course of four half-lives. Count rates were corrected for the effects of self-absorption of $\square$ particles in the precipitate. Mass fractions were determined using decay-corrected count rates based on comparison with standards.

\section{Radiochemical Neutron Activation Analysis (RNAA) for Hg at NIST}

Portions of SRM 1575a weighing from $160 \mathrm{mg}$ to $250 \mathrm{mg}$ were removed from the bottles and flame-sealed in quartz vials. Control materials were prepared in the same manner. Standards were prepared by depositing solutions containing known amounts of $\mathrm{Hg}$ onto cysteine-impregnated filter paper. The filter papers were dried at room temperature and encapsulated in quartz vials. The standards, samples, and controls were exposed to a neutron flux of $7.7 \times 10^{13} \mathrm{~cm}^{-2} \cdot \mathrm{s}^{-1}$ for $6 \mathrm{~h}$.

After irradiation, the short-lived activities in the samples were allowed to decay before they were processed radiochemically. Each quartz vial was rinsed sequentially in $\mathrm{HNO}_{3}$ and water, frozen in liquid nitrogen, wrapped in tissue, and crushed. In a quartz combustion tube, the package was burned in an unglazed porcelain boat with about $50 \mathrm{mg}$ of $\mathrm{HgO}$ carrier. The sample and tissue were slowly ignited with a hand torch at an airflow of $100 \mathrm{~mL} / \mathrm{min}$ and the oxidation completed in an oxygen flow of $100 \mathrm{~mL} / \mathrm{min}$ for $10 \mathrm{~min}$ in a $700{ }^{\circ} \mathrm{C}$ furnace. The products of combustion were trapped at liquid nitrogen temperature, rinsed into a polyethylene bottle with $5 \mathrm{~mL}$ of $\mathrm{HNO}_{3}$ and diluted to $50 \mathrm{~mL}$ for preliminary gamma assay. After adding $1 \mathrm{mg}$ of Se holdback carrier, the solution was evaporated, taken up in $100 \mathrm{~mL}$ of hot $0.15 \mathrm{~mol} / \mathrm{L} \mathrm{HNO}_{3}$, and mercury periodate precipitated with $1.0 \mathrm{~g}$ of $\mathrm{Na}_{3} \mathrm{H}_{2} \mathrm{IO}_{6}$. After digestion, the precipitate was collected, washed, and 
mounted in a Petri dish for gamma spectrometry. Yields were determined based on the mass of dried $\mathrm{Hg}_{5}\left(\mathrm{IO}_{6}\right)_{2}$, and mass fractions of $\mathrm{Hg}$ were determined based on comparison with standards.

Inductively Coupled Plasma Mass Spectrometry (ICP-MS) at the USGS

This procedure has been described in detail in U.S. Geological Survey Open File Report 02-223-I and a brief summary is included here. Samples and control materials (including SRM 1547 Peach Leaves) were decomposed using a mixture of $\mathrm{HCl}, \mathrm{HNO}_{3}, \mathrm{HClO}_{4}$, and $\mathrm{HF}$ at low temperatures, brought to dryness, and then dissolved using $1 \mathrm{~mL}$ of $\mathrm{HClO}_{4}$ and two drops of $\mathrm{H}_{2} \mathrm{O}_{2}$. Each digest was diluted with $19 \mathrm{~mL}$ of $1 \%$ (volume fraction) $\mathrm{HNO}_{3}$, heated for $30 \mathrm{~min}$, and further diluted $1: 10$ with $1 \%$ (volume fraction) $\mathrm{HNO}_{3}$. Internal standards containing known amounts of $\mathrm{Li}, \mathrm{Rh}$, and $\mathrm{Ir}$ in $1 \% \mathrm{HNO}_{3}$ were added to each sample solution prior to analysis. A dual detector calibration and auto-lens adjustment were performed according to manufacturer's recommendations. Two multi-element solutions were used for calibration.

\section{Inductively Coupled Plasma Atomic Emission Spectrometry (ICP-AES) at USGS}

This procedure has been described in detail in U.S. Geological Survey Open File Report 02-223-G and a brief summary is included here. One 200-mg portion of each sample and control material (SRM 1547 Peach Leaves) was added to a Teflon vessel together with an internal standard consisting of $50 \mu \mathrm{g} \mathrm{Lu}$ in $\mathrm{HCl}$. Samples and control materials were decomposed using a mixture of $\mathrm{HCl}, \mathrm{HNO}_{3}, \mathrm{HClO}_{4}$, and $\mathrm{HF}$ at low temperatures and evaporated to dryness. The dried samples were dissolved in $1 \mathrm{~mL}$ of aqua regia and $9 \mathrm{~mL}$ of $1 \%$ (volume fraction) $\mathrm{HNO}_{3}$. The ICP-AES instrument was calibrated prior to sample analysis using several single and multielement standard solutions. The digested samples were aspirated into the ICP-AES discharge where the elemental emission signals were measured simultaneously for all elements determined. Method blanks were included, and blank subtractions performed where necessary. Inter-element correction factors and background corrections were applied using commercially available software.

\section{RESULTS AND DISCUSSION}

\section{Quality Assurance}

All analysts from NIST and the USGS included portions of either SRM 1575 Pine Needles or SRM 1547 Peach Leaves or both in the analysis scheme for the purpose of quality assurance. Portions of SRM 1570a were included for analyses of $\mathrm{Cu}$ and $\mathrm{Cd}$ at NIST. Results from these analyses agreed with the certified values within the associated uncertainties for all materials for all elements analyzed at NIST and for most elements analyzed at USGS. In a few cases where data did not agree with certified values for a given element, data for that element were not used to assign values for SRM 1575a Pine Needles. A summary of the results from analyses of SRMs 1575 and 1547 are shown in Table 3. 
Analyses were performed at NIST using INAA, RNAA, PGAA, ICP-MS, and CVIDMS. The results from analyses of individual portions expressed on a dry mass basis are listed in Appendix A. Analyses were performed at USGS Denver using ICP-MS, ICP-AES, and INAA. Selected data from USGS, obtained using methods independent of those used at NIST (i.e., methods other than those used at NIST) were used to calculate certificate values. Results from USGS from analyses of individual portions for data used to calculate certificate values are included in Appendix A. Additional data from USGS were used to confirm NIST values but are not included here. Where two NIST methods were available only those data were used to calculate the certificate values for SRM 1575a. The average values $( \pm 1 \mathrm{~s})$ from each technique and each laboratory that were combined to provide certified values are listed in Table 4.

Material homogeneity was assessed based on results from INAA of 10 to $24200 \mathrm{mg}$ portions analyzed at NIST. These results indicated that SRM 1575a is not homogenous with respect to $\mathrm{Cr}$ content for this sample size. The range of values obtained from analyses of individual portions was $0.3 \mathrm{mg} / \mathrm{kg}$ to $0.5 \mathrm{mg} / \mathrm{kg}$. Results from analyses performed at USGS were similar. No other elements were found to be inhomogeneous at this sample size. 


\section{CERTIFICATION AND DATA ANALYSIS}

Certificate values for SRM 1575a are designated as certified, reference, or information according to the modes defined by May et al. (2000) in NIST SP 260-136. The modes used to provide certified, reference, and information values for this material are described briefly here. The certified value for $\mathrm{Hg}$ is based on results from one primary method (CV-IDMS). Results from RNAA confirm this value but were not included in the calculation to determine the certified value. All other certified values are based on results from two or more critically evaluated independent analytical techniques. A NIST certified value is a value for which NIST has the highest confidence in its accuracy in that all known or suspected sources of bias have been accounted for or investigated. Reference values for this material are based on results obtained from a single NIST analytical method, either INAA or ICPMS. Reference values are noncertified values that are the best estimate of the true values but do not meet NIST criteria for certification. Reference values are provided with associated uncertainties that may not include all sources of uncertainty. Information values were provided for two elements, $\mathrm{Cr}$ and $\mathrm{Ce}$. These are noncertified values with no uncertainty assessed. The information value for $\mathrm{Ce}$ is based on results from one NIST method (INAA). Results from several different techniques indicated that $\mathrm{Cr}$ is distributed inhomogenously when measured in several $200 \mathrm{mg}$ portions. For this reason, a $\mathrm{Cr}$ mass fraction range is given for information purposes and this range is based on results from both NIST and USGS.

Data from two or more techniques were combined to provide the certified values using the method described by Levenson et al. (2000). This method assumes a type B distribution of any bias between the methods. The formulae defined by Levenson et al. that were used to combine these results into a certified mass fraction value (X) and expanded uncertainty (U) are shown here:

1. $X=1 / 2\left(\mathrm{x}_{1}+\mathrm{x}_{2}\right)$ for two values or $1 / 3\left(\mathrm{x}_{1}+\mathrm{x}_{2}+\mathrm{x}_{3}\right)$ for three values

2. $U=\mathrm{k}\left[u(B)^{2}+u(X)^{2}\right]^{0.5}$

3. $u(X)=\left[\mathrm{u}\left(\mathrm{x}_{1}\right)^{2} / 4+\mathrm{u}\left(\mathrm{x}_{2}\right)^{2} / 4\right]^{0.5}$

4. $u(B)=\left|\mathrm{x}_{1}-\mathrm{x}_{2}\right| /\left(2(3)^{0.5}\right)$

In those formulae, $u(B)$ is the standard uncertainty of the combined value assuming a rectangular distribution, and $u(X)$ is the combination of the individual within-method uncertainties of the two methods. These combined mass fraction and uncertainty values are listed as certified values in the last column of Table 4. A copy of the Certificate of Analysis for SRM 1575a Pine Needles is included as Appendix B. 

Table 3. Results from Analyses of SRMs 1575 Pine Needles and 1547 Peach Leaves Included with Analyses of SRM 1575a. Methods are listed in Table 4.

\begin{tabular}{|c|c|c|c|c|c|c|}
\hline \multirow[b]{2}{*}{ Element (units) } & \multicolumn{3}{|c|}{ SRM 1575} & \multicolumn{3}{|c|}{ SRM 1547} \\
\hline & Method 1 & Method 2 & Certificate Values & Method 1 & Method 2 & Certificate Value \\
\hline Al $(\mu \mathrm{g} / \mathrm{g})$ & $603 \pm 20$ & 590 & $545 \pm 30$ & $250 \pm 9$ & 270 & $249 \pm 8$ \\
\hline As $(\mu \mathrm{g} / \mathrm{g})$ & $0.20 \pm 0.02$ & & $0.21 \pm 0.04$ & $0.065 \pm 0.014$ & & $0.060 \pm 0.018$ \\
\hline B $(\mu \mathrm{g} / \mathrm{g})$ & not analyzed & & & $27.8 \pm 1.3$ & & $29 \pm 2$ \\
\hline Ba $(\mu \mathrm{g} / \mathrm{g})$ & $7.4 \pm 0.1$ & not analyzed & & $128 \pm 10$ & $127 \pm 4$ & $124 \pm 4$ \\
\hline$C d(\mu \mathrm{g} / \mathrm{g})$ & See 1570a below & not analyzed & $<0.5$ (non-certified) & $0.032 \pm 0.012$ & $0.026 \pm 0.003$ & $0.026 \pm 0.003$ \\
\hline Ca (\%) & $0.41 \pm 0.02$ & 0.413 & $0.41 \% \pm 0.02 \%$ & $1.57 \pm 0.07$ & 1.63 & $1.56 \% \pm 0.02 \%$ \\
\hline Ce $(\mu \mathrm{g} / \mathrm{g})$ & 0.27 & & 0.4 (non-certified) & $11.3 \pm 0.5$ & & 10 (non-certified) \\
\hline Cl $(\mu \mathrm{g} / \mathrm{g})$ & not analyzed & $293 \pm 31$ & & $354 \pm 11$ & $349 \pm 29$ & $360 \pm 19$ \\
\hline Co $(\mu \mathrm{g} / \mathrm{g})$ & $0.109 \pm 0.003$ & & 0.1 (non-certified) & $0.071 \pm 0.002$ & & 0.07 (non-certified) \\
\hline $\mathrm{Cr}(\mu \mathrm{g} / \mathrm{g})$ & $2.52 \pm 0.15$ & 2.84 & $2.6 \pm 0.2$ & $1.33 \pm 0.09$ & 0.55 & 1 (non-certified) \\
\hline Cs $(\mu \mathrm{g} / \mathrm{g})$ & $0.118 \pm 0.004$ & & & $0.079 \pm 0.003$ & & \\
\hline $\mathrm{Cu}(\mu \mathrm{g} / \mathrm{g})$ & See 1570a below & 2.8 & $3.0 \pm 0.3$ & $3.72 \pm 0.20$ & 3.6 & $3.7 \pm 0.4$ \\
\hline $\mathrm{Fe}(\mu \mathrm{g} / \mathrm{g})$ & $186 \pm 6$ & 190 & $200 \pm 10$ & $224 \pm 6$ & 220 & $218 \pm 14$ \\
\hline $\mathrm{Hg}(\mu \mathrm{g} / \mathrm{g})$ & 0.1415 & & $0.15 \pm 0.05$ & 0.0336 & & $0.031 \pm 0.007$ \\
\hline$K(\%)$ & not analyzed & $0.37 \pm 0.04$ & $0.37 \% \pm 0.02 \%$ & $2.49 \pm 0.07$ & $2.54 \pm 0.11$ & $2.43 \% \pm 0.03 \%$ \\
\hline $\operatorname{Mg}(\%)$ & $0.122 \pm 0.029$ & & & $0.442 \pm 0.016$ & & $0.432 \% \pm 0.008 \%$ \\
\hline $\operatorname{Mn}(\mu \mathrm{g} / \mathrm{g})$ & $692 \pm 21$ & & $675 \pm 15$ & $99 \pm 4$ & & $98 \pm 3$ \\
\hline $\mathrm{Na}(\mu \mathrm{g} / \mathrm{g})$ & $40.1 \pm 3.0$ & & & $25.7 \pm 10$ & & $24 \pm 2$ \\
\hline $\mathrm{Ni}(\mu \mathrm{g} / \mathrm{g})$ & not analyzed & & 3.5 (non-certified) & $0.73 \pm 0.09$ & & $0.69 \pm 0.09$ \\
\hline $\mathbf{P}(\%)$ & $0.110 \pm 0.004$ & 0.117 & $0.12 \% \pm 0.02 \%$ & $0.132 \pm 0.002$ & 0.147 & $0.137 \% \pm 0.007 \%$ \\
\hline $\mathrm{Pb}(\mu \mathrm{g} / \mathrm{g})$ & not analyzed & & $10.8 \pm 0.5$ & $0.87 \pm 0.03$ & & $0.87 \pm 0.03$ \\
\hline $\mathrm{Rb}(\mu \mathrm{g} / \mathrm{g})$ & $11.7 \pm 0.3$ & 11.4 & $11.7 \pm 0.1$ & $20.0 \pm 0.6$ & 19.8 & $19.7 \pm 1.2$ \\
\hline Sc $(\mu \mathrm{g} / \mathrm{g})$ & $0.040 \pm 0.001$ & & 0.03 (non-certified) & $0.044 \pm 0.001$ & & 0.04 (non-certified) \\
\hline Se $\quad(\mu \mathrm{g} / \mathrm{g})$ & $0.061 \pm 0.027$ & & & $0.117 \pm 0.004$ & & $0.120 \pm 0.009$ \\
\hline \multirow[t]{2}{*}{$\mathrm{Zn}(\mu \mathrm{g} / \mathrm{g})$} & $65 \pm 10$ & 60.3 & & $18.3 \pm 1.3$ & 18.7 & $17.9 \pm 0.4$ \\
\hline & \multicolumn{3}{|l|}{ SRM 1570a } & & & \\
\hline Element (units) & Method 1 & & Certificate Values & & & \\
\hline $\mathrm{Cu}(\mu \mathrm{g} / \mathrm{g})$ & $12.5 \pm 0.6$ & & $12.2 \pm 0.6$ & & & \\
\hline Cd $(\mu \mathrm{g} / \mathrm{g})$ & $2.86 \pm 0.26$ & & $2.89 \pm 0.07$ & & & \\
\hline
\end{tabular}


Table 4. Average Mass Fraction Values Used to Provide Certificate Values for SRM 1575a Pine Needles.

\begin{tabular}{|c|c|c|c|c|c|c|c|}
\hline Element & Method 1 & Method/Lab & Method 2 & Method/Lab & Method 3 & Method/Lab & Certified Value \\
\hline Al $(\mu \mathrm{g} / \mathrm{g})$ & $575 \pm 16$ & INAA/NIST & $589 \pm 29$ & ICPAES/USGS & & & $580 \pm 30$ \\
\hline Ba $(\mu \mathrm{g} / \mathrm{g})$ & $5.96 \pm 0.45$ & INAA/NIST & $6.06 \pm 0.43$ & ICPMS/NIST & & & $6.0 \pm 0.2$ \\
\hline$C d(\mu g / g)$ & $0.233 \pm 0.009$ & RNAA/NIST & $0.234 \pm 0.003$ & ICPMS/NIST & & & $0.233 \pm 0.004$ \\
\hline Ca $(\%)$ & $0.248 \pm 0.007$ & INAA/NIST & $0.250 \pm 0.013$ & ICPMS/USGS & $0.258 \pm 0.012$ & ICPAES/USGS & $0.25 \pm 0.02$ \\
\hline $\mathrm{Cl}(\mu \mathrm{g} / \mathrm{g})$ & $417 \pm 3$ & PGAA/NIST & $425 \pm 8$ & INAA/NIST & & & $421 \pm 7$ \\
\hline $\mathrm{Cu}(\mu \mathrm{g} / \mathrm{g})$ & $2.89 \pm 0.03$ & RNAA/NIST & $2.70 \pm 0.17$ & ICPAES/USGS & & & $2.8 \pm 0.2$ \\
\hline Fe $(\mu \mathrm{g} / \mathrm{g})$ & $45.9 \pm 0.5$ & INAA/NIST & $46.0 \pm 2.3$ & ICPAES/USGS & & & $46 \pm 2$ \\
\hline$K(\%)$ & $0.4137 \pm 0.0037$ & PGAA/NIST & $0.4209 \pm 0.0128$ & INAA/NIST & & & $0.417 \pm 0.007$ \\
\hline $\mathrm{Hg}(\mu \mathrm{g} / \mathrm{g})$ & $0.0399 \pm 0.0004$ & CVIDMS/NIST & $0.0414 \pm 0.0028$ & RNAA/NIST & & & $0.0399 \pm 0.0007$ \\
\hline P (\%) & $0.102 \pm 0.002$ & RNAA/NIST & $0.112 \pm 0.005$ & ICPAES/USGS & & & $0.107 \pm 0.008$ \\
\hline $\mathrm{Rb}(\mu \mathrm{g} / \mathrm{g})$ & $16.55 \pm 0.14$ & INAA/NIST & $16.36 \pm 0.81$ & ICPMS/USGS & & & $16.5 \pm 0.9$ \\
\hline $\operatorname{Zn}(\mu \mathrm{g} / \mathrm{g})$ & $38.0 \pm 0.2$ & INAA/NIST & $37.7 \pm 1.8$ & ICPAES/USGS & & & $38 \pm 2$ \\
\hline & & & & & & & Reference Value \\
\hline As $(\mu \mathrm{g} / \mathrm{g})$ & $38.9 \pm 1.2$ & INAA/NIST & & & & & $0.039 \pm 0.002$ \\
\hline $\mathrm{B}(\mu \mathrm{g} / \mathrm{g})$ & $9.6 \pm 0.2$ & PGAA/NIST & & & & & \\
\hline Cs $(\mu \mathrm{g} / \mathrm{g})$ & $283 \pm 3$ & INAA/NIST & & & & & $0.283 \pm 0.009$ \\
\hline Co $(\mu \mathrm{g} / \mathrm{g})$ & $61.4 \pm 0.8$ & INAA/NIST & & & & & $0.061 \pm 0.002$ \\
\hline $\mathrm{Pb}(\mu \mathrm{g} / \mathrm{g})$ & $0.167 \pm 0.013$ & ICPMS/NIST & & & & & $0.167 \pm 0.015$ \\
\hline $\operatorname{Mg}(\%)$ & $0.106 \pm 0.007$ & INAA/NIST & & & & & $0.106 \pm 0.017$ \\
\hline $\operatorname{Mn}(\mu \mathrm{g} / \mathrm{g})$ & $488 \pm 6$ & INAA/NIST & & & & & $488 \pm 12$ \\
\hline $\mathrm{Ni}(\mu \mathrm{g} / \mathrm{g})$ & $1.47 \pm 0.10$ & ICPMS/NIST & & & & & $1.47 \pm 0.10$ \\
\hline Sc $(\mu \mathrm{g} / \mathrm{g})$ & $0.0101 \pm 0.0002$ & INAA/NIST & & & & & $0.0101 \pm 0.0003$ \\
\hline Se $(\mu \mathrm{g} / \mathrm{g})$ & $0.099 \pm 0.004$ & INAA/NIST & & & & & $0.099 \pm 0.004$ \\
\hline $\mathrm{Na}(\mu \mathrm{g} / \mathrm{g})$ & $63 \pm 2$ & INAA/NIST & & & & & $63 \pm 1$ \\
\hline & & & & & & & $\begin{array}{l}\text { Information } \\
\text { Value }\end{array}$ \\
\hline $\mathrm{Cr}(\mu \mathrm{g} / \mathrm{g})$ & $0.375 \pm 0.065$ & INAA/NIST & $0.32 \pm 0.02$ & ICPAES/USGS & $0.39 \pm 0.03$ & ICPMS/USGS & $0.3-0.5$ \\
\hline Ce $(\mu g / g)$ & $0.114 \pm 0.010$ & INAA/NIST & & & & & 0.11 \\
\hline
\end{tabular}




\section{INTERLABORATORY COMPARISON METHODS}

The ASTM Task Group for Nuclear Methods of Chemical Analysis has sponsored interlaboratory comparison exercises for the last $20 \mathrm{y}$ to provide laboratories with the opportunity to assess their analytical capabilities. Fifteen laboratories participated in this comparison exercise for analysis of inorganic constituents of SRM 1575a Pine Needles and one additional laboratory submitted values for the isotopes ${ }^{232} \mathrm{Th}$ and ${ }^{238} \mathrm{U}$. All participants were provided one bottle containing about $6 \mathrm{~g}$ of SRM 1575a Pine Needles and another containing about $6 \mathrm{~g}$ of SRM 1547 Peach Leaves for use as a control material. The instructions included a request to the laboratories to analyze a minimum of three portions weighing at least $200 \mathrm{mg}$. Analysts were also instructed to determine the material dry mass using three separate portions not used for elemental analysis and to report the results of analysis on a dry-mass basis. The list of participants is included in Appendix C.

When data were received, each lab was assigned (randomly) a number between 1 and 24 for identification purposes. Labs that provided values from more than one analytical technique were given alphabetical additions to the number codes, e.g., Laboratory 13a, 13b, and 13c, or Laboratory $15 \mathrm{a}$ and $15 \mathrm{~b}$. These data were not combined into a single value from that one laboratory, but rather were treated as if they were from separate laboratories. Most participants used INAA to determine element content but a few laboratories provided additional information using other techniques (e.g., RNAA, flame atomic absorption spectrometry [AAS], or graphite furnace AAS) and one lab used ASTM methods. The analytical methods used by each laboratory for each element are listed in Table 5 together with the laboratory number code.

\section{RESULTS OF THE ASTM INTERLABORATORY COMPARISON}

The results from each laboratory are listed in Appendix D identified only by laboratory number code and results for each element are listed in Appendix E. All data from the study participants were compiled and average and standard deviation values were calculated where possible. Values from individual laboratories were then compared with certificate values where available and with the average value from all participants where no certificate value was available. These comparisons were done in the form of z-scores that were calculated according to the following equation:

$$
\text { 5. } \mathrm{z}=\left(\mathrm{x}_{\mathrm{n}}-\mathrm{x}_{\mathrm{ref}}\right) /\left(\mathrm{sx}_{\mathrm{ref}}\right)
$$

where $\mathrm{x}_{\mathrm{n}}$ is the value for the participating laboratory, $10 \%$ was selected as the relative standard deviation $\mathrm{s}$, and $\mathrm{x}_{\mathrm{ref}}$ is either the certificate value or the ASTM average (where no certificate value was available). Outlier rejection was based on $z$-score values $>+3$ or $<-3$, indicating that the reported value differed from the reference value by greater than $30 \%$. After any outliers were identified, the ASTM average was recalculated and the z-scores were re-evaluated so that the

final values listed reflect this iterative approach. Results that were rejected based on this criteria 
have been shaded in the tables in Appendices D and E. Average and z-score values were not calculated in cases where no certificate value was available and the number of values was $\leq 3$. Average and z-scores were not calculated for either $\mathrm{Hf}$ or Au because the range of values was too great, and therefore agreement too poor, to permit meaningful data analysis. Where no statistical analyses were performed, cells in the tables have been filled with diagonal hatch marks.

Table 5. Methods Used by Participants in the ASTM Interlaboratory Comparison Exercise for Determination of Element Content of SRM 1575a Pine Needles

\begin{tabular}{|c|c|c|}
\hline Lab No. & Elements & Methods \\
\hline 2 & ${ }^{232} \mathrm{Th},{ }^{238} \mathrm{U}$ & Radioisotope Analysis \\
\hline 3 & $\begin{array}{l}\mathrm{Al}, \mathrm{Sb}, \mathrm{As}, \mathrm{Ba}, \mathrm{Br}, \mathrm{Ca}, \mathrm{Cd}, \mathrm{Ce}, \mathrm{Cs}, \mathrm{Cl}, \mathrm{Cr} \text {, } \\
\mathrm{Co}, \mathrm{Cu}, \mathrm{F}, \mathrm{Au}, \mathrm{Hf}, \mathrm{Fe}, \mathrm{La}, \mathrm{Mg}, \mathrm{Mn}, \mathrm{Hg} \\
\mathrm{K}, \mathrm{Rb}, \mathrm{Sm}, \mathrm{Sc}, \mathrm{Se}, \mathrm{Na}, \mathrm{Sr}, \mathrm{Th}, \mathrm{Zn}\end{array}$ & INAA \\
\hline 4 & $\mathrm{Br}, \mathrm{Co}, \mathrm{Eu}, \mathrm{Fe}, \mathrm{La}, \mathrm{Rb}, \mathrm{Sm}, \mathrm{Sc}, \mathrm{Se}, \mathrm{Zn}$ & INAA \\
\hline 6 & $\begin{array}{l}\mathrm{Sb}, \mathrm{As}, \mathrm{Ba}, \mathrm{Br}, \mathrm{Ca}, \mathrm{Ce}, \mathrm{Cs}, \mathrm{Cl}, \mathrm{Cr}, \mathrm{Co}, \mathrm{Fe}, \\
\mathrm{La}, \mathrm{Mg}, \mathrm{Mn}, \mathrm{K}, \mathrm{Rb}, \mathrm{Sm}, \mathrm{Sc}, \mathrm{Na}, \mathrm{Th}, \mathrm{Zn}\end{array}$ & INAA \\
\hline 8 & $\begin{array}{l}\mathrm{Al}, \mathrm{Sb}, \mathrm{As}, \mathrm{Ba}, \mathrm{Br}, \mathrm{Ca}, \mathrm{Cs}, \mathrm{Cl}, \mathrm{Cr}, \mathrm{Co}, \mathrm{Eu}, \\
\mathrm{Au}, \mathrm{Fe}, \mathrm{La}, \mathrm{Mg}, \mathrm{Mn}, \mathrm{Ni}, \mathrm{K}, \mathrm{Rb}, \mathrm{Sm}, \mathrm{Sc} \\
\mathrm{Se}, \mathrm{Sr}, \mathrm{Ta}, \mathrm{Th}, \mathrm{U}, \mathrm{V}, \mathrm{Zn}\end{array}$ & INAA \\
\hline 10 & $\mathrm{Co}, \mathrm{Mo}, \mathrm{Rb}, \mathrm{Sc}, \mathrm{U}, \mathrm{Zn}$ & INAA \\
\hline $13 \mathrm{a}$ & $\begin{array}{l}\text { As, Ba, Br, Cs, Cr, Co, Au, Hf, Fe, La, } \\
\text { Mn, P, K, Rb, Sc, Na, Th, Zn }\end{array}$ & $\begin{array}{l}\text { INAA-1 } \\
\text { RNAA (P only) }\end{array}$ \\
\hline $13 b$ & $\begin{array}{l}\mathrm{Sb}, \mathrm{Ba}, \mathrm{Br}, \mathrm{Ce}, \mathrm{Cs}, \mathrm{Cr}, \mathrm{Co}, \mathrm{Hf}, \mathrm{Fe}, \mathrm{La}, \mathrm{K}, \\
\mathrm{Rb}, \mathrm{Sm}, \mathrm{Sc}, \mathrm{Se}, \mathrm{Th}, \mathrm{Yb}, \mathrm{Zn}\end{array}$ & INAA-2 \\
\hline $13 \mathrm{c}$ & $\mathrm{Ca}, \mathrm{Fe}, \mathrm{Mg}, \mathrm{Mn}, \mathrm{K}, \mathrm{Na}, \mathrm{Zn}$ & AAS \\
\hline $15 \mathrm{a}$ & $\mathrm{Br}, \mathrm{Mn}, \mathrm{K}, \mathrm{Na}$ & INAA \\
\hline $15 b$ & $\begin{array}{l}\mathrm{Al}, \mathrm{Ca}, \mathrm{Cd}, \mathrm{Cr}, \mathrm{Co}, \mathrm{Cu}, \mathrm{Fe}, \mathrm{Pb}, \mathrm{Mg}, \mathrm{Mn}, \\
\mathrm{Ni}, \mathrm{K}, \mathrm{Ag}, \mathrm{Na}, \mathrm{Zn}\end{array}$ & FAAS/GFAAS \\
\hline 16 & $\begin{array}{l}\mathrm{Sb}, \mathrm{Ba}, \mathrm{Br}, \mathrm{Ca}, \mathrm{Cd}, \mathrm{Ce}, \mathrm{Cs}, \mathrm{Cr}, \mathrm{Co}, \mathrm{Eu} \\
\mathrm{Au}, \mathrm{Hf}, \mathrm{Fe}, \mathrm{La}, \mathrm{Lu}, \mathrm{Hg}, \mathrm{Ni}, \mathrm{K}, \mathrm{Rb}, \mathrm{Sm}, \mathrm{Sc} \\
\mathrm{Se}, \mathrm{Na}, \mathrm{Sr}, \mathrm{Ta}, \mathrm{Tb}, \mathrm{Th}, \mathrm{Tb}, \mathrm{Zn}\end{array}$ & INAA \\
\hline 17 & $\begin{array}{l}\mathrm{Al}, \mathrm{Sb}, \mathrm{As}, \mathrm{Br}, \mathrm{Ca}, \mathrm{Cs}, \mathrm{Cl}, \mathrm{Cr}, \mathrm{Co}, \mathrm{Fe}, \mathrm{Mg}, \\
\mathrm{Mn}, \mathrm{K}, \mathrm{Rb}, \mathrm{Sc}, \mathrm{Na}, \mathrm{Zn}\end{array}$ & INAA \\
\hline 18 & $\begin{array}{l}\mathrm{Br}, \mathrm{Ca}, \mathrm{Ce}, \mathrm{Co}, \mathrm{Fe}, \mathrm{La}, \mathrm{Nd}, \mathrm{K}, \mathrm{Rb}, \mathrm{Sm}, \mathrm{Sc}, \\
\mathrm{Na}, \mathrm{Tb}, \mathrm{Zn}\end{array}$ & INAA \\
\hline 19 & $\begin{array}{l}\text { As, Ba, Cs, Cr, Co, Fe, La, K, Rb, Sc, Na, } \\
\text { Zn }\end{array}$ & INAA \\
\hline 20 & $\begin{array}{l}\mathrm{Sb}, \mathrm{As}, \mathrm{Ba}, \mathrm{Br}, \mathrm{Ca}, \mathrm{Ce}, \mathrm{Cs}, \mathrm{Cr}, \mathrm{Co}, \mathrm{Eu}, \\
\mathrm{Au}, \mathrm{Hf}, \mathrm{Fe}, \mathrm{La}, \mathrm{Lu}, \mathrm{Hg}, \mathrm{K}, \mathrm{Rb}, \mathrm{Sm}, \mathrm{Sc}, \mathrm{Se}, \\
\mathrm{Na}, \mathrm{Sr}, \mathrm{Ta}, \mathrm{Tb}, \mathrm{Th}, \mathrm{Yb}, \mathrm{Zn}\end{array}$ & INAA \\
\hline
\end{tabular}




\begin{tabular}{|l|l|l|}
\hline 21 & $\mathrm{Br}, \mathrm{Ca}, \mathrm{Cs}, \mathrm{Co}, \mathrm{Fe}, \mathrm{K}, \mathrm{Rb}, \mathrm{Sc}, \mathrm{Na}, \mathrm{Zn}$ & INAA \\
\hline 23 & $\begin{array}{l}\mathrm{Ca}, \mathrm{Cu}, \mathrm{Fe}, \mathrm{Mg}, \mathrm{Mn}, \text { Total Kjeldahl N, P, } \\
\text { K, S, Zn }\end{array}$ & $\begin{array}{l}\text { E-6010 } \\
\text { ASTM\#1402-07 (TKN, P) } \\
\text { ASTM\# 1552-90 (S) }\end{array}$ \\
\hline 24 & $\begin{array}{l}\mathrm{Al}, \mathrm{Sb}, \mathrm{As}, \mathrm{Br}, \mathrm{Ca}, \mathrm{Cl}, \mathrm{La}, \mathrm{Mg}, \mathrm{Mn}, \mathrm{Mo}, \\
\mathrm{Ni}, \mathrm{K}, \mathrm{Sm}, \mathrm{Na}\end{array}$ & INAA \\
\hline
\end{tabular}

A summary of the interlaboratory comparison data is presented in Table 6 together with the certified values. Note that the number of values for each element differed greatly, ranging from 16 values to just one value. Because outlier rejection was based on comparison with the certificate values, the interlaboratory averages calculated after rejection of outliers generally agree better with the certificate values. In all cases, standard deviation values were reduced by outlier rejection. Participants also provided mass fraction values or limits of detection for 23 elements (Au, Br, Eu, F, Ga, Hf, I, In, Ir, La, Mo, total Kjeldahl N, S, Sb, Sm, Sr, Ta, Tb, Th, W, U, and $\mathrm{Yb}$ ) that were not included on the certificate of analysis for SRM 1575a. A summary of these results is shown in Table 7. The number of values for these elements is generally smaller but ranged from 13 values for $\mathrm{Br}$ to a single value for the following eight elements: F, Ga, In, I, Ir, Total Kjeldahl N, S, W. The average values before and after outlier rejection were calculated except in cases where there was only one value, or in cases where agreement among the values was too poor to permit meaningful data analysis.

Nota Bene: Results of analyses from this ASTM interlaboratory comparison exercise are included in this report to provide a complete description of the study results. Any values in this report that are not included on the Certificate of Analysis have not been evaluated for accuracy and should not be used as certificate values. 
Table 6. Results of the ASTM Interlaboratory Comparison Exercise for Determination of Element Content of SRM 1575a Pine Needles Compared with Certificate Mass Fraction Values.

\begin{tabular}{|c|c|c|c|c|c|}
\hline Element (unit) & $\begin{array}{c}\text { Certificate Mass } \\
\text { Fraction Value }\end{array}$ & $\begin{array}{c}\text { Interlaboratory } \\
\text { Average } \pm 1 \mathrm{~s}\end{array}$ & $n$ & $\begin{array}{c}\text { Interlaboratory } \\
\text { (after outlier } \\
\text { rejection) } \\
\text { Average } \pm 1 s\end{array}$ & $n$ \\
\hline Aluminum $(\mu \mathrm{g} / \mathrm{g})$ & $580 \pm 30$ & $583 \pm 128$ & 5 & $533 \pm 69$ & 4 \\
\hline Barium $(\mu \mathrm{g} / \mathrm{g})$ & $6.0 \pm 0.2$ & $6.2 \pm 1.9$ & 8 & $5.4 \pm 0.4$ & 5 \\
\hline Cadmium $(\mu \mathrm{g} / \mathrm{g})$ & $0.233 \pm 0.004$ & $0.208 \pm 0.178$ & 3 & 0.252 & 1 \\
\hline Calcium (\%) & $0.25 \pm 0.02$ & $0.253 \pm 0.072$ & 12 & $0.24 \pm 0.02$ & 10 \\
\hline Chlorine $(\mu \mathrm{g} / \mathrm{g})$ & $421 \pm 7$ & $399 \pm 22$ & 5 & $399 \pm 22$ & 5 \\
\hline Copper $(\mu \mathrm{g} / \mathrm{g})$ & $2.8 \pm 0.2$ & $2.9 \pm 1.0$ & 3 & 3.0 & 1 \\
\hline Iron $(\mu \mathrm{g} / \mathrm{g})$ & $46 \pm 2$ & $56 \pm 42$ & 14 & $46 \pm 3$ & 12 \\
\hline Potassium (\%) & $0.417 \pm 0.007$ & $0.421 \pm 0.529$ & 13 & $0.407 \pm 0.016$ & 12 \\
\hline Mercury $(\mu \mathrm{g} / \mathrm{g})$ & $0.0399 \pm 0.0007$ & $0.024 \pm 0.018$ & 3 & $0.0341 \pm 0.0071$ & 2 \\
\hline Phosphorus (\%) & $0.107 \pm 0.008$ & $0.118 \pm 0.008$ & 2 & $0.118 \pm 0.008$ & 2 \\
\hline Rubidium $(\mu \mathrm{g} / \mathrm{g})$ & $16.5 \pm 0.9$ & $15.1 \pm 4.8$ & 12 & $16.5 \pm 0.7$ & 11 \\
\hline Zinc $(\mu \mathrm{g} / \mathrm{g})$ & $38 \pm 2$ & $37 \pm 5$ & 14 & $36 \pm 4$ & 13 \\
\hline Element (unit) & $\begin{array}{c}\text { Reference Mass } \\
\text { Fraction Value }\end{array}$ & $\begin{array}{c}\text { Interlaboratory } \\
\text { Average } \pm 1 \mathrm{~s}\end{array}$ & $n$ & $\begin{array}{c}\text { Interlaboratory } \\
\text { (after outlier } \\
\text { rejection) } \\
\text { Average } \pm 1 s\end{array}$ & $n$ \\
\hline Arsenic $(\mu \mathrm{g} / \mathrm{g})$ & $0.039 \pm 0.002$ & $0.048 \pm 0.023$ & 8 & $0.040 \pm 0.005$ & 7 \\
\hline Cesium $(\mu \mathrm{g} / \mathrm{g})$ & $0.283 \pm 0.009$ & $0.276 \pm 0.029$ & 10 & $0.284 \pm 0.012$ & 9 \\
\hline Cobalt $(\mu \mathrm{g} / \mathrm{g})$ & $0.061 \pm 0.002$ & $0.101 \pm 0.132$ & 12 & $0.063 \pm 0.007$ & 11 \\
\hline Lead $(\mu \mathrm{g} / \mathrm{g})$ & $0.167 \pm 0.015$ & $0.115 \pm 0.031$ & 1 & no values & 0 \\
\hline Magnesium (\%) & $0.106 \pm 0.017$ & $0.100 \pm 0.018$ & 8 & $0.105 \pm 0.010$ & 7 \\
\hline Manganese $(\mu \mathrm{g} / \mathrm{g})$ & $488 \pm 12$ & $458 \pm 31$ & 8 & $458 \pm 31$ & 8 \\
\hline Nickel $(\mu \mathrm{g} / \mathrm{g})$ & $1.47 \pm 0.10$ & $1.21 \pm 0.27$ & 4 & $1.31 \pm 0.22$ & 3 \\
\hline Scandium $(\mu \mathrm{g} / \mathrm{g})$ & $0.0101 \pm 0.0003$ & $0.018 \pm 0.025$ & 12 & $0.0104 \pm 0.0015$ & 11 \\
\hline Selenium $(\mu \mathrm{g} / \mathrm{g})$ & $0.099 \pm 0.004$ & $0.093 \pm 0.044$ & 6 & $0.118 \pm 0.015$ & 4 \\
\hline Sodium $(\mu \mathrm{g} / \mathrm{g})$ & $63 \pm 1$ & $71 \pm 20$ & 11 & $63 \pm 5$ & 9 \\
\hline Element (unit) & Information Values & $\begin{array}{c}\text { Interlaboratory } \\
\text { Average } \pm 1 \mathrm{~s}\end{array}$ & $n$ & $\begin{array}{l}\text { Interlaboratory } \\
\text { (after rejection of } \\
\text { selected data) } \\
\text { Average } \pm 1 s\end{array}$ & $n$ \\
\hline Chromium $(\mu \mathrm{g} / \mathrm{g})$ & $0.3-0.5$ & $0.502 \pm 0.507$ & 10 & $0.334 \pm 0.039$ & 8 \\
\hline Cerium $(\mu \mathrm{g} / \mathrm{g})$ & 0.11 & $0.208 \pm 0.261$ & 6 & $0.10 \pm 0.02$ & 5 \\
\hline
\end{tabular}


Table 7. Results of the ASTM Interlaboratory Comparison Exercise for Determination of Element Content of SRM 1575a Pine Needles: elements not included on the Certificate of Analysis.

\begin{tabular}{|c|c|c|c|c|c|c|}
\hline Element (units) & Range & $\begin{array}{c}\text { Interlaboratory } \\
\text { Average } \pm 1 \mathrm{~s} \\
\text { or single value } \\
\end{array}$ & $\mathrm{n}^{*}$ & $\begin{array}{c}\text { Range (after } \\
\text { outlier rejection) }\end{array}$ & \begin{tabular}{|c|} 
Interlaboratory (after \\
outlier rejection) \\
Average $\pm 1 \mathrm{~s}$ \\
\end{tabular} & $\mathrm{n}$ \\
\hline Antimony (mg/kg) & $0.0062-0.033$ & $0.015 \pm 0.009$ & 8 & $0.0062-0.0099$ & $0.009 \pm 0.001$ & 4 \\
\hline Bromine $(\mathrm{mg} / \mathrm{kg})$ & $2.10-3.91$ & $2.95 \pm 0.42$ & 13 & $2.10-3.38$ & $2.87 \pm 0.32$ & 12 \\
\hline Europium(mg/kg) & $\begin{array}{c}<0.002-0.0017 \\
(\mathrm{n}=5)\end{array}$ & $\begin{array}{c}0.0014 \pm \\
0.0003 \\
\end{array}$ & 3 & & & \\
\hline Fluorine $(\mathrm{mg} / \mathrm{kg})$ & & 389 & 1 & & & \\
\hline Gallium(mg/kg) & & $<1$ & 1 & & & \\
\hline Gold (mg/kg) & $0.00026-0.0026$ & & 5 & & & \\
\hline Hafnium(mg/kg) & $<0.015-0.12$ & & 5 & & & \\
\hline Indium $(\mathrm{mg} / \mathrm{kg})$ & & $<0.003$ & 1 & & & \\
\hline Iodine $(\mathrm{mg} / \mathrm{kg})$ & & $<1.5$ & 1 & & & \\
\hline Iridium $(\mathrm{mg} / \mathrm{kg})$ & & $<0.0001$ & 1 & & & \\
\hline Lanthanum $(\mathrm{mg} / \mathrm{kg})$ & $0.042-0.39$ & $0.101 \pm 0.106$ & 10 & $0.042-0.066$ & $0.053 \pm 0.008$ & 8 \\
\hline $\begin{array}{l}\text { Molybdenum } \\
(\mathrm{mg} / \mathrm{kg})\end{array}$ & $\begin{array}{c}<0.1-0.0124 \\
(\mathrm{n}=3)\end{array}$ & 0.0124 & 1 & & & \\
\hline $\begin{array}{l}\text { Neodymium } \\
(\mathrm{mg} / \mathrm{kg})\end{array}$ & & 0.0283 & 1 & & & \\
\hline Nitrogen $(\mathrm{TKN}) \%$ & & 1.11 & 1 & & & \\
\hline Samarium(mg/kg) & $0.0059-0.042$ & $0.012 \pm 0.011$ & 9 & $0.0059-0.0090$ & $0.0077 \pm 0.0009$ & 8 \\
\hline Strontium $(\mathrm{mg} / \mathrm{kg})$ & $4.9-8.5$ & $6.8 \pm 1.5$ & 4 & no data rejected & no data rejected & 4 \\
\hline Sulfur(\%) & & 0.102 & 1 & & & \\
\hline Tantalum (mg/kg) & $\begin{array}{c}0.0011-0.0028 \\
<0.005(\mathrm{n}=1)\end{array}$ & $\begin{array}{c}0.0018 \pm \\
0.0009 \\
\end{array}$ & 3 & & & \\
\hline Terbium(mg/kg) & $0.00053,0.008$ & & 2 & & & \\
\hline Thorium(mg/kg) & $0.010-0.205$ & $0.068 \pm 0.090$ & 7 & $0.014-0.018$ & $0.016 \pm 0.001$ & 4 \\
\hline${ }^{232} \mathrm{Th}(\mathrm{mg} / \mathrm{kg})$ & & 0.027 & 1 & & & \\
\hline Tungsten $(\mathrm{mg} / \mathrm{kg})$ & & 0.065 & 1 & & & \\
\hline Uranium (mg/kg) & $\begin{array}{c}0.007-0.012 \\
(<0.04,<0.08) \\
\end{array}$ & $0.087 \pm 0.003$ & 3 & & & \\
\hline${ }^{238} \mathrm{U} \quad(\mathrm{mg} / \mathrm{kg})$ & & 0.0049 & 1 & & & \\
\hline Vanadium (mg/kg) & $<0.08-<0.34$ & & 3 & & & \\
\hline Ytterbium (mg/kg) & $0.002-0.025$ & & 3 & & & \\
\hline
\end{tabular}

*The values included in the average do not include values that were reported as limits of detection. The value for " $n$ " represents the number of laboratories, not number of portions analyzed. 
Nota Bene: Results of analyses from this ASTM interlaboratory comparison exercise are included in this report to provide a complete description of the study results. Any values in this report that are not included on the Certificate of Analysis have not been evaluated for accuracy and should not be used as certificate values. 


\section{References}

Christopher SJ, Long SE, Rearick MS, Fassett JD. Anal. Chem. 73, 2190-2199, 2001

Greenberg RR. Anal. Chem. 58, 2516-2523, 1986.

Levenson MS, Banks DL, Eberhardt KR, Gill LM, Guthrie WF, Liu HK, Vangel MS, Yen JH, Zhang NF, J Res. NIST 105(2000) 571-579.

Long SE, Kelly WR, Anal. Chem. 74, 1477-1483, 2002.

May W, Parris R, Beck C, Fassett J, Greenberg R, Guenther F, Kramer G, Wise S, Gills T, Colbert J, Gettings R, MacDonald B. NIST SP 230-136 "Definitions of Terms and Modes Used at NIST for Value-Assignment of Reference Materials for Chemical Measurements" U.S. Government Printing Office Washington, pp. 12, 2000.

U.S. Geological Survey Open File Report 02-0223-G Analytical Methods for Chemical Analysis of Geological and Other Materials U.S. Geological Survey. Chapter I "The Determination of 40 Elements in Geological Materials by Inductively Coupled PlasmaAtomic Emission Spectrometry." PH Briggs, pp. 18, 2002.

U.S. Geological Survey Open File Report 02-0223-I, Analytical Methods for Chemical Analysis of Geological and Other Materials U.S. Geological Survey, Chapter I "The Determination of 42 Elements in Geological Materials by Inductively Coupled Plasma-Mass Spectrometry." PH Briggs and AL Meier, pp. 14, 2002. 
Appendix A Results of Certification Analyses of Individual Portions of SRM 1575a

Performed at NIST and at USGS Presented by Technique and Laboratory 


\begin{tabular}{|c|c|c|c|c|c|}
\hline \multicolumn{2}{|c|}{ NIST-CVIDMS } & \multicolumn{4}{|l|}{ NIST-ICPMS } \\
\hline Bottle No. & $\mathrm{Hg}(\mathrm{ng} / \mathrm{g})$ & $\mathrm{Ba}(\mu \mathrm{g} / \mathrm{g})$ & $\mathrm{Pb}(\mu \mathrm{g} / \mathrm{g})$ & $\mathrm{Ni}(\mu \mathrm{g} / \mathrm{g})$ & $\mathrm{Cd}(\mu \mathrm{g} / \mathrm{g})$ \\
\hline 83 & & 5.78 & 0.157 & 1.478 & 0.235 \\
\hline 189 & 40.35 & 5.82 & 0.156 & 1.539 & 0.232 \\
\hline 356 & 40.21 & 6.84 & 0.189 & 1.500 & 0.233 \\
\hline 472 & 40.11 & 5.79 & 0.161 & 1.430 & 0.240 \\
\hline 708 & 39.46 & 5.82 & 0.164 & 1.587 & 0.233 \\
\hline 1107 & 39.52 & 6.29 & 0.173 & 1.313 & 0.232 \\
\hline average & 39.9 & 6.06 & 0.167 & 1.475 & 0.234 \\
\hline std dev & 0.4 & 0.43 & 0.013 & 0.095 & 0.003 \\
\hline $\mathrm{n}$ & 5 & 6 & 6 & 6 & 6 \\
\hline
\end{tabular}

\begin{tabular}{|c|c|c|c|c|}
\hline \multicolumn{2}{|c|}{ NIST-RNAA } & & & \multirow[b]{3}{*}{$\mathrm{Cd}(\mathrm{ng} / \mathrm{g})$} \\
\hline Bottle No. & $\mathrm{P}(\%)$ & RNAA & \multirow[b]{2}{*}{$\mathrm{Cu}(\mu \mathrm{g} / \mathrm{g})$} & \\
\hline 66 & 0.101 & Bottle No & & \\
\hline 522 & 0.101 & 66 & 2.93 & 231 \\
\hline 606 & 0.103 & 227 & 2.86 & 229 \\
\hline 739 & 0.100 & 308 & 2.89 & 226 \\
\hline 803 & 0.102 & 739 & 2.90 & 245 \\
\hline 865 & 0.103 & 803 & 2.89 & 223 \\
\hline 953 & 0.104 & 986 & 2.92 & 237 \\
\hline 986 & 0.106 & 1027 & 2.88 & 247 \\
\hline 1027 & 0.102 & 1142 & 2.86 & 232 \\
\hline 1224 & 0.101 & 1333 & & 224 \\
\hline average & 0.102 & average & 2.89 & 233 \\
\hline std dev & 0.002 & std dev & 0.03 & 9 \\
\hline $\mathrm{n}$ & 10 & $\mathrm{n}$ & 8 & 9 \\
\hline
\end{tabular}

\begin{tabular}{|cccc|}
\hline $\begin{array}{l}\text { NIST-PGAA } \\
\text { Bottle No. }\end{array}$ & $\mathrm{B}(\mu \mathrm{g} / \mathrm{g})$ & $\mathrm{Cl}(\mu \mathrm{g} / \mathrm{g})$ & $\mathrm{K}(\mu \mathrm{g} / \mathrm{g})$ \\
\hline 66 & 9.66 & 410 & 4153 \\
227 & 9.60 & 414 & 4127 \\
308 & 9.44 & 417 & 4107 \\
522 & 9.62 & 424 & 4206 \\
739 & 9.62 & 416 & 4108 \\
953 & 9.63 & 414 & 4108 \\
986 & 9.63 & 418 & 4173 \\
1027 & 9.55 & 424 & 4115 \\
\hline average & 9.59 & 417 & 4137 \\
std dev & 0.07 & 5 & 37 \\
$\mathrm{n}$ & 8 & 8 & 8 \\
\hline
\end{tabular}




\begin{tabular}{|cccccccc|}
\hline \multicolumn{2}{|c}{ NIST- INAA } & & & & & & \\
Bottle No. & As $(\mathrm{ng} / \mathrm{g})$ & $\mathrm{Ba}(\mu \mathrm{g} / \mathrm{g})$ & $\mathrm{Co}(\mathrm{ng} / \mathrm{g})$ & $\mathrm{Cr}(\mathrm{ng} / \mathrm{g})$ & $\mathrm{Cs}(\mathrm{ng} / \mathrm{g})$ & $\mathrm{Fe}(\mu \mathrm{g} / \mathrm{g})$ & $\mathrm{Zn} \mu \mathrm{g} / \mathrm{g})$ \\
\hline 1333 & 38.8 & 6.7 & 62.0 & 460 & 285 & 46.4 & 38.1 \\
739 & 37.6 & 6.0 & 61.1 & 340 & 280 & 46 & 37.9 \\
522 & 40.8 & 5.9 & 60.3 & 358 & 283 & 46.2 & 38.1 \\
308 & 39.5 & 5.4 & 61.7 & 359 & 283 & 46.5 & 38.2 \\
66 & 36.8 & 6.3 & 62.5 & 354 & 281 & 45.4 & 37.5 \\
1142 & 38.8 & 5.6 & 60.6 & 349 & 283 & 46.1 & 38.0 \\
953 & -- & 5.4 & 61.9 & 524 & 281 & 45.4 & 37.8 \\
606 & 39.5 & 6.5 & 62.0 & 326 & 287 & 45.4 & 38.3 \\
308 & -- & 5.7 & 60.6 & 355 & 284 & 45.3 & 38.1 \\
227 & 39.3 & 6.1 & 60.8 & 323 & 278 & 45.8 & 37.9 \\
\hline average & 38.9 & 5.96 & 61.4 & 374.8 & 283 & 45.9 & 38.0 \\
std dev & 1.2 & 0.45 & 0.8 & 64.8 & 3 & 0.5 & 0.2 \\
$\mathrm{n}$ & 8 & 10 & 10 & 10 & 10 & 10 & 10 \\
\hline
\end{tabular}

\begin{tabular}{|ccccccc|}
\hline $\begin{array}{c}\text { NIST INAA } \\
\text { Bottle No. }\end{array}$ & $\mathrm{Ce}(\mathrm{ng} / \mathrm{g})$ & $\mathrm{Rb}(\mu \mathrm{g} / \mathrm{g})$ & $\mathrm{Sb}(\mathrm{ng} / \mathrm{g})$ & $\mathrm{Sc}(\mathrm{ng} / \mathrm{g})$ & $\mathrm{Se}(\mathrm{ng} / \mathrm{g})$ & $\mathrm{Th}(\mathrm{ng} / \mathrm{g})$ \\
\hline 1333 & 110.0 & 16.7 & 7.2 & 10.3 & 105 & 17.1 \\
739 & 104.0 & 16.5 & 7.2 & 9.87 & 104 & 17.3 \\
522 & 103.0 & 16.7 & 7.2 & 10.0 & 101 & 14.9 \\
308 & 107.0 & 16.6 & 7.0 & 10.3 & 101 & 15.7 \\
66 & 122.0 & 16.4 & 6.3 & 9.87 & 95 & 14.2 \\
1142 & 108.0 & 16.7 & 7.1 & 10.1 & 95 & 16.5 \\
953 & 114.0 & 16.4 & 7.3 & 10.1 & 95 & 16.3 \\
606 & 116.0 & 16.7 & 7.9 & 10.0 & 98 & 15.4 \\
308 & 124.0 & 16.4 & 7.0 & 10.1 & 96 & 17.6 \\
227 & 132.0 & 16.4 & 6.8 & 10.0 & 99 & 19.7 \\
\hline average & 114.0 & 16.6 & 7.1 & 10.1 & 99 & 16.5 \\
std dev & 9.5 & 0.1 & 0.4 & 0.2 & 4 & 1.6 \\
$\mathrm{n}$ & 10 & 10 & 10 & 10 & 10 & 10 \\
\hline
\end{tabular}




\begin{tabular}{|c|c|c|c|c|c|c|c|}
\hline \multicolumn{8}{|c|}{ NIST-INAA short-lived } \\
\hline Bottle No. & $\mathrm{Na} \mu \mathrm{g} / \mathrm{g}$ & $\mathrm{K} \mu \mathrm{g} / \mathrm{g}$ & $\mathrm{Mn} \mu \mathrm{g} / \mathrm{g}$ & $\mathrm{Cl} \mu \mathrm{g} / \mathrm{g}$ & $\mathrm{Al} \mu \mathrm{g} / \mathrm{g}$ & $\mathrm{Mg} \mu \mathrm{g} / \mathrm{g}$ & $\mathrm{Ca} \%$ \\
\hline 1027 & 61.1 & 4340 & 490 & 429 & 562 & 1011 & 0.253 \\
\hline 1027 & 62.3 & 4190 & 485 & 440 & & & 0.271 \\
\hline 1142 & 62.4 & 4210 & 488 & 425 & 562 & 1031 & 0.254 \\
\hline 1142 & 60.2 & 3840 & 463 & 430 & 564 & 1072 & 0.240 \\
\hline 133 & 64.5 & 4000 & 489 & 436 & 560 & & 0.246 \\
\hline 133 & 61.1 & 4380 & 486 & 432 & 587 & 976 & 0.244 \\
\hline 227 & 64.1 & 4260 & 491 & 420 & 564 & 1057 & 0.247 \\
\hline 227 & 63.2 & 4170 & 489 & 414 & 581 & 1195 & 0.247 \\
\hline 260 & 67.2 & 4010 & 490 & 428 & 557 & 909 & 0.241 \\
\hline 260 & 63.8 & 4160 & 489 & 415 & 586 & 1019 & 0.248 \\
\hline 29 & 62.1 & 4320 & 491 & 417 & 561 & 979 & 0.243 \\
\hline 29 & 63.7 & 4210 & 488 & 432 & 591 & 1108 & 0.245 \\
\hline 308 & 61.5 & 4340 & 491 & 428 & 584 & 980 & 0.251 \\
\hline 308 & 61.7 & 4240 & 488 & 429 & 608 & 1050 & 0.242 \\
\hline 522 & 62.4 & 4330 & 491 & 428 & 564 & 1063 & 0.251 \\
\hline 52 & 64.6 & 4340 & 493 & 420 & 614 & 1193 & 0.256 \\
\hline 739 & 64.4 & 4290 & 491 & 424 & 561 & 1114 & 0.257 \\
\hline 739 & 63.4 & 4330 & 487 & 420 & 573 & 1154 & 0.245 \\
\hline 803 & 61.7 & 4230 & 488 & 429 & 568 & 1035 & 0.255 \\
\hline 803 & 61.2 & 4170 & 487 & 426 & 593 & 1015 & 0.248 \\
\hline 953 & 61.7 & 4220 & 491 & 416 & 565 & 1158 & 0.236 \\
\hline 953 & 64.1 & 4160 & 486 & 407 & 575 & 1062 & 0.240 \\
\hline 986 & 62.1 & 4190 & 491 & 425 & 571 & 1006 & 0.242 \\
\hline 986 & 60.4 & 4080 & 485 & 422 & 585 & 1080 & 0.251 \\
\hline average & 62.7 & 4209 & 488 & 425 & 575 & 1058 & 0.248 \\
\hline std dev & 1.6 & 128 & 6 & 8 & 16 & 73 & 0.007 \\
\hline $\mathrm{n}$ & 24 & 24 & 24 & 24 & 23 & 22 & 24 \\
\hline
\end{tabular}

\begin{tabular}{|rr|}
\hline \multicolumn{2}{|c|}{$\begin{array}{r}\text { NIST RNAA } \\
\text { Bottle No. }\end{array}$} \\
\hline 29 & $\mathrm{Hg}(\mathrm{ng} / \mathrm{g})$ \\
66 & 43.61 \\
308 & 45.18 \\
522 & 43.13 \\
606 & 39.61 \\
1142 & 42.61 \\
1224 & 39.01 \\
\hline average & 41.5 \\
std dev & 2.8 \\
$\mathrm{n}$ & 7 \\
\hline
\end{tabular}




\begin{tabular}{|c|c|c|c|c|c|c|c|c|}
\hline USGS & ICP40 & ICP40 & ICPMS_ACID & ICP40 & ICP40 & ICP40 & ICPMS_ACID & ICP40 \\
\hline Bottle No. & $\begin{array}{c}\mathrm{Al} \\
\mathrm{mg} / \mathrm{kg}\end{array}$ & $\begin{array}{l}\mathrm{Ca} \\
\%\end{array}$ & $\begin{array}{l}\mathrm{Ca} \\
\%\end{array}$ & $\begin{array}{c}\mathrm{Cu} \\
\mathrm{mg} / \mathrm{kg}\end{array}$ & $\begin{array}{c}\mathrm{Fe} \\
\mathrm{mg} / \mathrm{kg}\end{array}$ & $\begin{array}{l}\mathrm{P} \\
\%\end{array}$ & $\begin{array}{c}\mathrm{Rb} \\
\mathrm{mg} / \mathrm{kg}\end{array}$ & $\begin{array}{l}\mathrm{Zn} \\
\mathrm{mg} / \mathrm{kg}\end{array}$ \\
\hline $766 a$ & 630 & 0.27499 & 0.221 & 2.72 & 48.8 & 0.115 & 14.7 & 40.1 \\
\hline $901 \mathrm{a}$ & 590 & 0.26378 & 0.237 & 2.69 & 46.2 & 0.112 & 15.4 & 37.8 \\
\hline $1191 \mathrm{a}$ & 625 & 0.27178 & 0.264 & 2.84 & 48.5 & 0.118 & 17.2 & 39.4 \\
\hline $1255 b$ & 600 & 0.26001 & 0.247 & 2.60 & 46.4 & 0.111 & 16.2 & 37.4 \\
\hline $491 \mathrm{a}$ & 605 & 0.27216 & 0.244 & 2.67 & 47.1 & 0.114 & 15.9 & 38.8 \\
\hline $1255 a$ & 593 & 0.25272 & 0.247 & 2.92 & 46.4 & 0.115 & 16.1 & 38.4 \\
\hline $1149 a$ & 539 & 0.23976 & 0.249 & 2.49 & 42.2 & 0.103 & 16.3 & 34.6 \\
\hline $824 b$ & 578 & 0.25546 & 0.263 & 2.63 & 45.8 & 0.111 & 17.2 & 37.4 \\
\hline $619 b$ & 571 & 0.2491 & 0.26 & 2.63 & 44.4 & 0.109 & 16.9 & 36.2 \\
\hline $491 b$ & 607 & 0.2646 & 0.247 & 2.67 & 47.4 & 0.114 & 16.2 & 38.6 \\
\hline $824 a$ & 569 & 0.2444 & 0.264 & 2.70 & 42.5 & 0.109 & 17.3 & 36.9 \\
\hline $619 a$ & 578 & 0.25064 & 0.259 & 2.68 & 45.3 & 0.111 & 17.1 & 37.1 \\
\hline $1191 b$ & 612 & 0.26924 & 0.267 & 2.79 & 48.3 & 0.117 & 17.5 & 39.1 \\
\hline $1149 b$ & 528 & 0.2331 & 0.251 & 2.38 & 41.7 & 0.101 & 16.5 & 34.0 \\
\hline $766 b$ & 622 & 0.26728 & 0.23 & 3.14 & 49.1 & 0.122 & 15.2 & 40.3 \\
\hline $901 \mathrm{~b}$ & 576 & 0.25168 & 0.245 & 2.61 & 46.0 & 0.110 & 16.1 & 37.0 \\
\hline Avg & 589 & 0.258 & 0.250 & 2.70 & "46.0 & 0.112 & 16.36 & 37.7 \\
\hline Std Dev & 29 & 0.012 & 0.013 & 0.17 & 2.3 & 0.005 & 0.82 & 1.8 \\
\hline $\mathrm{n}$ & 16 & 16 & 16 & 16 & 16 & 16 & 16 & 16 \\
\hline
\end{tabular}


Appendix B

Copy of the SRM1575a Pine Needles Certificate of Analysis 


\section{Appendix C. List of Participants in ASTM Interlaboratory Comparison Exercise}

\begin{tabular}{|l|l|l|}
\hline Participant/Analyst(s) & Affiliation & City, Country \\
\hline $\begin{array}{l}\text { Ljudmila Benedik, } \\
\text { Urska Repinc }\end{array}$ & $\begin{array}{l}\text { Dept. of Environmental Sciences } \\
\text { Jozef Stefan Institute }\end{array}$ & Ljubljana, Slovenia \\
\hline Maria Carmo-Fritas & Instituto Tecnológico E Nuclear & Sacavem, Portugal \\
\hline Sara Resnizky & $\begin{array}{l}\text { Comisión Nacional de Energía } \\
\text { Atómica }\end{array}$ & Buenos Aires, Argentina \\
\hline $\begin{array}{l}\text { Elisabete Fernandes, } \\
\text { Cláudio Luiz Gonzaga }\end{array}$ & $\begin{array}{l}\text { CENA, Laboratorio de Radioisotopos } \\
\text { University of Sao Paulo }\end{array}$ & Sao Paulo, Brazil \\
\hline Craig Stuart & Becquerel Laboratories & Mississauga, Ontario, Canada \\
\hline $\begin{array}{l}\text { Gregory Kennedy, } \\
\text { Jean St-Pierre }\end{array}$ & $\begin{array}{l}\text { Écolé Polytechnique Montréal } \\
\text { Slowpoke Laboratory }\end{array}$ & Centre-Ville, Montréal, Canada \\
\hline Jan Kucera & Czech Academy of Sciences & Rez near Prague, Czech Republic \\
\hline $\begin{array}{l}\text { M. Sundersanan, } \\
\text { S. R. Kayatsth, } \\
\text { K. K. Swain }\end{array}$ & $\begin{array}{l}\text { Government of India, } \\
\text { Bhabha Atomic Research Centre, } \\
\text { Analytical Chemistry Division }\end{array}$ & Trombay, Mumbai, India \\
\hline $\begin{array}{l}\text { E. Wallich, } \\
\text { Maxine Ranta }\end{array}$ & $\begin{array}{l}\text { Weyerhaeuser Analytical and Testing } \\
\text { Services }\end{array}$ & Federal Way, Washington, USA \\
\hline Raymund Gwozdz & TraceChem & Copenhagen, Denmark \\
\hline $\begin{array}{l}\text { Achim Berger, } \\
\text { Wolf Goerner }\end{array}$ & $\begin{array}{l}\text { Lab 1.43, Activation Analysis } \\
\text { BAM }\end{array}$ & Berlin, Germany \\
\hline Marina Frontasyeva & Joint Institute for Nuclear Research & Dubna, Russia \\
\hline Bozena Danko & Institute for Nuclear Research & Warsaw, Poland \\
\hline $\begin{array}{l}\text { Amarnath Garg, } \\
\text { Ashok Kumar }\end{array}$ & $\begin{array}{l}\text { Radioanalytical Laboratory } \\
\text { Department of Chemistry } \\
\text { Indian Institute of Technology }\end{array}$ & Roorkee, India \\
\hline $\begin{array}{l}\text { Xileio Lin } \\
\text { Richard Henkelmann }\end{array}$ & Technical University of Munich & Munich, Germany \\
\hline Sophie Ayrault & $\begin{array}{l}\text { Laboratory Pierre Sue, } \\
\text { Commissariat á l'Energie Atomique, } \\
\text { CNRS }\end{array}$ & Saclay, France \\
\hline
\end{tabular}


Analytical Results From Each Participant in the ASTM Interlaboratory Comparison Coded by Participant Numbers 


\begin{tabular}{|c|c|c|c|c|c|c|}
\hline Element & Lab No. & Average & $1 \mathrm{~s}$ & $\mathbf{n}$ & z-score & Method \\
\hline Aluminum (mg/kg) & Lab 3 & 580 & 19 & 2 & 0.0 & INAA \\
\hline Antimony (mg/kg) & Lab 3 & 0.0120 & 0.001 & 1 & 3.3 & INAA \\
\hline Arsenic (mg/kg) & Lab 3 & 0.047 & 0.009 & 2 & 2.1 & INAA \\
\hline Barium (mg/kg) & Lab 3 & 5.2 & 1 & 2 & -1.3 & INAA \\
\hline Bromine (mg/kg) & Lab 3 & 3.16 & 0.1 & 2 & 1.0 & INAA \\
\hline Cadmium (mg/kg) & Lab 3 & 0.252 & 0.014 & 2 & 0.8 & INAA \\
\hline Calcium (\%) & Lab 3 & $0.252 \%$ & $0.014 \%$ & 2 & 0.0 & INAA \\
\hline Cerium (mg/kg) & Lab 3 & 0.114 & 0.017 & 2 & 0.4 & INAA \\
\hline Cesium (mg/kg) & Lab 3 & 0.30 & 0.01 & 2 & 0.6 & INAA \\
\hline Chlorine (mg/kg) & Lab 3 & 389 & 17 & 2 & -0.8 & INAA \\
\hline Chromium (mg/kg) & Lab 3 & 0.36 & 0.03 & 2 & 0.8 & INAA \\
\hline Cobalt (mg/kg) & Lab 3 & 0.074 & 0.003 & 2 & 2.1 & INAA \\
\hline Copper (mg/kg) & Lab 3 & 3.9 & 0.6 & 2 & 3.9 & INAA \\
\hline Fluorine (mg/kg) & Lab 3 & 389 & 20 & 2 & & INAA \\
\hline Gallium (mg/kg) & Lab 3 & $<1$ & $\mathscr{\#}$ & 2 & & INAA \\
\hline Gold (mg/kg) & Lab 3 & 0.00056 & 0.00018 & 2 & & INAA \\
\hline Hafnium (mg $/ \mathrm{kg}$ ) & Lab 3 & 0.014 & 0.02 & 2 & & INAA \\
\hline Indium $(\mathrm{mg} / \mathrm{kg})$ & Lab 3 & $<0.003$ & & 2 & & INAA \\
\hline Iodine (mg/kg) & Lab 3 & $<1.5$ & & 2 & & INAA \\
\hline Iridium (mg/kg) & Lab 3 & $<0.0001$ & $\mathbb{Z}$ & 2 & & INAA \\
\hline Iron $(\mathrm{mg} / \mathrm{kg})$ & Lab 3 & 51.4 & 2.2 & 2 & 1.2 & INAA \\
\hline Lanthanum (mg/kg) & Lab 3 & 0.0565 & 0.0050 & 2 & 0.6 & INAA \\
\hline Magnesium (\%) & Lab 3 & $0.109 \%$ & $0.012 \%$ & 2 & 0.3 & INAA \\
\hline Manganese (mg/kg) & Lab 3 & 502 & 16 & 2 & 0.3 & INAA \\
\hline Mercury (mg/kg) & Lab 3 & 0.029 & 0.007 & 2 & -0.2 & INAA \\
\hline Molybdenum $(\mathrm{mg} / \mathrm{kg})$ & Lab 3 & $<0.1$ & & 2 & & INAA \\
\hline Nickel (mg/kg) & Lab 3 & $<1.3$ & & 2 & & INAA \\
\hline Potassium (\%) & Lab 3 & $0.404 \%$ & $0.015 \%$ & 2 & -0.3 & INAA \\
\hline Rubidium (mg/kg) & Lab 3 & 16.4 & 0.5 & 2 & -0.1 & INAA \\
\hline Samarium (mg/kg) & Lab 3 & 0.0078 & 0.0004 & 2 & 0.1 & INAA \\
\hline Scandium (mg/kg) & Lab 3 & 0.0116 & 0.0005 & 2 & 1.5 & INAA \\
\hline Selenium (mg/kg) & Lab 3 & 0.13 & 0.02 & 2 & 3.1 & INAA \\
\hline Silver (mg/kg) & Lab 3 & $<0.03$ & & 2 & & INAA \\
\hline Sodium (mg/kg) & Lab 3 & 63.0 & 2.4 & 2 & 0.0 & INAA \\
\hline Strontium $(\mathrm{mg} / \mathrm{kg})$ & Lab 3 & 7.2 & 1.3 & 2 & 0.5 & INAA \\
\hline Tantalum (mg/kg) & Lab 3 & $<0.005$ & & 1 & & INAA \\
\hline Thorium (mg/kg) & Lab 3 & 0.016 & 0.002 & 2 & 0.0 & INAA \\
\hline Uranium (mg/kg) & Lab 3 & $<0.04$ & & 1 & & INAA \\
\hline Vanadium (mg/kg) & Lab 3 & $<0.26$ & & 2 & $\mathbb{Z}$ & INAA \\
\hline Zinc $(\mathrm{mg} / \mathrm{kg})$ & Lab 3 & 38.5 & 2.0 & 2 & 0.1 & INAA \\
\hline
\end{tabular}




\begin{tabular}{|c|c|c|c|c|c|c|}
\hline Element & Lab No. & Average & $1 \mathrm{~s}$ & $\mathbf{n}$ & z-score & Method \\
\hline Bromine (mg/kg) & Lab 4 & 2.966 & 0.248 & 6 & 0.4 & INAA \\
\hline Cobalt (mg/kg) & Lab 4 & 0.0686 & 0.0064 & 6 & 1.2 & INAA \\
\hline Europium (mg/kg) & Lab 4 & 0.0017 & 0.0006 & 6 & & INAA \\
\hline Iron $(\mathrm{mg} / \mathrm{kg})$ & Lab 4 & 50.0 & 5.6 & 6 & 0.9 & INAA \\
\hline Lanthanum (mg/kg) & Lab 4 & 0.0565 & 0.0057 & 6 & 0.6 & INAA \\
\hline Rubidium (mg/kg) & Lab 4 & 15.8 & 2.8 & 6 & -0.4 & INAA \\
\hline Samarium (mg/kg) & $\mathrm{Lab} 4$ & 0.0080 & 0.00071 & 6 & 0.3 & INAA \\
\hline Scandium (mg/kg) & Lab 4 & 0.0106 & 0.0008 & 6 & 0.5 & INAA \\
\hline Selenium (mg/kg) & Lab 4 & 0.113 & 0.010 & 6 & 1.4 & INAA \\
\hline Zinc $(\mathrm{mg} / \mathrm{kg})$ & Lab 4 & 40.2 & 2.5 & 6 & 0.6 & INAA \\
\hline
\end{tabular}




\begin{tabular}{|c|c|c|c|c|c|c|}
\hline Element & Lab No. & Average & $1 \mathrm{~s}$ & $\mathbf{n}$ & z-score & Method \\
\hline Antimony (mg/kg) & Lab 6 & 0.0099 & 0.0035 & 4 & 1.0 & INAA \\
\hline Arsenic $(\mathrm{mg} / \mathrm{kg})$ & Lab 6 & 0.037 & 0.008 & 4 & -0.5 & INAA \\
\hline Barium (mg/kg) & Lab 6 & 5.7 & 2.3 & 4 & -0.5 & INAA \\
\hline Bromine (mg/kg) & Lab 6 & 2.84 & 0.07 & 4 & -0.1 & INAA \\
\hline Calcium (\%) & Lab 6 & $0.240 \%$ & $0.024 \%$ & 4 & -0.4 & INAA \\
\hline Cerium (mg/kg) & Lab 6 & 0.119 & 0.028 & 4 & 0.8 & INAA \\
\hline Cesium (mg/kg) & Lab 6 & 0.286 & 0.012 & 4 & 0.1 & INAA \\
\hline Chlorine (mg/kg) & Lab 6 & 396 & 21 & 4 & -0.6 & INAA \\
\hline Chromium (mg/kg) & Lab 6 & 0.290 & 0.051 & 4 & -1.3 & INAA \\
\hline Cobalt (mg/kg) & Lab 6 & 0.060 & 0.005 & 4 & -0.2 & INAA \\
\hline Europium (mg/kg) & Lab 6 & $<0.002$ & & 4 & & INAA \\
\hline Iron $(\mathrm{mg} / \mathrm{kg})$ & Lab 6 & 43.3 & 3.0 & 4 & -0.6 & INAA \\
\hline Lanthanum (mg/kg) & Lab 6 & 0.066 & 0.012 & 4 & 2.4 & INAA \\
\hline Magnesium (\%) & Lab 6 & $0.096 \%$ & $0.018 \%$ & 4 & -1.0 & INAA \\
\hline Manganese (mg/kg) & Lab 6 & 475.1 & 6.4 & 4 & -0.3 & INAA \\
\hline Potassium (\%) & Lab 6 & $0.3971 \%$ & $0.0081 \%$ & 4 & -0.5 & INAA \\
\hline Rubidium (mg/kg) & Lab 6 & 17.1 & 0.5 & 4 & 0.4 & INAA \\
\hline Samarium (mg/kg) & Lab 6 & 0.0080 & 0.0016 & 4 & 0.4 & INAA \\
\hline Scandium (mg/kg) & Lab 6 & 0.0097 & 0.0005 & 4 & -0.4 & INAA \\
\hline Sodium (mg/kg) & Lab 6 & 56.1 & 1.0 & 4 & -1.1 & INAA \\
\hline Thorium (mg/kg) & Lab 6 & 0.0178 & 0.0055 & 4 & 1.1 & INAA \\
\hline Zinc $(\mathrm{mg} / \mathrm{kg})$ & Lab 6 & 37.6 & 1.0 & 4 & -0.1 & INAA \\
\hline
\end{tabular}




\begin{tabular}{|c|c|c|c|c|c|c|}
\hline Element & Lab No. & Average & $1 \mathrm{~s}$ & $\mathbf{n}$ & z-score & Method \\
\hline Aluminum (mg/kg) & Lab 8 & 553 & 55 & 6 & -0.5 & INAA \\
\hline Antimony (mg/kg) & Lab 8 & 0.0083 & 0.0012 & 6 & -0.8 & INAA \\
\hline Arsenic $(\mathrm{mg} / \mathrm{kg})$ & Lab 8 & 0.037 & 0.006 & 6 & -0.5 & INAA \\
\hline Barium (mg/kg) & Lab 8 & 5.9 & 0.6 & 6 & -0.2 & INAA \\
\hline Bromine (mg/kg) & Lab 8 & 3.1 & 0.3 & 6 & 0.8 & INAA \\
\hline Calcium (\%) & Lab 8 & $0.243 \%$ & $0.036 \%$ & 6 & -0.3 & INAA \\
\hline Cerium (mg/kg) & Lab 8 & $<0.16$ & & 6 & & INAA \\
\hline Cesium (mg/kg) & Lab 8 & 0.30 & 0.03 & 6 & 0.6 & INAA \\
\hline Chlorine (mg/kg) & Lab 8 & 438 & 44 & 6 & 0.4 & INAA \\
\hline Chromium (mg/kg) & Lab 8 & 0.33 & 0.1 & 6 & -0.1 & INAA \\
\hline Cobalt (mg/kg) & Lab 8 & 0.067 & 0.010 & 6 & 1.0 & INAA \\
\hline Europium (mg/kg) & Lab 8 & $<0.03$ & & 6 & & INAA \\
\hline Gold (mg/kg) & Lab 8 & 0.00260 & 0.0005 & 6 & $\stackrel{2}{ }$ & INAA \\
\hline Hafnium (mg/kg) & Lab 8 & $<0.015$ & & 6 & $\ddot{Z}$ & INAA \\
\hline Iron $(\mathrm{mg} / \mathrm{kg})$ & Lab 8 & 48 & 6 & 6 & 0.4 & INAA \\
\hline Lanthanum (mg/kg) & Lab 8 & 0.058 & 0.009 & 6 & 0.9 & INAA \\
\hline Magnesium (\%) & Lab 8 & $0.102 \%$ & $0.017 \%$ & 6 & -0.3 & INAA \\
\hline Manganese (mg/kg) & Lab 8 & 465 & 46 & 6 & -0.5 & INAA \\
\hline Nickel (mg/kg) & Lab 8 & 1.29 & 0.19 & 6 & -1.2 & INAA \\
\hline Potassium (\%) & Lab 8 & $0.426 \%$ & $0.085 \%$ & 6 & 0.2 & INAA \\
\hline Rubidium (mg/kg) & Lab 8 & 18.1 & 1.8 & 6 & 1.0 & INAA \\
\hline Samarium (mg/kg) & Lab 8 & 0.0082 & 0.0008 & 6 & 0.6 & INAA \\
\hline Scandium (mg/kg) & Lab 8 & 0.0126 & 0.0025 & 6 & 2.5 & INAA \\
\hline Selenium (mg/kg) & Lab 8 & 0.13 & 0.03 & 6 & 3.1 & INAA \\
\hline Strontium (mg/kg) & Lab 8 & 8.5 & 0.8 & 6 & 2.4 & INAA \\
\hline Tantalum (mg/kg) & Lab 8 & 0.0028 & 0.0007 & 6 & $\dddot{\%}$ & INAA \\
\hline Thorium (mg/kg) & Lab 8 & 0.016 & 0.002 & 6 & 0.0 & INAA \\
\hline Tungsten & Lab 8 & 0.065 & 0.019 & 6 & & INAA \\
\hline Uranium (mg/kg) & Lab 8 & 0.0068 & 0.0014 & 6 & & INAA \\
\hline Vanadium (mg/kg) & Lab 8 & $<0.27$ & & 6 & & INAA \\
\hline Zinc $(\mathrm{mg} / \mathrm{kg})$ & Lab 8 & 38.2 & 3.8 & 6 & 0.1 & INAA \\
\hline
\end{tabular}




\begin{tabular}{|c|c|c|c|c|c|c|}
\hline Element & Lab No. & Average & $1 \mathrm{~s}$ & $\mathbf{n}$ & z-score & Method \\
\hline Cobalt (mg/kg) & Lab 10 & 0.0598 & 0.0048 & 3 & -0.2 & INAA \\
\hline Molybdenum (mg/kg) & Lab 10 & 0.0124 & 0.0012 & 4 & $\mathscr{Z}$ & INAA \\
\hline Rubidium (mg/kg) & Lab 10 & 16.18 & 1.62 & 3 & -0.2 & INAA \\
\hline Scandium (mg/kg) & Lab 10 & 0.0117 & 0.0009 & 3 & 1.6 & INAA \\
\hline Uranium (mg/kg) & $\mathrm{Lab} 10$ & 0.0071 & 0.0011 & 4 & $\dddot{Z}$ & INAA \\
\hline Zinc $(\mathrm{mg} / \mathrm{kg})$ & Lab 10 & 39.3 & 2.0 & 3 & 0.3 & INAA \\
\hline
\end{tabular}




\begin{tabular}{|c|c|c|c|c|c|c|}
\hline Element & Lab No. & Average & $1 \mathrm{~s}$ & $\mathbf{n}$ & z-score & Method \\
\hline Arsenic (mg/kg) & Lab 13a & 0.104 & 0.019 & 2 & 16.7 & INAA \\
\hline Barium (mg/kg) & Lab 13a & 9.5 & 1.7 & 3 & 5.8 & INAA \\
\hline Bromine (mg/kg) & Lab 13a & 3.08 & 0.16 & 5 & 0.7 & INAA \\
\hline Cesium (mg/kg) & Lab 13a & 0.270 & 0.017 & 3 & -0.5 & INAA \\
\hline Chromium (mg/kg) & Lab 13a & 1.33 & 0.33 & 6 & 29.9 & INAA \\
\hline Cobalt (mg/kg) & Lab 13a & 0.501 & 0.117 & 3 & 72.1 & INAA \\
\hline Gold (mg/kg) & Lab 13a & 0.00150 & 0.0004 & 3 & & INAA \\
\hline Hafnium (mg/kg) & Lab 13a & 0.116 & 0.026 & 3 & & INAA \\
\hline Iron (mg/kg) & Lab 13a & 192 & 19 & 6 & 32 & INAA \\
\hline Lanthanum (mg/kg) & Lab 13a & 0.335 & 0.022 & 3 & 53.0 & INAA \\
\hline Manganese (mg/kg) & Lab 13a & 506 & 47 & 4 & 0.4 & INAA \\
\hline Phosphorus (\%) & Lab 13a & $0.112 \%$ & $0.009 \%$ & 10 & 0.5 & INAA \\
\hline Potassium (\%) & Lab 13a & $0.431 \%$ & $0.048 \%$ & 7 & 0.3 & INAA \\
\hline Rubidium (mg/kg) & Lab 13a & 16.4 & 0.5 & 3 & -0.1 & INAA \\
\hline Scandium (mg/kg) & Lab 13a & 0.097 & 0.012 & 3 & 86.0 & INAA \\
\hline Sodium (mg/kg) & Lab 13a & 111 & 36 & 7 & 7.6 & INAA \\
\hline Thorium (mg/kg) & Lab 13a & 0.205 & 0.032 & 3 & 118 & INAA \\
\hline Zinc $(\mathrm{mg} / \mathrm{kg})$ & Lab 13a & 51.5 & 2.9 & 3 & 3.6 & INAA \\
\hline
\end{tabular}




\begin{tabular}{|c|c|c|c|c|c|c|}
\hline Element & Lab No. & Average & $1 \mathrm{~s}$ & $\mathrm{n}$ & z-score & Method \\
\hline Antimony (mg/kg) & Lab 13b & 0.0330 & 0.007 & 3 & 26.7 & INAA \\
\hline Barium (mg/kg) & Lab 13b & 8.8 & 2.4 & 3 & 4.7 & INAA \\
\hline Bromine $(\mathrm{mg} / \mathrm{kg})$ & Lab 13b & 3.91 & 0.43 & 3 & 3.6 & INAA \\
\hline Cerium (mg/kg) & Lab 13b & 0.74 & 0.10 & 3 & 57.3 & INAA \\
\hline Cesium (mg/kg) & Lab 13b & 0.293 & 0.023 & 3 & 0.4 & INAA \\
\hline Chromium (mg/kg) & Lab $13 b$ & 2.37 & 0.2 & 3 & 61.0 & INAA \\
\hline Cobalt (mg/kg) & Lab 13b & 0.541 & 0.130 & 3 & 78.7 & INAA \\
\hline Hafnium $(\mathrm{mg} / \mathrm{kg}$ ) & Lab 13b & 0.122 & 0.025 & 3 & & INAA \\
\hline $\operatorname{Iron}(\mathrm{mg} / \mathrm{kg})$ & Lab 13b & 208 & 19 & 3 & 35 & INAA \\
\hline Lanthanum (mg/kg) & Lab 13b & 0.389 & 0.03 & 3 & 63.1 & INAA \\
\hline Potassium (\%) & Lab 13b & $0.467 \%$ & $0.096 \%$ & 3 & 1.2 & INAA \\
\hline Rubidium (mg/kg) & Lab 13b & 17.2 & 1.3 & 3 & 0.4 & INAA \\
\hline Samarium (mg/kg) & Lab 13b & 0.0420 & 0.003 & 3 & 44.5 & INAA \\
\hline Scandium (mg/kg) & Lab 13b & 0.098 & 0.009 & 3 & 87.0 & INAA \\
\hline Selenium (mg/kg) & Lab 13b & 0.017 & 0.002 & 3 & -8.3 & INAA \\
\hline Thorium (mg/kg) & Lab 13b & 0.195 & 0.029 & 3 & 112 & INAA \\
\hline Ytterbium (mg/kg) & Lab 13b & 0.025 & 0.005 & 3 & & INAA \\
\hline Zinc $(\mathrm{mg} / \mathrm{kg})$ & Lab 13b & 50.4 & 7.0 & 3 & 3.3 & INAA \\
\hline
\end{tabular}

\begin{tabular}{|c|c|c|c|c|c|c|}
\hline Element & Lab No. & Average & $1 \mathrm{~s}$ & $\mathbf{n}$ & z-score & Method \\
\hline Calcium (\%) & Lab 13c & $0.457 \%$ & & 1 & 8.2 & AAS \\
\hline Iron (mg/kg) & Lab 13c & 49.9 & & 1 & 0.8 & AAS \\
\hline Magnesium (\%) & Lab 13c & $0.110 \%$ & & & 0.4 & AAS \\
\hline Manganese $(\mathrm{mg} / \mathrm{kg})$ & Lab 13c & 309 & & & -3.7 & AAS \\
\hline Potassium (\%) & Lab 13c & $0.289 \%$ & & & -3.1 & AAS \\
\hline Sodium (mg/kg) & Lab 13c & 133 & & & 11.1 & AAS \\
\hline Zinc $(\mathrm{mg} / \mathrm{kg})$ & Lab 13c & 49.9 & & & 3.1 & AAS \\
\hline
\end{tabular}




\begin{tabular}{|lcccccl|}
\hline Element & Lab No. & Average & 1s & n & z-score & Method \\
\hline Bromine $(\mathrm{mg} / \mathrm{kg})$ & Lab 15a & 3.38 & 0.16 & 1 & 1.8 & AAS \\
Manganese $(\mathrm{mg} / \mathrm{kg})$ & Lab 15a & 452 & 13 & 1 & -0.7 & AAS \\
Potassium $(\%)$ & Lab 15a & $0.398 \%$ & $0.078 \%$ & 1 & -0.5 & AAS \\
Sodium $(\mathrm{mg} / \mathrm{kg})$ & Lab 15a & 73.2 & 5.5 & 1 & 1.6 & AAS \\
\hline
\end{tabular}

\begin{tabular}{|c|c|c|c|c|c|c|}
\hline Element & Lab No. & Average & $1 \mathrm{~s}$ & n & z-score & Method \\
\hline Aluminum (mg/kg) & Lab $15 b$ & 786 & 67 & 4 & 3.6 & FAAS/GFAAS \\
\hline Cadmium (mg/kg) & $\mathrm{Lab} 15 \mathrm{~b}$ & 0.360 & 0.040 & 2 & 5.5 & FAAS/GFAAS \\
\hline Calcium (\%) & $\mathrm{Lab} 15 \mathrm{~b}$ & $0.194 \%$ & $0.029 \%$ & 4 & -2.3 & FAAS/GFAAS \\
\hline Chromium (mg/kg) & $\mathrm{Lab} 15 \mathrm{~b}$ & 0.32 & 0.06 & 2 & -0.4 & FAAS/GFAAS \\
\hline Cobalt $(\mathrm{mg} / \mathrm{kg})$ & Lab $15 b$ & $<0.035$ & & 1 & & FAAS/GFAAS \\
\hline Copper (mg/kg) & Lab $15 b$ & 1.86 & 0.18 & 2 & -3.4 & FAAS/GFAAS \\
\hline Iron $(\mathrm{mg} / \mathrm{kg})$ & $\mathrm{Lab} 15 \mathrm{~b}$ & 43.5 & 5.6 & 4 & -0.5 & FAAS/GFAAS \\
\hline Lead (mg/kg) & Lab 15b & 0.115 & 0.031 & 4 & -3.1 & FAAS/GFAAS \\
\hline Magnesium (\%) & Lab $15 b$ & $0.123 \%$ & $0.009 \%$ & 4 & 1.6 & FAAS/GFAAS \\
\hline Manganese (mg/kg) & Lab $15 b$ & 405 & 40 & 4 & -1.7 & FAAS/GFAAS \\
\hline Nickel (mg/kg) & Lab $15 b$ & 1.10 & 0.04 & 2 & -2.5 & FAAS/GFAAS \\
\hline Potassium (\%) & $\mathrm{Lab} 15 \mathrm{~b}$ & $0.44 \%$ & $0.02 \%$ & 4 & 0.6 & FAAS/GFAAS \\
\hline Silver (mg/kg) & $\mathrm{Lab} 15 \mathrm{~b}$ & $<0.05$ & & 1 & & FAAS/GFAAS \\
\hline Sodium (mg/kg) & $\mathrm{Lab} 15 \mathrm{~b}$ & 52.6 & 5.0 & 4 & -1.7 & FAAS/GFAAS \\
\hline $\operatorname{Zinc}(\mathrm{mg} / \mathrm{kg})$ & Lab $15 b$ & 29.9 & 3 & 4 & -2.1 & FAAS/GFAAS \\
\hline
\end{tabular}




\begin{tabular}{|c|c|c|c|c|c|c|}
\hline Element & Lab No. & Average & $1 \mathrm{~s}$ & $\mathbf{n}$ & z-score & Method \\
\hline Antimony (mg/kg) & Lab 16 & 0.0062 & 0.0012 & 11 & -3.1 & INAA \\
\hline Barium (mg/kg) & Lab 16 & 4.0 & 0.3 & 8 & -3.3 & INAA \\
\hline Bromine (mg/kg) & Lab 16 & 2.1 & 0.4 & 8 & -2.7 & INAA \\
\hline Cadmium (mg/kg) & Lab 16 & 0.0119 & 0.0025 & 5 & -9.5 & INAA \\
\hline Calcium (\%) & Lab 16 & $0.15 \%$ & $0.01 \%$ & 10 & -4.0 & INAA \\
\hline Cerium (mg/kg) & Lab 16 & 0.0783 & 0.0015 & 7 & -2.9 & INAA \\
\hline Cesium (mg/kg) & Lab 16 & 0.1991 & 0.0096 & 8 & -3.0 & INAA \\
\hline Chromium (mg/kg) & Lab 16 & 0.268 & 0.006 & 9 & -2.0 & INAA \\
\hline Cobalt (mg/kg) & Lab 16 & 0.0452 & 0.0028 & 8 & -2.6 & INAA \\
\hline Europium (mg/kg) & Lab 16 & 0.0011 & 0.0002 & 5 & & INAA \\
\hline Gold (mg/kg) & Lab 16 & 0.00070 & 0.0001 & 9 & & INAA \\
\hline Hafnium (mg/kg) & Lab 16 & 0.0063 & 0.0007 & 7 & & INAA \\
\hline $\operatorname{Iron}(\mathrm{mg} / \mathrm{kg})$ & Lab 16 & 32.4 & 0.1 & 3 & -3.0 & INAA \\
\hline Lanthanum (mg/kg) & Lab 16 & 0.0416 & 0.0049 & 8 & -2.2 & INAA \\
\hline Lutecium (mg/kg) & Lab 16 & 0.0006 & 0.0001 & 7 & & INAA \\
\hline Mercury (mg/kg) & Lab 16 & 0.0035 & 0.0003 & 6 & -9.1 & INAA \\
\hline Neodymium (mg/kg) & Lab 16 & 0.0283 & & 2 & & INAA \\
\hline Nickel (mg/kg) & Lab 16 & 0.9 & 0.1 & 6 & -3.9 & INAA \\
\hline Potassium (\%) & Lab 16 & $0.59 \%$ & $0.17 \%$ & 3 & 4.1 & INAA \\
\hline Rubidium (mg/kg) & Lab 16 & 0.0115 & 0.0004 & 8 & -10.0 & INAA \\
\hline Samarium (mg/kg) & Lab 16 & 0.0059 & 0.0008 & 9 & -2.3 & INAA \\
\hline Scandium (mg/kg) & Lab 16 & 0.0074 & 0.0001 & 7 & -2.7 & INAA \\
\hline Selenium (mg/kg) & Lab 16 & 0.0696 & 0.0066 & 8 & -3.0 & INAA \\
\hline Silver (mg/kg) & Lab 16 & 0.0118 & & 2 & 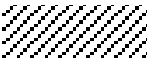 & INAA \\
\hline Sodium $(\mathrm{mg} / \mathrm{kg})$ & Lab 16 & 72.5 & 9.3 & 4 & 1.5 & INAA \\
\hline Strontium (mg/kg) & Lab 16 & 4.9 & 0.7 & 4 & -2.8 & INAA \\
\hline Tantalum (mg/kg) & Lab 16 & 0.0011 & 0.0001 & 5 & $\dddot{\#}$ & INAA \\
\hline Terbium (mg/kg) & Lab 16 & 0.0008 & 0.0001 & 4 & $\dddot{2}$ & INAA \\
\hline Thorium (mg/kg) & Lab 16 & 0.010 & 0.0002 & 7 & -3.8 & INAA \\
\hline Uranium (mg/kg) & Lab 16 & 0.0122 & & 2 & & INAA \\
\hline Ytterbium (mg/kg) & Lab 16 & 0.0033 & 0.0007 & 6 & & INAA \\
\hline Zinc $(\mathrm{mg} / \mathrm{kg})$ & Lab 16 & 27.3 & 0.3 & 9 & -2.8 & INAA \\
\hline
\end{tabular}




\begin{tabular}{|c|c|c|c|c|c|c|}
\hline Element & Lab No. & Average & $1 \mathrm{~s}$ & $\bar{n}$ & z-score & Method \\
\hline Aluminum (mg/kg) & Lab 17 & 567 & 20 & 3 & -0.2 & INAA \\
\hline Antimony (mg/kg) & Lab 17 & 0.0230 & 0.002 & 3 & 15.6 & INAA \\
\hline Arsenic (mg/kg) & Lab 17 & 0.038 & 0.002 & 3 & -0.3 & INAA \\
\hline Bromine (mg/kg) & Lab 17 & 2.7 & 0.1 & 3 & -0.6 & INAA \\
\hline Calcium (\%) & Lab 17 & $0.254 \%$ & $0.013 \%$ & 3 & 0.1 & INAA \\
\hline Cesium (mg/kg) & Lab 17 & 0.28 & 0.01 & 3 & -0.1 & INAA \\
\hline Chlorine (mg/kg) & Lab 17 & 391 & 15 & 3 & -0.7 & INAA \\
\hline Chromium (mg/kg) & Lab 17 & 0.37 & 0.02 & 3 & 1.1 & INAA \\
\hline Cobalt $(\mathrm{mg} / \mathrm{kg})$ & Lab 17 & 0.062 & 0.003 & 3 & 0.2 & INAA \\
\hline Iron $(\mathrm{mg} / \mathrm{kg})$ & Lab 17 & 45 & 3 & 3 & -0.2 & INAA \\
\hline Magnesium (\%) & Lab 17 & $0.096 \%$ & $0.003 \%$ & 3 & -0.9 & INAA \\
\hline Manganese (mg/kg) & Lab 17 & 474 & 15 & 3 & -0.3 & INAA \\
\hline Potassium (\%) & Lab 17 & $0.408 \%$ & $0.015 \%$ & 3 & -0.2 & INAA \\
\hline Rubidium (mg/kg) & Lab 17 & 16.2 & 0.05 & 3 & -0.2 & INAA \\
\hline Scandium (mg/kg) & Lab 17 & 0.0108 & 0.0004 & 3 & 0.7 & INAA \\
\hline Sodium $(\mathrm{mg} / \mathrm{kg})$ & Lab 17 & 67 & 3 & 3 & 0.6 & INAA \\
\hline Zinc $(\mathrm{mg} / \mathrm{kg})$ & Lab 17 & 38.3 & 2.0 & 3 & 0.1 & INAA \\
\hline
\end{tabular}




\begin{tabular}{|lcccccl|}
\hline Element & Lab No. & Average & 1s & n & z-score & Method \\
\hline Bromine $(\mathrm{mg} / \mathrm{kg})$ & Lab 18 & 2.75 & 0.22 & 6 & -0.4 & INAA \\
Calcium $(\%)$ & Lab 18 & $0.232 \%$ & $0.044 \%$ & 5 & -0.8 & INAA \\
Cerium $(\mathrm{mg} / \mathrm{kg})$ & Lab 18 & 0.097 & 0.025 & 6 & -1.2 & INAA \\
Cobalt $(\mathrm{mg} / \mathrm{kg})$ & Lab 18 & 0.060 & 0.004 & 6 & -0.2 & INAA \\
Iron $(\mathrm{mg} / \mathrm{kg})$ & Lab 18 & 42.7 & 4.6 & 6 & -0.7 & INAA \\
Lanthanum $(\mathrm{mg} / \mathrm{kg})$ & Lab 18 & 0.049 & 0.011 & 6 & -0.8 & INAA \\
Potassium $(\%)$ & Lab 18 & $0.402 \%$ & $0.032 \%$ & 6 & -0.4 & INAA \\
Rubidium $(\mathrm{mg} / \mathrm{kg})$ & Lab 18 & 15.3 & 1.6 & 6 & -0.7 & INAA \\
Samarium $(\mathrm{mg} / \mathrm{kg})$ & Lab 18 & 0.0078 & 0.0008 & 6 & 0.1 & INAA \\
Scandium $(\mathrm{mg} / \mathrm{kg})$ & Lab 18 & 0.0086 & 0.0007 & 6 & -1.5 & INAA \\
Sodium $(\mathrm{mg} / \mathrm{kg})$ & Lab 18 & 61 & 5 & 6 & -0.3 & INAA \\
Zinc $(\mathrm{mg} / \mathrm{kg})$ & Lab 18 & 34.7 & 3.1 & 6 & -0.9 & INAA \\
\hline
\end{tabular}




\begin{tabular}{|lcccccl|}
\hline Element & Lab No. & Average & 1s & n & z-score & Method \\
\hline Arsenic $(\mathrm{mg} / \mathrm{kg})$ & Lab 19 & 0.036 & 0.005 & 6 & -0.8 & INAA \\
Barium $(\mathrm{mg} / \mathrm{kg})$ & Lab 19 & 5.4 & 0.4 & 6 & -1.0 & INAA \\
Cesium $(\mathrm{mg} / \mathrm{kg})$ & Lab 19 & 0.289 & 0.009 & 6 & 0.2 & INAA \\
Chromium $(\mathrm{mg} / \mathrm{kg})$ & Lab 19 & 0.366 & 0.02 & 6 & 1.0 & INAA \\
Cobalt $(\mathrm{mg} / \mathrm{kg})$ & Lab 19 & 0.065 & 0.001 & 6 & 0.7 & INAA \\
Iron $(\mathrm{mg} / \mathrm{kg})$ & Lab 19 & 47.3 & 1.3 & 6 & 0.3 & INAA \\
Lanthanum $(\mathrm{mg} / \mathrm{kg})$ & Lab 19 & 0.050 & 0.004 & 6 & -0.6 & INAA \\
Potassium $(\%)$ & Lab 19 & $0.383 \%$ & $0.003 \%$ & 6 & -0.8 & INAA \\
Rubidium $(\mathrm{mg} / \mathrm{kg})$ & Lab 19 & 16.1 & 0.2 & 6 & -0.2 & INAA \\
Scandium $(\mathrm{mg} / \mathrm{kg})$ & Lab 19 & 0.0110 & 0.0004 & 6 & 0.9 & INAA \\
Sodium $(\mathrm{mg} / \mathrm{kg})$ & Lab 19 & 57 & 1 & 6 & -0.9 & INAA \\
Zinc $(\mathrm{mg} / \mathrm{kg})$ & Lab 19 & 37.2 & 0.5 & 6 & -0.2 & INAA \\
\hline
\end{tabular}




\begin{tabular}{|c|c|c|c|c|c|c|}
\hline Element & Lab No. & Average & $1 \mathrm{~s}$ & $\mathbf{n}$ & z-score & Method \\
\hline Antimony (mg/kg) & Lab 20 & 0.0086 & 0.00046 & 3 & -0.5 & INAA \\
\hline Arsenic $(\mathrm{mg} / \mathrm{kg})$ & Lab 20 & 0.040 & 0.003 & 3 & 0.3 & INAA \\
\hline Barium (mg/kg) & Lab 20 & 4.96 & 0.30 & 3 & -1.7 & INAA \\
\hline Bromine (mg/kg) & Lab 20 & 2.72 & 0.14 & 3 & -0.5 & INAA \\
\hline Calcium (\%) & Lab 20 & $0.247 \%$ & $0.012 \%$ & 3 & -0.2 & INAA \\
\hline Cerium (mg/kg) & Lab 20 & 0.0981 & 0.0057 & 3 & -1.1 & INAA \\
\hline Cesium (mg/kg) & Lab 20 & 0.266 & 0.014 & 3 & -0.6 & INAA \\
\hline Chromium (mg/kg) & Lab 20 & 0.365 & 0.020 & 3 & 0.9 & INAA \\
\hline Cobalt $(\mathrm{mg} / \mathrm{kg})$ & Lab 20 & 0.0645 & 0.0037 & 3 & 0.6 & INAA \\
\hline Europium (mg/kg) & Lab 20 & 0.00144 & 0.00012 & 3 & & INAA \\
\hline Gold (mg/kg) & Lab 20 & 0.00026 & 0.000042 & 3 & & INAA \\
\hline Hafnium (mg/kg) & Lab 20 & 0.0128 & 0.0016 & 3 & & INAA \\
\hline $\operatorname{Iron}(\mathrm{mg} / \mathrm{kg})$ & Lab 20 & 46.4 & 2.7 & 3 & 0.1 & INAA \\
\hline Lanthanum (mg/kg) & Lab 20 & 0.0479 & 0.0028 & 3 & -1.0 & INAA \\
\hline Lutecium $(\mathrm{mg} / \mathrm{kg})$ & Lab 20 & 0.00055 & 0.00006 & 3 & & INAA \\
\hline Mercury (mg/kg) & Lab 20 & 0.0391 & 0.0028 & 3 & -2.7 & INAA \\
\hline Potassium (\%) & Lab 20 & $0.422 \%$ & $0.019 \%$ & 3 & 0.1 & INAA \\
\hline Rubidium (mg/kg) & Lab 20 & 16.73 & 0.76 & 3 & 0.1 & INAA \\
\hline Samarium (mg/kg) & Lab 20 & 0.0070 & 0.00044 & 3 & -1.0 & INAA \\
\hline Scandium (mg/kg) & Lab 20 & 0.0104 & 0.0006 & 3 & 0.3 & INAA \\
\hline Selenium (mg/kg) & $\mathrm{Lab} 20$ & 0.0985 & 0.0063 & 3 & -0.1 & INAA \\
\hline Sodium $(\mathrm{mg} / \mathrm{kg})$ & Lab 20 & 64.7 & 3.1 & 3 & 0.3 & INAA \\
\hline Strontium (mg/kg) & Lab 20 & 6.76 & 0.41 & 3 & -0.1 & INAA \\
\hline Tantalum (mg/kg) & Lab 20 & 0.00135 & 0.00012 & 3 & & INAA \\
\hline Terbium (mg/kg) & Lab 20 & 0.00053 & 0.00010 & 1 & & INAA \\
\hline Thorium (mg/kg) & Lab 20 & 0.0142 & 0.0007 & 3 & -1.1 & INAA \\
\hline Ytterbium (mg/kg) & Lab 20 & 0.00215 & 0.00026 & 3 & & INAA \\
\hline Zinc $(\mathrm{mg} / \mathrm{kg})$ & $\mathrm{Lab} 20$ & 37.6 & 2.0 & 3 & -0.1 & INAA \\
\hline
\end{tabular}




\begin{tabular}{|lcccccl|}
\hline Element & Lab No. & Average & 1s & n & z-score & Method \\
\hline Bromine $(\mathrm{mg} / \mathrm{kg})$ & Lab 21 & 2.76 & 0.09 & 6 & -0.4 & INAA \\
Calcium $(\%)$ & Lab 21 & $0.243 \%$ & $0.010 \%$ & 6 & -0.3 & INAA \\
Cesium $(\mathrm{mg} / \mathrm{kg})$ & Lab 21 & 0.276 & 0.012 & 6 & -0.2 & INAA \\
Cobalt $(\mathrm{mg} / \mathrm{kg})$ & Lab 21 & 0.0628 & 0.0030 & 6 & 0.3 & INAA \\
Iron $(\mathrm{mg} / \mathrm{kg})$ & Lab 21 & 46.2 & 1.5 & 6 & 0.0 & INAA \\
Potassium $(\%)$ & Lab 21 & $0.397 \%$ & $0.006 \%$ & 6 & -0.5 & INAA \\
Rubidium $(\mathrm{mg} / \mathrm{kg})$ & Lab 21 & 17.0 & 0.5 & 6 & 0.3 & INAA \\
Scandium $(\mathrm{mg} / \mathrm{kg})$ & Lab 21 & 0.0103 & 0.0002 & 6 & 0.2 & INAA \\
Sodium $(\mathrm{mg} / \mathrm{kg})$ & Lab 21 & 61.8 & 2.0 & 6 & -0.2 & INAA \\
Zinc $(\mathrm{mg} / \mathrm{kg})$ & Lab 21 & 36.5 & 0.6 & 6 & -0.4 & INAA \\
\hline
\end{tabular}




\begin{tabular}{|c|c|c|c|c|c|c|}
\hline Element & Lab No. & Average & $1 \mathrm{~s}$ & $\mathbf{n}$ & z-score & Method \\
\hline Boron (mg/kg) & Lab 23 & $<20$ & & 3 & $\mathscr{\gtrless} \ll$ & E-6010 \\
\hline Calcium (\%) & Lab 23 & $0.246 \%$ & $0.001 \%$ & 3 & -0.2 & E-6010 \\
\hline Copper (mg/kg) & Lab 23 & 3 & 0 & 3 & 0.7 & E-6010 \\
\hline Iron $(\mathrm{mg} / \mathrm{kg})$ & $\mathrm{Lab} 23$ & 41 & 0 & 3 & -1.1 & E-6010 \\
\hline Magnesium (\%) & Lab 23 & $0.100 \%$ & $0.001 \%$ & 3 & -0.6 & E-6010 \\
\hline Manganese (mg/kg) & Lab 23 & 473 & 2 & 3 & -0.3 & E-6010 \\
\hline Nitrogen $(\%)$ [TKN] & Lab 23 & $1.11 \%$ & $0.01 \%$ & 5 & & ASTM\#1402-07 \\
\hline Phosphorus (\%) & Lab 23 & $0.124 \%$ & $0.001 \%$ & 5 & 1.6 & ASTM\#1402-07 \\
\hline Potassium (\%) & Lab 23 & $0.393 \%$ & $0.003 \%$ & 3 & -0.6 & E-6010 \\
\hline Sulfur (\%) & Lab 23 & $0.102 \%$ & $0.001 \%$ & 3 & & ASTM\#1552-90 \\
\hline Zinc $(\mathrm{mg} / \mathrm{kg})$ & Lab 23 & 38 & 0 & 3 & 0.0 & E-6010 \\
\hline
\end{tabular}




\begin{tabular}{|c|c|c|c|c|c|c|}
\hline Element & Lab No. & Average & $1 \mathrm{~s}$ & $\mathbf{n}$ & z-score & Method \\
\hline Aluminum (mg/kg) & Lab 24 & 430 & 17 & 4 & -2.6 & INAA \\
\hline Antimony (mg/kg) & Lab 24 & 0.0200 & 0.006 & 4 & 12.2 & INAA \\
\hline Arsenic $(\mathrm{mg} / \mathrm{kg})$ & Lab 24 & 0.047 & 0.006 & 4 & 2.1 & INAA \\
\hline Bromine (mg/kg) & $\mathrm{Lab} 24$ & 2.83 & 0.07 & 4 & -0.1 & INAA \\
\hline Calcium (\%) & Lab 24 & $0.273 \%$ & $0.041 \%$ & 4 & 0.9 & INAA \\
\hline Chlorine (mg/kg) & Lab 24 & 382 & 32 & 4 & -0.9 & INAA \\
\hline Lanthanum (mg/kg) & Lab 24 & 0.222 & 0.070 & 4 & 31.7 & INAA \\
\hline Magnesium (\%) & Lab 24 & $0.062 \%$ & $0.027 \%$ & 1 & -4.2 & INAA \\
\hline Manganese (mg/kg) & Lab 24 & 436 & 14 & 4 & -1.1 & INAA \\
\hline $\begin{array}{l}\text { Molybdenum } \\
(\mathrm{mg} / \mathrm{kg})\end{array}$ & Lab 24 & $<0.4$ & & 4 & & INAA \\
\hline Nickel (mg/kg) & $\mathrm{Lab} 24$ & 1.54 & 0.21 & 4 & 0.5 & INAA \\
\hline Potassium (\%) & $\mathrm{Lab} 24$ & $0.435 \%$ & $0.003 \%$ & 4 & 0.4 & INAA \\
\hline Samarium (mg/kg) & $\mathrm{Lab} 24$ & 0.0090 & 0.002 & 4 & 1.7 & INAA \\
\hline Sodium (mg/kg) & Lab 24 & 93.0 & 4.1 & 4 & 4.8 & INAA \\
\hline Uranium (mg/kg) & Lab 24 & $<0.08$ & & 4 & & INAA \\
\hline Vanadium (mg/kg) & $\mathrm{Lab} 24$ & $<0.34$ & & 4 & & INAA \\
\hline Vanadium (mg/kg) & $\mathrm{Lab} 24$ & $<0.08$ & & 4 & & INAA \\
\hline
\end{tabular}


Appendix E

Analytical Results for Each Element Reported by Participants Compared with Certificate Values and Interlaboratory Averages 


\begin{tabular}{|c|c|c|c|c|c|c|}
\hline Element & Lab No. & Average & $1 \mathrm{~s}$ & $\mathbf{n}$ & z-score & Method \\
\hline \multirow[t]{5}{*}{ Aluminum (mg/kg) } & Lab $15 b$ & 786 & 67 & 4 & 3.6 & FAAS/GFAAS \\
\hline & Lab 17 & 567 & 20 & 3 & -0.2 & INAA \\
\hline & Lab 24 & 430 & 17 & 4 & -2.6 & INAA \\
\hline & Lab 3 & 580 & 19 & 2 & 0.0 & INAA \\
\hline & Lab 8 & 553 & 55 & 6 & -0.5 & INAA \\
\hline \multirow{4}{*}{$\begin{array}{r}\text { all ASTM data } \\
\text { after rejection }\end{array}$} & $\operatorname{Avg} \pm 1 \mathrm{~s}$ & 583 & 128 & 5 & & number rejected \\
\hline & $\operatorname{Avg} \pm 1 \mathrm{~s}$ & 533 & 69 & 4 & & 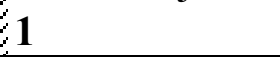 \\
\hline & NIST & 575 & 16 & 23 & & INAA \\
\hline & USGS & 589 & 29 & 16 & & ICP-AES \\
\hline
\end{tabular}

Certificate Value Certified $\quad \mathbf{5 8 0} \pm \mathbf{3 0}$

\begin{tabular}{|c|c|c|c|c|c|c|}
\hline Element & Lab No. & Average & $1 \mathrm{~s}$ & $\mathbf{n}$ & z-score & Method \\
\hline \multirow[t]{8}{*}{ Antimony (mg/kg) } & Lab 13b & 0.0330 & 0.007 & 3 & 26.7 & INAA \\
\hline & Lab 16 & 0.0062 & 0.0012 & 11 & -3.1 & INAA \\
\hline & Lab 17 & 0.0230 & 0.002 & 3 & 15.6 & INAA \\
\hline & Lab 20 & 0.0086 & 0.00046 & 3 & -0.5 & INAA \\
\hline & Lab 24 & 0.0200 & 0.006 & 4 & 12.2 & INAA \\
\hline & Lab 3 & 0.0120 & 0.001 & 1 & 3.3 & INAA \\
\hline & Lab 6 & 0.0099 & 0.0035 & 4 & 1.0 & INAA \\
\hline & Lab 8 & 0.0083 & 0.0012 & 6 & -0.8 & INAA \\
\hline all ASTM data & $\operatorname{Avg} \pm 1 \mathrm{~s}$ & 0.015 & 0.009 & 8 & & number rejected \\
\hline after rejection & $\operatorname{Avg} \pm 1 \mathrm{~s}$ & 0.009 & 0.001 & 4 & & 24 \\
\hline
\end{tabular}

\begin{tabular}{|c|c|c|c|c|c|c|}
\hline Element & Lab No. & Average & $1 \mathrm{~s}$ & $\mathbf{n}$ & z-score & Method \\
\hline \multirow{8}{*}{ Arsenic (mg/kg) } & Lab 13a & 0.104 & 0.019 & 2 & 16.7 & INAA \\
\hline & Lab 17 & 0.038 & 0.002 & 3 & -0.3 & INAA \\
\hline & Lab 19 & 0.036 & 0.005 & 6 & -0.8 & INAA \\
\hline & Lab 20 & 0.040 & 0.003 & 3 & 0.3 & INAA \\
\hline & Lab 24 & 0.047 & 0.006 & 4 & 2.1 & INAA \\
\hline & Lab 3 & 0.047 & 0.009 & 2 & 2.1 & INAA \\
\hline & Lab 6 & 0.037 & 0.008 & 4 & -0.5 & INAA \\
\hline & Lab 8 & 0.037 & 0.006 & 6 & -0.5 & INAA \\
\hline \multirow{3}{*}{$\begin{array}{r}\text { all ASTM data } \\
\text { after rejection }\end{array}$} & $\operatorname{Avg} \pm 1 \mathrm{~s}$ & 0.0483 & 0.023 & 10 & & number rejected \\
\hline & $\operatorname{Avg} \pm 1 \mathrm{~s}$ & 0.0403 & 0.005 & 9 & & 1 \\
\hline & NIST & 0.0389 & 0.00123 & 8 & & INAA \\
\hline Certificate Value & Reference & $\begin{array}{l}0.039 \pm \\
0.002\end{array}$ & & & & \\
\hline
\end{tabular}




\begin{tabular}{|c|c|c|c|c|c|c|}
\hline Element & Lab No. & Average & $1 \mathrm{~s}$ & $\mathbf{n}$ & z-score & Method \\
\hline \multirow[t]{8}{*}{ Barium (mg/kg) } & Lab 13a & 9.5 & 1.7 & 3 & 5.8 & INAA \\
\hline & Lab 13b & 8.8 & 2.4 & 3 & 4.7 & INAA \\
\hline & Lab 16 & 4.0 & 0.3 & 8 & -3.3 & INAA \\
\hline & Lab 19 & 5.4 & 0.4 & 6 & -1.0 & INAA \\
\hline & Lab 20 & 4.96 & 0.30 & 3 & -1.7 & INAA \\
\hline & Lab 3 & 5.2 & 1 & 2 & -1.3 & INAA \\
\hline & Lab 6 & 5.7 & 2.3 & 4 & -0.5 & INAA \\
\hline & Lab 8 & 5.9 & 0.6 & 6 & -0.2 & INAA \\
\hline all ASTM data & $\operatorname{Avg} \pm 1 \mathrm{~s}$ & 6.2 & 1.9 & 8 & & number rejectec \\
\hline after rejection & $\operatorname{Avg} \pm 1 \mathrm{~s}$ & 5.4 & 0.4 & 5 & & 3 \\
\hline & NIST & 5.96 & 0.45 & 10 & & INAA \\
\hline & NIST & 6.06 & 0.43 & 6 & & ICP-MS \\
\hline
\end{tabular}

$\begin{array}{lll}\text { Certificate Value } & \text { Certified } & \mathbf{6 . 0} \pm \mathbf{0 . 2}\end{array}$

\begin{tabular}{|c|c|c|c|c|c|}
\hline Element & Lab No. & Average & $1 \mathrm{~s}$ & n z-score & Method \\
\hline \multirow[t]{2}{*}{ Boron $(\mathrm{mg} / \mathrm{kg})$} & Lab 23 & $<20$ & & $3 \mathbb{W} \mathscr{W}$ & E-6010 \\
\hline & NIST & 9.59 & 0.07 & $8 \mathbb{Z}$ & PGAA \\
\hline
\end{tabular}

Certificate Value Reference $9.6 \pm 0.2$

\begin{tabular}{|c|c|c|c|c|c|c|}
\hline \begin{tabular}{|l} 
Element \\
Bromine $(\mathrm{mg} / \mathrm{kg})$
\end{tabular} & Lab No. & Average & $1 \mathrm{~s}$ & $\mathbf{n}$ & z-score & Method \\
\hline \multirow[t]{13}{*}{ Bromine $(\mathrm{mg} / \mathrm{kg}$ ) } & Lab 13a & 3.08 & 0.16 & 5 & 0.7 & INAA \\
\hline & Lab 13b & 3.91 & 0.43 & 3 & 3.6 & INAA \\
\hline & Lab 15a & 3.38 & 0.16 & 1 & 1.8 & AAS \\
\hline & Lab 16 & 2.1 & 0.4 & 8 & -2.7 & INAA \\
\hline & Lab 17 & 2.7 & 0.1 & 3 & -0.6 & INAA \\
\hline & Lab 18 & 2.75 & 0.22 & 6 & -0.4 & INAA \\
\hline & Lab 20 & 2.72 & 0.14 & 3 & -0.5 & INAA \\
\hline & Lab 21 & 2.76 & 0.09 & 6 & -0.4 & INAA \\
\hline & Lab 24 & 2.83 & 0.07 & 4 & -0.1 & INAA \\
\hline & Lab 3 & 3.16 & 0.1 & 2 & 1.0 & INAA \\
\hline & Lab 4 & 2.966 & 0.248 & 6 & 0.4 & INAA \\
\hline & Lab 6 & 2.84 & 0.07 & 4 & -0.1 & INAA \\
\hline & Lab 8 & 3.1 & 0.3 & 6 & 0.8 & INAA \\
\hline all ASTM data & $\operatorname{Avg} \pm 1$ & 2.95 & 0.42 & 13 & & number rejected \\
\hline after rejection & $\operatorname{Avg} \pm 1$ & 2.87 & 0.32 & 12 & & 1 \\
\hline
\end{tabular}




\begin{tabular}{|c|c|c|c|c|c|c|}
\hline Element & Lab No. & Average & $1 \mathrm{~s}$ & $\mathbf{n}$ & z-score & Method \\
\hline \multirow[t]{3}{*}{ Cadmium (mg/kg) } & Lab $15 b$ & 0.360 & 0.040 & 2 & 5.5 & FAAS/GFAAS \\
\hline & Lab 16 & 0.0119 & 0.0025 & 5 & -9.5 & INAA \\
\hline & Lab 3 & 0.252 & 0.014 & 2 & 0.8 & INAA \\
\hline \multirow{4}{*}{$\begin{array}{l}\text { all ASTM data } \\
\text { after rejection }\end{array}$} & $\operatorname{Avg} \pm 1 s$ & 0.208 & 0.178 & 3 & & number rejected \\
\hline & only Lab 3 & 0.252 & 0.014 & 1 & & 2 \\
\hline & NIST & 0.233 & 0.009 & 9 & & RNAA \\
\hline & NIST & 0.234 & 0.003 & 6 & & ICP-MS \\
\hline
\end{tabular}

\section{Certificate Value Certified $\mathbf{0 . 2 3 3} \pm$ 0.004}

\begin{tabular}{|c|c|c|c|c|c|c|}
\hline Element & Lab No. & Average & 1s & $\mathbf{n}$ & z-score & Method \\
\hline \multirow[t]{12}{*}{ Calcium (\%) } & Lab $13 \mathrm{c}$ & $0.457 \%$ & & 1 & 8.2 & AAS \\
\hline & $\mathrm{Lab} 15 \mathrm{~b}$ & $0.194 \%$ & $0.029 \%$ & 4 & -2.3 & FAAS/GFAAS \\
\hline & Lab 16 & $0.15 \%$ & $0.01 \%$ & 10 & -4.0 & INAA \\
\hline & Lab 17 & $0.254 \%$ & $0.013 \%$ & 3 & 0.1 & INAA \\
\hline & Lab 18 & $0.232 \%$ & $0.044 \%$ & 5 & -0.8 & INAA \\
\hline & Lab 20 & $0.247 \%$ & $0.012 \%$ & 3 & -0.2 & INAA \\
\hline & Lab 21 & $0.243 \%$ & $0.010 \%$ & 6 & -0.3 & INAA \\
\hline & Lab 23 & $0.246 \%$ & $0.001 \%$ & 3 & -0.2 & E-6010 \\
\hline & $\mathrm{Lab} 24$ & $0.273 \%$ & $0.041 \%$ & 4 & 0.9 & INAA \\
\hline & Lab 3 & $0.252 \%$ & $0.014 \%$ & 2 & 0.0 & INAA \\
\hline & Lab 6 & $0.240 \%$ & $0.024 \%$ & 4 & -0.4 & INAA \\
\hline & Lab 8 & $0.243 \%$ & $0.036 \%$ & 6 & -0.3 & INAA \\
\hline \multirow{5}{*}{$\begin{array}{r}\text { all ASTM data } \\
\text { after rejection }\end{array}$} & $\operatorname{Avg} \pm 1 s$ & $0.253 \%$ & $0.072 \%$ & \multirow{2}{*}{\multicolumn{2}{|c|}{$12 \%$}} & number rejected \\
\hline & $\operatorname{Avg} \pm 1 \mathrm{~s}$ & $0.242 \%$ & $0.020 \%$ & & & 2 \\
\hline & NIST & $0.248 \%$ & $0.007 \%$ & \multirow{3}{*}{\multicolumn{2}{|c|}{$\begin{array}{l}24 \% \approx \\
16 \% \\
16\end{array}$}} & INAA \\
\hline & USGS & $0.250 \%$ & $0.013 \%$ & & & ICP-MS \\
\hline & USGS & $0.258 \%$ & $0.012 \%$ & & & ICP-AES \\
\hline
\end{tabular}

Certificate Value Certified $\quad 0.25 \% \pm 0.02 \%$ 


\begin{tabular}{|c|c|c|c|c|c|c|}
\hline Element & Lab No. & Average & $1 \mathrm{~s}$ & $\mathbf{n}$ & z-score & Method \\
\hline \multirow{7}{*}{ Cerium (mg/kg) } & Lab 13b & 0.74 & 0.10 & 3 & 57.3 & INAA \\
\hline & Lab 16 & 0.0783 & 0.0015 & 7 & -2.9 & INAA \\
\hline & Lab 18 & 0.097 & 0.025 & 6 & -1.2 & INAA \\
\hline & Lab 20 & 0.0981 & 0.0057 & 3 & -1.1 & INAA \\
\hline & Lab 3 & 0.114 & 0.017 & 2 & 0.4 & INAA \\
\hline & Lab 6 & 0.119 & 0.028 & 4 & 0.8 & INAA \\
\hline & Lab 8 & $<0.16$ & & 6 & & INAA \\
\hline all ASTM data & $\operatorname{Avg} \pm 1 \mathrm{~s}$ & 0.208 & 0.261 & 6 & & number rejected \\
\hline after rejection & $\operatorname{Avg} \pm 1 \mathrm{~s}$ & 0.101 & 0.016 & 5 & & 1 \\
\hline & NIST & 0.11 & 0.01 & 10 & & INAA \\
\hline
\end{tabular}

\section{Certificate Value Information 0.11}

\begin{tabular}{|c|c|c|c|c|c|c|}
\hline Element & Lab No. & Average & $1 \mathrm{~s}$ & $\mathrm{n}$ & z-score & Method \\
\hline \multirow[t]{10}{*}{ Cesium (mg/kg) } & Lab 13a & 0.270 & 0.017 & 3 & -0.5 & INAA \\
\hline & Lab 13b & 0.293 & 0.023 & 3 & 0.4 & INAA \\
\hline & Lab 16 & 0.1991 & 0.0096 & 8 & -3.0 & INAA \\
\hline & Lab 17 & 0.28 & 0.01 & 3 & -0.1 & INAA \\
\hline & Lab 19 & 0.289 & 0.009 & 6 & 0.2 & INAA \\
\hline & Lab 20 & 0.266 & 0.014 & 3 & -0.6 & INAA \\
\hline & Lab 21 & 0.276 & 0.012 & 6 & -0.2 & INAA \\
\hline & Lab 3 & 0.30 & 0.01 & 2 & 0.6 & INAA \\
\hline & Lab 6 & 0.286 & 0.012 & 4 & 0.1 & INAA \\
\hline & Lab 8 & 0.30 & 0.03 & 6 & 0.6 & INAA \\
\hline \multirow[t]{2}{*}{$\begin{array}{l}\text { all ASTM data } \\
\text { after rejection }\end{array}$} & Avg $\pm 1 \mathrm{~s}$ & 0.276 & 0.029 & 10 & & number rejected \\
\hline & NIST & 0.283 & 0.003 & 10 & & INAA \\
\hline Certificate Value & Reference & $\begin{array}{l}0.283 \pm \\
0.009\end{array}$ & & & & \\
\hline
\end{tabular}




\begin{tabular}{|c|c|c|c|c|c|c|}
\hline Element & Lab No. & Average & $1 \mathrm{~s}$ & $\mathbf{n}$ & z-score & Method \\
\hline \multirow[t]{5}{*}{ Chlorine $(\mathrm{mg} / \mathrm{kg}$ ) } & Lab 17 & 391 & 15 & 3 & -0.7 & INAA \\
\hline & Lab 24 & 382 & 32 & 4 & -0.9 & INAA \\
\hline & Lab 3 & 389 & 17 & 2 & -0.8 & INAA \\
\hline & Lab 6 & 396 & 21 & 4 & -0.6 & INAA \\
\hline & Lab 8 & 438 & 44 & 6 & 0.4 & INAA \\
\hline \multirow[t]{3}{*}{$\begin{array}{l}\text { all ASTM data } \\
\text { after rejection }\end{array}$} & $\operatorname{Avg} \pm 1$ & 399 & 22 & 5 & & number rejected \\
\hline & NIST & 417 & 4.9 & 8 & & PGAA \\
\hline & NIST & 425 & 7.6 & 24 & & INAA \\
\hline
\end{tabular}

\section{Certificate Value Certified $421 \pm 7$}

\begin{tabular}{|c|c|c|c|c|c|c|}
\hline Element & Lab No. & Average & $1 \mathrm{~s}$ & $\mathbf{n}$ & z-score & Method \\
\hline \multirow[t]{10}{*}{ Chromium (mg/kg) } & Lab 13a & 1.33 & 0.33 & 6 & 29.9 & INAA \\
\hline & Lab 13b & 2.37 & 0.2 & 3 & 61.0 & INAA \\
\hline & Lab 15b & 0.32 & 0.06 & 2 & -0.4 & FAAS/GFAAS \\
\hline & Lab 16 & 0.268 & 0.006 & 9 & -2.0 & INAA \\
\hline & Lab 17 & 0.37 & 0.02 & 3 & 1.1 & INAA \\
\hline & Lab 19 & 0.366 & 0.02 & 6 & 1.0 & INAA \\
\hline & Lab 20 & 0.365 & 0.020 & 3 & 0.9 & INAA \\
\hline & Lab 3 & 0.36 & 0.03 & 2 & 0.8 & INAA \\
\hline & Lab 6 & 0.290 & 0.051 & 4 & -1.3 & INAA \\
\hline & Lab 8 & 0.33 & 0.1 & 6 & -0.1 & INAA \\
\hline $\begin{array}{l}\text { all ASTM data } \\
\text { after rejection }\end{array}$ & $\operatorname{Avg} \pm 1 \mathrm{~s}$ & $\begin{array}{l}0.637 \\
0.334\end{array}$ & $\begin{array}{l}0.686 \\
0.039\end{array}$ & $\begin{array}{c}10 \\
8\end{array}$ & & number rejected \\
\hline & NIST & 0.375 & 0.065 & 10 & & INAA \\
\hline & USGS & 0.32 & 0.02 & 16 & & ICP-AES \\
\hline & USGS & 0.39 & 0.03 & 16 & & ICP-MS \\
\hline
\end{tabular}

\section{Certificate Value Information $0.03-0.05$}




\begin{tabular}{|c|c|c|c|c|c|c|}
\hline Element & Lab No. & Average & $1 \mathrm{~s}$ & $\mathbf{n}$ & z-score & Method \\
\hline \multirow{14}{*}{ Cobalt (mg/kg) } & Lab 10 & 0.0598 & 0.0048 & 3 & -0.2 & INAA \\
\hline & Lab 13a & 0.501 & 0.117 & 3 & 72.1 & INAA \\
\hline & Lab 13b & 0.541 & 0.130 & 3 & 78.7 & INAA \\
\hline & Lab 15b & $<0.035$ & & 1 & $\mathbb{1} \mathbb{1}$ & FAAS/GFAAS \\
\hline & Lab 16 & 0.0452 & 0.0028 & 8 & -2.6 & INAA \\
\hline & Lab 17 & 0.062 & 0.003 & 3 & 0.2 & INAA \\
\hline & Lab 18 & 0.060 & 0.004 & 6 & -0.2 & INAA \\
\hline & Lab 19 & 0.065 & 0.001 & 6 & 0.7 & INAA \\
\hline & Lab 20 & 0.0645 & 0.0037 & 3 & 0.6 & INAA \\
\hline & Lab 21 & 0.0628 & 0.0030 & 6 & 0.3 & INAA \\
\hline & Lab 3 & 0.074 & 0.003 & 2 & 2.1 & INAA \\
\hline & Lab 4 & 0.0686 & 0.0064 & 6 & 1.2 & INAA \\
\hline & Lab 6 & 0.060 & 0.005 & 4 & -0.2 & INAA \\
\hline & Lab 8 & 0.067 & 0.010 & 6 & 1.0 & INAA \\
\hline \multirow{3}{*}{$\begin{array}{r}\text { all ASTM data } \\
\text { after rejection }\end{array}$} & $\operatorname{Avg} \pm 1 \mathrm{~s}$ & 0.133 & 0.172 & 13 & & number rejected \\
\hline & & 0.063 & 0.007 & 11 & & \\
\hline & NIST & 0.0614 & 0.0008 & 10 & & INAA \\
\hline
\end{tabular}

\begin{tabular}{lll}
\hline Certificate Value & Reference & $\mathbf{0 . 0 6 1} \pm$ \\
& & 0.002
\end{tabular}

\begin{tabular}{|c|c|c|c|c|c|c|}
\hline Element & Lab No. & Average & $1 \mathrm{~s}$ & $\mathbf{n}$ & z-score & Method \\
\hline \multirow[t]{3}{*}{ Copper (mg/kg) } & Lab $15 b$ & 1.86 & 0.18 & 2 & -3.4 & FAAS/GFAAS \\
\hline & Lab 23 & 3 & 0 & 3 & 0.7 & E-6010 \\
\hline & Lab 3 & 3.9 & 0.6 & 2 & 3.9 & INAA \\
\hline \multirow{4}{*}{$\begin{array}{r}\text { all ASTM data } \\
\text { after rejection }\end{array}$} & $\operatorname{Avg} \pm 1 \mathrm{~s}$ & 2.920 & 1.022 & 3 & & number rejected \\
\hline & only Lab 23 & 3 & 0 & 1 & & 2 \\
\hline & NIST & 2.89 & 0.03 & 8 & & RNAA \\
\hline & USGS & 2.70 & 0.17 & 16 & & ICP-AES \\
\hline
\end{tabular}

$\begin{array}{lll}\text { Certificate Value } & \text { Certified } & \mathbf{2 . 8} \pm \mathbf{0 . 2}\end{array}$

\begin{tabular}{|c|c|c|c|c|c|}
\hline Element & Lab No. & Average & $1 \mathrm{~s}$ & n z-score & Method \\
\hline \multirow{5}{*}{ Europium (mg/kg) } & Lab 16 & 0.0011 & 0.0002 & $5 \mathbb{2}$ & INAA \\
\hline & Lab 20 & 0.00144 & 0.00012 & 3 & INAA \\
\hline & Lab 4 & 0.0017 & 0.0006 & 6 & INAA \\
\hline & Lab 6 & $<0.002$ & & 4 & INAA \\
\hline & Lab 8 & $<0.03$ & & 6 & INAA \\
\hline
\end{tabular}




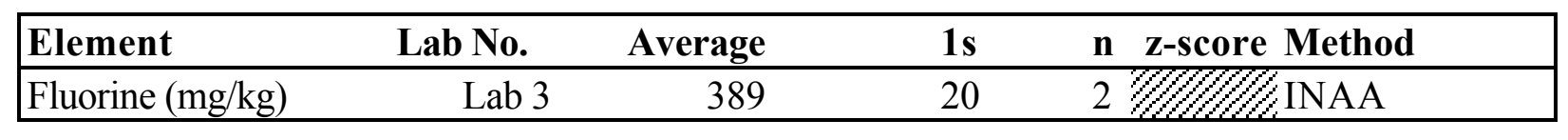

\begin{tabular}{|c|c|c|c|c|c|c|}
\hline Element & Lab No. & Average & $1 \mathrm{~s}$ & $\mathbf{n}$ & z-score & Method \\
\hline Gallium (mg/kg) & Lab 3 & $<1$ & & 2 & & INAA \\
\hline
\end{tabular}

\begin{tabular}{|c|c|c|c|c|c|}
\hline Element & Lab No. & Average & $1 \mathrm{~s}$ & n z-score & Method \\
\hline \multirow{5}{*}{ Gold (mg/kg) } & Lab 13a & 0.00150 & 0.0004 & $3 \mathbb{2}$ & INAA \\
\hline & Lab 16 & 0.00070 & 0.0001 & 9 & INAA \\
\hline & Lab 20 & 0.00026 & 0.000042 & 3 & INAA \\
\hline & Lab 3 & 0.00056 & 0.00018 & 2 & INAA \\
\hline & Lab 8 & 0.00260 & 0.0005 & 6 & INAA \\
\hline
\end{tabular}

\begin{tabular}{|c|c|c|c|c|c|}
\hline Element & Lab No. & Average & $1 \mathrm{~s}$ & n z-score & Method \\
\hline \multirow{6}{*}{ Hafnium (mg/kg) } & Lab 13a & 0.116 & 0.026 & $3 \approx \mathbb{Z}$ & INAA \\
\hline & Lab 13b & 0.122 & 0.025 & 3 & INAA \\
\hline & Lab 16 & 0.0063 & 0.0007 & 7 & INAA \\
\hline & Lab 20 & 0.0128 & 0.0016 & 3 & INAA \\
\hline & Lab 3 & 0.014 & 0.02 & 2 & INAA \\
\hline & Lab 8 & $<0.015$ & & $6 \mathbb{Z}$ & INAA \\
\hline
\end{tabular}

\begin{tabular}{|c|c|c|c|c|c|}
\hline Element & Lab No. & Average & $1 \mathrm{~s}$ & n z-score & Method \\
\hline Indium $(\mathrm{mg} / \mathrm{kg})$ & Lab 3 & $<0.003$ & & 2 & INAA \\
\hline
\end{tabular}

\begin{tabular}{|c|c|c|c|c|c|}
\hline Element & Lab No. & Average & $1 \mathrm{~s}$ & n z-score & Method \\
\hline Iodine $(\mathrm{mg} / \mathrm{kg})$ & Lab 3 & $<1.5$ & & $2 \%$ & INAA \\
\hline
\end{tabular}

\begin{tabular}{|c|c|c|c|c|c|}
\hline Element & Lab No. & Average & $1 \mathrm{~s}$ & n z-score & Method \\
\hline Iridium $(\mathrm{mg} / \mathrm{kg})$ & Lab 3 & $<0.0001$ & & $2 \mathbb{W} \mathbb{K}$ & INAA \\
\hline
\end{tabular}




\begin{tabular}{|c|c|c|c|c|c|c|}
\hline Element & Lab No. & Average & $1 \mathrm{~s}$ & $\mathbf{n}$ & z-score & Method \\
\hline \multirow[t]{15}{*}{ Iron (mg/kg) } & Lab 13a & 192 & 19 & 6 & 32 & INAA \\
\hline & Lab $13 b$ & 208 & 19 & 3 & 35 & INAA \\
\hline & Lab 13c & 49.9 & & 1 & 0.8 & AAS \\
\hline & $\mathrm{Lab} 15 \mathrm{~b}$ & 43.5 & 5.6 & 4 & -0.5 & FAAS/GFAAS \\
\hline & Lab 16 & 32.4 & 0.1 & 3 & -3.0 & INAA \\
\hline & Lab 17 & 45 & 3 & 3 & -0.2 & INAA \\
\hline & Lab 18 & 42.7 & 4.6 & 6 & -0.7 & INAA \\
\hline & Lab 19 & 47.3 & 1.3 & 6 & 0.3 & INAA \\
\hline & Lab 20 & 46.4 & 2.7 & 3 & 0.1 & INAA \\
\hline & Lab 21 & 46.2 & 1.5 & 6 & 0.0 & INAA \\
\hline & Lab 23 & 41 & 0 & 3 & -1.1 & E-6010 \\
\hline & Lab 3 & 51.4 & 2.2 & 2 & 1.2 & INAA \\
\hline & Lab 4 & 50.0 & 5.6 & 6 & 0.9 & INAA \\
\hline & Lab 6 & 43.3 & 3.0 & 4 & -0.6 & INAA \\
\hline & Lab 8 & 48 & 6 & 6 & 0.4 & INAA \\
\hline \multirow{4}{*}{$\begin{array}{l}\text { all ASTM data } \\
\text { after rejection }\end{array}$} & $\operatorname{Avg} \pm 1 \mathrm{~s}$ & 65.8 & 54.8 & \multirow{2}{*}{\multicolumn{3}{|c|}{ 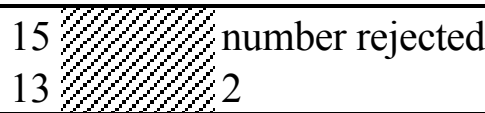 }} \\
\hline & $\operatorname{Avg} \pm 1 \mathrm{~s}$ & 45.2 & 4.9 & & & \\
\hline & NIST & 45.85 & 0.45 & \multirow{2}{*}{\multicolumn{2}{|c|}{$\begin{array}{l}10 \% \\
16\end{array}$}} & INAA \\
\hline & USGS & 46.01 & 2.31 & & & ICP-AES \\
\hline
\end{tabular}

\section{Certificate Value Certified $46 \pm 2$}

\begin{tabular}{|lcccccl|}
\hline Element & Lab No. & Average & 1s & n & z-score & Method \\
\hline Lanthanum (mg/kg) & Lab 13a & 0.335 & 0.022 & 3 & 53.0 & INAA \\
& Lab 13b & 0.389 & 0.03 & 3 & 63.1 & INAA \\
& Lab 16 & 0.0416 & 0.0049 & 8 & -2.2 & INAA \\
& Lab 18 & 0.049 & 0.011 & 6 & -0.8 & INAA \\
& Lab 19 & 0.050 & 0.004 & 6 & -0.6 & INAA \\
& Lab 20 & 0.0479 & 0.0028 & 3 & -1.0 & INAA \\
& Lab 24 & 0.222 & 0.070 & 4 & 31.7 & INAA \\
& Lab 3 & 0.0565 & 0.0050 & 2 & 0.6 & INAA \\
& Lab 4 & 0.0565 & 0.0057 & 6 & 0.6 & INAA \\
& Lab 6 & 0.066 & 0.012 & 4 & 2.4 & INAA \\
& Lab 8 & 0.058 & 0.009 & 6 & 0.9 & INAA \\
\cline { 2 - 7 } all ASTM data & Avg $\pm 1 \mathrm{~s}$ & 0.125 & 0.128 & 11 & $\mathbb{W}$ & $\mathbb{1}$ number rejected \\
after rejection & $\mathrm{Avg} \pm 1 \mathrm{~s}$ & 0.053 & 0.008 & 8 & $\mathbb{Z} 3$ \\
\hline
\end{tabular}




\begin{tabular}{|c|c|c|c|c|c|c|}
\hline$\frac{\text { Element }}{\text { Lead }(\mathrm{mg} / \mathrm{kg})}$ & Lab No. & Average & $1 \mathrm{~s}$ & $\mathbf{n}$ & z-score & Method \\
\hline \multirow[t]{2}{*}{ Lead (mg/kg) } & Lab $15 b$ & 0.115 & 0.031 & 4 & -3.1 & FAAS/GFAAS \\
\hline & NIST & 0.167 & 0.013 & 6 & & ICP-MS \\
\hline Certificate Value & Reference & $\begin{array}{l}0.167 \pm \\
0.015\end{array}$ & & & & \\
\hline
\end{tabular}

\begin{tabular}{|lcccc|}
\hline Element & Lab No. & Average & 1s & n \\
\hline zuscore & Method \\
& Lab 16 & 0.0006 & 0.0001 & 7 \\
\hline & Lab 20 & 0.00055 & 0.00006 & $3 \mathbb{1} / \mathbb{I N A A}$ \\
\hline
\end{tabular}

\begin{tabular}{|c|c|c|c|c|c|c|}
\hline Element & Lab No. & Average & $1 \mathrm{~s}$ & $\mathbf{n}$ & z-score & Method \\
\hline \multirow{8}{*}{ Magnesium (\%) } & Lab 13c & $0.110 \%$ & & & 0.4 & AAS \\
\hline & Lab $15 b$ & $0.123 \%$ & $0.009 \%$ & 4 & 1.6 & FAAS/GFAAS \\
\hline & Lab 17 & $0.096 \%$ & $0.003 \%$ & 3 & -0.9 & INAA \\
\hline & Lab 23 & $0.100 \%$ & $0.001 \%$ & 3 & -0.6 & E-6010 \\
\hline & Lab 24 & $0.062 \%$ & $0.027 \%$ & 1 & -4.2 & INAA \\
\hline & Lab 3 & $0.109 \%$ & $0.012 \%$ & 2 & 0.3 & INAA \\
\hline & Lab 6 & $0.096 \%$ & $0.018 \%$ & 4 & -1.0 & INAA \\
\hline & Lab 8 & $0.102 \%$ & $0.017 \%$ & 6 & -0.3 & INAA \\
\hline all ASTM data & $\overline{\operatorname{Avg} \pm 1 \mathrm{~s}}$ & $0.100 \%$ & $0.018 \%$ & 8 & & number rejected \\
\hline after rejection & $\operatorname{Avg} \pm 1 \mathrm{~s}$ & $0.105 \%$ & $0.010 \%$ & 7 & & \\
\hline & NIST & $0.1058 \%$ & $0.0074 \%$ & 22 & & INAA \\
\hline
\end{tabular}

\section{Certificate Value Reference $\quad 0.106 \% \pm 0.017 \%$}

\begin{tabular}{|c|c|c|c|c|c|c|}
\hline Element & Lab No. & Average & $1 \mathrm{~s}$ & $\mathbf{n}$ & z-score & Method \\
\hline \multirow[t]{10}{*}{ Manganese (mg/kg) } & Lab 13a & 506 & 47 & 4 & 0.4 & INAA \\
\hline & Lab 13c & 309 & & & -3.7 & AAS \\
\hline & Lab 15a & 452 & 13 & 1 & -0.7 & AAS \\
\hline & Lab $15 b$ & 405 & 40 & 4 & -1.7 & FAAS/GFAAS \\
\hline & Lab 17 & 474 & 15 & 3 & -0.3 & INAA \\
\hline & Lab 23 & 473 & 2 & 3 & -0.3 & E-6010 \\
\hline & Lab 24 & 436 & 14 & 4 & -1.1 & INAA \\
\hline & Lab 3 & 502 & 16 & 2 & 0.3 & INAA \\
\hline & Lab 6 & 475.1 & 6.4 & 4 & -0.3 & INAA \\
\hline & Lab 8 & 465 & 46 & 6 & -0.5 & INAA \\
\hline \multirow{3}{*}{$\begin{array}{r}\text { all ASTM data } \\
\text { after rejection }\end{array}$} & $\operatorname{Avg} \pm 1 \mathrm{~s}$ & 449.7 & 57.6 & 10 & & number rejected \\
\hline & $\operatorname{Avg} \pm 1 \mathrm{~s}$ & 465.3 & 31.4 & 9 & & 1 \\
\hline & NIST & 488 & 6 & 24 & & INAA \\
\hline
\end{tabular}

\section{Certificate Value $\quad$ Reference $488 \pm 8$}




\begin{tabular}{|c|c|c|c|c|c|c|}
\hline Element & Lab No. & Average & $1 \mathrm{~s}$ & $\mathbf{n}$ & z-score & Method \\
\hline \multirow[t]{3}{*}{ Mercury (mg/kg) } & Lab 16 & 0.0035 & 0.0003 & 6 & -9.1 & INAA \\
\hline & Lab 20 & 0.0391 & 0.0028 & 3 & -2.7 & INAA \\
\hline & Lab 3 & 0.029 & 0.007 & 2 & -0.2 & INAA \\
\hline \multirow{4}{*}{$\begin{array}{r}\text { all ASTM data } \\
\text { after rejection } \\
\end{array}$} & $\operatorname{Avg} \pm 1 \mathrm{~s}$ & 0.024 & 0.018 & 3 & & number rejected \\
\hline & $\operatorname{Avg} \pm 1 \mathrm{~s}$ & 0.034 & 0.007 & 2 & & 1 \\
\hline & NIST & 0.03993 & 0.00041 & 5 & & CV-IDMS \\
\hline & NIST & 0.0414 & 0.0029 & 7 & & RNAA \\
\hline
\end{tabular}

\section{$\begin{array}{lll}\text { Certificate Value Certified } & \mathbf{0 . 0 3 9 9} \pm \mathbf{0 . 0 0 0 7}\end{array}$}

\begin{tabular}{|c|c|c|c|c|c|}
\hline Element & Lab No. & Average & $1 \mathrm{~s}$ & n z-score & Method \\
\hline \multirow[t]{3}{*}{ Molybdenum (mg/kg) } & Lab 10 & 0.0124 & 0.0012 & $4 \nVdash \mathbb{Z}$ & INAA \\
\hline & Lab 24 & $<0.4$ & & 4 & $\angle$ INAA \\
\hline & Lab 3 & $<0.1$ & & $2 \%$ & INAA \\
\hline
\end{tabular}

\begin{tabular}{|lcccc|}
\hline Element & Lab No. & Average & 1s & n z-score Method \\
\hline Neodymium $(\mathrm{mg} / \mathrm{kg})$ & Lab 16 & 0.0283 & & $2 \nVdash / \%$ INAA \\
\hline
\end{tabular}

\begin{tabular}{|c|c|c|c|c|c|}
\hline Element & Lab No. & Average & $1 \mathrm{~s}$ & n z-score & Method \\
\hline \multirow[t]{5}{*}{ Nickel (mg/kg) } & $\mathrm{Lab} 15 \mathrm{~b}$ & 1.10 & 0.04 & $\begin{array}{ll}2 & -2.5\end{array}$ & FAAS/GFAAS \\
\hline & Lab 16 & 0.9 & 0.1 & -3.9 & INAA \\
\hline & Lab 24 & 1.54 & 0.21 & 0.5 & INAA \\
\hline & Lab 3 & $<1.3$ & & $2 \mathscr{V} /$ & INAA \\
\hline & Lab 8 & 1.29 & 0.19 & -1.2 & INAA \\
\hline \multirow{3}{*}{$\begin{array}{r}\text { all ASTM data } \\
\text { after rejection } \\
\end{array}$} & $\operatorname{Avg} \pm 1 \mathrm{~s}$ & 1.208 & 0.273 & 4 & \multirow{2}{*}{ number rejected } \\
\hline & $\operatorname{Avg} \pm 1 \mathrm{~s}$ & 1.310 & 0.221 & 3 & \\
\hline & NIST & 1.475 & 0.095 & $6 \%$ & ICP-MS \\
\hline
\end{tabular}

Certificate Value $\quad$ Reference $1.47 \pm 0.10$

\begin{tabular}{|c|c|c|c|c|c|}
\hline Element & Lab No. & Average & $1 \mathrm{~s}$ & n z-score & Method \\
\hline Nitrogen $(\%)$ [TKN] & Lab 23 & $1.11 \%$ & $0.01 \%$ & $5 \% \lll$ & $\angle$ ASTM\#1402-07 \\
\hline
\end{tabular}




\begin{tabular}{|c|c|c|c|c|c|c|}
\hline Element & Lab No. & Average & $1 \mathrm{~s}$ & $\mathbf{n}$ & z-score & Method \\
\hline \multirow{2}{*}{ Phosphorus (\%) } & Lab 13a & $0.112 \%$ & $0.009 \%$ & 10 & 0.5 & INAA \\
\hline & Lab 23 & $0.124 \%$ & $0.001 \%$ & 5 & 1.6 & ASTM\#1402-07 \\
\hline \multirow{4}{*}{$\begin{array}{r}\text { all ASTM data } \\
\text { after rejection }\end{array}$} & $\operatorname{Avg} \pm 1 \mathrm{~s}$ & $0.118 \%$ & $0.849 \%$ & 2 & & number rejected \\
\hline & $\operatorname{Avg} \pm 1 \mathrm{~s}$ & $0.118 \%$ & $0.849 \%$ & 2 & & 0 \\
\hline & NIST & $0.1023 \%$ & $0.0020 \%$ & 10 & & RNAA \\
\hline & USGS & $0.1120 \%$ & $0.0050 \%$ & 16 & & ICP-AES \\
\hline
\end{tabular}

\section{Certificate Value Certified $\quad 0.107 \% \pm 0.008 \%$}

\begin{tabular}{|c|c|c|c|c|c|c|}
\hline Element & Lab No. & Average & $1 \mathrm{~s}$ & $\mathbf{n}$ & z-score & Method \\
\hline \multirow{16}{*}{ Potassium (\%) } & Lab 13a & $0.431 \%$ & $0.048 \%$ & 7 & 0.3 & INAA \\
\hline & Lab 13b & $0.467 \%$ & $0.096 \%$ & 3 & 1.2 & INAA \\
\hline & Lab 13c & $0.289 \%$ & & & -3.1 & AAS \\
\hline & Lab 15a & $0.398 \%$ & $0.078 \%$ & 1 & -0.5 & AAS \\
\hline & Lab 15b & $0.44 \%$ & $0.02 \%$ & 4 & 0.6 & FAAS/GFAAS \\
\hline & Lab 16 & $0.59 \%$ & $0.17 \%$ & 3 & 4.1 & INAA \\
\hline & Lab 17 & $0.408 \%$ & $0.015 \%$ & 3 & -0.2 & INAA \\
\hline & Lab 18 & $0.402 \%$ & $0.032 \%$ & 6 & -0.4 & INAA \\
\hline & Lab 19 & $0.383 \%$ & $0.003 \%$ & 6 & -0.8 & INAA \\
\hline & Lab 20 & $0.422 \%$ & $0.019 \%$ & 3 & 0.1 & INAA \\
\hline & Lab 21 & $0.397 \%$ & $0.006 \%$ & 6 & -0.5 & INAA \\
\hline & $\mathrm{Lab} 23$ & $0.393 \%$ & $0.003 \%$ & 3 & -0.6 & E-6010 \\
\hline & Lab 24 & $0.435 \%$ & $0.003 \%$ & 4 & 0.4 & INAA \\
\hline & Lab 3 & $0.404 \%$ & $0.015 \%$ & 2 & -0.3 & INAA \\
\hline & Lab 6 & $0.3971 \%$ & $0.0081 \%$ & 4 & -0.5 & INAA \\
\hline & Lab 8 & $0.426 \%$ & $0.085 \%$ & 6 & 0.2 & INAA \\
\hline \multirow{4}{*}{$\begin{array}{r}\text { all ASTM data } \\
\text { after rejection }\end{array}$} & $\operatorname{Avg} \pm 1 \mathrm{~s}$ & $0.418 \%$ & $0.060 \%$ & \multirow{2}{*}{\multicolumn{2}{|c|}{$16 \mathbb{W} / \mathbb{Z}$}} & number rejected \\
\hline & $\operatorname{Avg} \pm 1 \mathrm{~s}$ & $0.415 \%$ & $0.023 \%$ & & & 2 \\
\hline & NIST & $0.4137 \%$ & $0.0037 \%$ & \multirow{2}{*}{\multicolumn{2}{|c|}{ 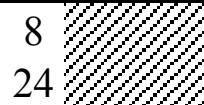 }} & PGAA \\
\hline & NIST & $0.4209 \%$ & $0.0128 \%$ & & & INAA \\
\hline
\end{tabular}

$\begin{array}{lll}\text { Certificate Value } & \text { Certified } & \mathbf{0 . 4 1 7} \% \pm 0.007 \%\end{array}$ 


\begin{tabular}{|c|c|c|c|c|c|c|}
\hline Element & Lab No. & Average & $1 \mathrm{~s}$ & $\mathbf{n}$ & z-score & Method \\
\hline \multirow[t]{13}{*}{ Rubidium (mg/kg) } & Lab 10 & 16.18 & 1.62 & 3 & -0.2 & INAA \\
\hline & Lab 13a & 16.4 & 0.5 & 3 & -0.1 & INAA \\
\hline & Lab $13 b$ & 17.2 & 1.3 & 3 & 0.4 & INAA \\
\hline & Lab 16 & 0.0115 & 0.0004 & 8 & -10.0 & INAA \\
\hline & Lab 17 & 16.2 & 0.05 & 3 & -0.2 & INAA \\
\hline & Lab 18 & 15.3 & 1.6 & 6 & -0.7 & INAA \\
\hline & Lab 19 & 16.1 & 0.2 & 6 & -0.2 & INAA \\
\hline & Lab 20 & 16.73 & 0.76 & 3 & 0.1 & INAA \\
\hline & Lab 21 & 17.0 & 0.5 & 6 & 0.3 & INAA \\
\hline & Lab 3 & 16.4 & 0.5 & 2 & -0.1 & INAA \\
\hline & Lab 4 & 15.8 & 2.8 & 6 & -0.4 & INAA \\
\hline & Lab 6 & 17.1 & 0.5 & 4 & 0.4 & INAA \\
\hline & Lab 8 & 18.1 & 1.8 & 6 & 1.0 & INAA \\
\hline \multirow{4}{*}{$\begin{array}{r}\text { all ASTM data } \\
\text { after rejection } \\
\end{array}$} & $\operatorname{Avg} \pm 1 \mathrm{~s}$ & 15.3 & 4.6 & \multirow{2}{*}{\multicolumn{2}{|c|}{132}} & number rejected \\
\hline & $\operatorname{Avg} \pm 1 \mathrm{~s}$ & 16.5 & 0.7 & & & 81 \\
\hline & NIST & 16.55 & 0.143 & \multirow{2}{*}{\multicolumn{3}{|c|}{$\begin{array}{l}10 \\
16\end{array}$}} \\
\hline & USGS & 16.36 & 0.81 & & & \\
\hline
\end{tabular}

\section{Certificate Value Certified $16.5 \pm 0.9$}

\begin{tabular}{|c|c|c|c|c|c|c|}
\hline Element & Lab No. & Average & $1 \mathrm{~s}$ & $\mathbf{n}$ & z-score & Method \\
\hline \multirow[t]{9}{*}{ Samarium (mg/kg) } & Lab 13b & 0.0420 & 0.003 & 3 & 44.5 & INAA \\
\hline & Lab 16 & 0.0059 & 0.0008 & 9 & -2.3 & INAA \\
\hline & Lab 18 & 0.0078 & 0.0008 & 6 & 0.1 & INAA \\
\hline & Lab 20 & 0.0070 & 0.00044 & 3 & -1.0 & INAA \\
\hline & Lab 24 & 0.0090 & 0.002 & 4 & 1.7 & INAA \\
\hline & Lab 3 & 0.0078 & 0.0004 & 2 & 0.1 & INAA \\
\hline & Lab 4 & 0.0080 & 0.00071 & 6 & 0.3 & INAA \\
\hline & Lab 6 & 0.0080 & 0.0016 & 4 & 0.4 & INAA \\
\hline & Lab 8 & 0.0082 & 0.0008 & 6 & 0.6 & INAA \\
\hline all ASTM data & $\operatorname{Avg} \pm 1 \mathrm{~s}$ & 0.012 & 0.011 & 9 & & number rejected \\
\hline after rejection & $\operatorname{Avg} \pm 1 \mathrm{~s}$ & 0.0077 & 0.0009 & 8 & & 1 \\
\hline
\end{tabular}




\begin{tabular}{|c|c|c|c|c|c|c|}
\hline Element & Lab No. & Average & $1 \mathrm{~s}$ & $\mathbf{n}$ & z-score & Method \\
\hline \multirow{13}{*}{ Scandium (mg/kg) } & Lab 10 & 0.0117 & 0.0009 & 3 & 1.6 & INAA \\
\hline & Lab 13a & 0.097 & 0.012 & 3 & 86.0 & INAA \\
\hline & Lab 13b & 0.098 & 0.009 & 3 & 87.0 & INAA \\
\hline & Lab 16 & 0.0074 & 0.0001 & 7 & -2.7 & INAA \\
\hline & Lab 17 & 0.0108 & 0.0004 & 3 & 0.7 & INAA \\
\hline & Lab 18 & 0.0086 & 0.0007 & 6 & -1.5 & INAA \\
\hline & Lab 19 & 0.0110 & 0.0004 & 6 & 0.9 & INAA \\
\hline & Lab 20 & 0.0104 & 0.0006 & 3 & 0.3 & INAA \\
\hline & Lab 21 & 0.0103 & 0.0002 & 6 & 0.2 & INAA \\
\hline & Lab 3 & 0.0116 & 0.0005 & 2 & 1.5 & INAA \\
\hline & Lab 4 & 0.0106 & 0.0008 & 6 & 0.5 & INAA \\
\hline & Lab 6 & 0.0097 & 0.0005 & 4 & -0.4 & INAA \\
\hline & Lab 8 & 0.0126 & 0.0025 & 6 & 2.5 & INAA \\
\hline \multirow{3}{*}{$\begin{array}{r}\text { all ASTM data } \\
\text { after rejection }\end{array}$} & $\operatorname{Avg} \pm 1 \mathrm{~s}$ & 0.024 & 0.033 & 13 & & number rejected \\
\hline & $\operatorname{Avg} \pm 1 \mathrm{~s}$ & 0.0104 & 0.0015 & 11 & & 2 \\
\hline & NIST & 0.01006 & 0.00015 & 10 & & INAA \\
\hline
\end{tabular}

\section{Certificate Value $\quad$ Reference $\quad 0.0101 \pm 0.0003$}

\begin{tabular}{|c|c|c|c|c|c|c|}
\hline Element & Lab No. & Average & $1 \mathrm{~s}$ & $\mathbf{n}$ & z-score & Method \\
\hline \multirow[t]{6}{*}{ Selenium $(\mathrm{mg} / \mathrm{kg})$} & Lab 13b & 0.017 & 0.002 & 3 & -8.3 & INAA \\
\hline & Lab 16 & 0.0696 & 0.0066 & 8 & -3.0 & INAA \\
\hline & Lab 20 & 0.0985 & 0.0063 & 3 & -0.1 & INAA \\
\hline & Lab 3 & 0.13 & 0.02 & 2 & 3.1 & INAA \\
\hline & Lab 4 & 0.113 & 0.010 & 6 & 1.4 & INAA \\
\hline & Lab 8 & 0.13 & 0.03 & 6 & 3.1 & INAA \\
\hline \multirow{3}{*}{$\begin{array}{r}\text { all ASTM data } \\
\text { after rejection }\end{array}$} & $\operatorname{Avg} \pm 1 \mathrm{~s}$ & 0.093 & 0.044 & 6 & & number rejected \\
\hline & $\operatorname{Avg} \pm 1 \mathrm{~s}$ & 0.094 & 0.022 & 3 & & 3 \\
\hline & NIST & 0.099 & 0.004 & 10 & & INAA \\
\hline
\end{tabular}

\begin{tabular}{lll}
\hline Certificate Value & Reference & $0.099 \pm$ \\
& & 0.004
\end{tabular}

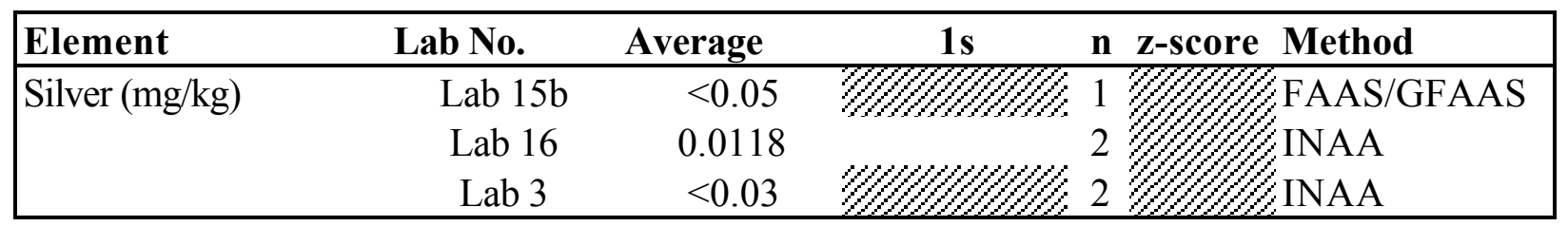




\begin{tabular}{|c|c|c|c|c|c|c|}
\hline Element & Lab No. & Average & $1 \mathrm{~s}$ & $\mathbf{n}$ & z-score & Method \\
\hline \multirow{13}{*}{ Sodium $(\mathrm{mg} / \mathrm{kg})$} & Lab 13a & 111 & 36 & 7 & 7.6 & INAA \\
\hline & Lab 13c & 133 & & & 11.1 & AAS \\
\hline & Lab 15a & 73.2 & 5.5 & 1 & 1.6 & AAS \\
\hline & Lab 15b & 52.6 & 5.0 & 4 & -1.7 & FAAS/GFAAS \\
\hline & Lab 16 & 72.5 & 9.3 & 4 & 1.5 & INAA \\
\hline & Lab 17 & 67 & 3 & 3 & 0.6 & INAA \\
\hline & Lab 18 & 61 & 5 & 6 & -0.3 & INAA \\
\hline & Lab 19 & 57 & 1 & 6 & -0.9 & INAA \\
\hline & Lab 20 & 64.7 & 3.1 & 3 & 0.3 & INAA \\
\hline & Lab 21 & 61.8 & 2.0 & 6 & -0.2 & INAA \\
\hline & Lab 24 & 93.0 & 4.1 & 4 & 4.8 & INAA \\
\hline & Lab 3 & 63.0 & 2.4 & 2 & 0.0 & INAA \\
\hline & Lab 6 & 56.1 & 1.0 & 4 & -1.1 & INAA \\
\hline all ASTM data & $\operatorname{Avg} \pm 1 \mathrm{~s}$ & 74.3 & 23.9 & 13 & & number rejected \\
\hline after rejection & $\operatorname{Avg} \pm 1 \mathrm{~s}$ & 62.9 & 6.7 & 10 & & 3 \\
\hline & NIST & 62.7 & 1.63 & 24 & & INAA \\
\hline
\end{tabular}

\section{Certificate Value Reference $63 \pm 1$}

\begin{tabular}{|c|c|c|c|c|c|c|}
\hline $\begin{array}{l}\text { Element } \\
\text { Strontium }(\mathrm{mg} / \mathrm{kg})\end{array}$ & Lab No. & Average & $1 \mathrm{~s}$ & $\mathrm{n}$ & z-score & Method \\
\hline \multirow{4}{*}{ Strontium $(\mathrm{mg} / \mathrm{kg})$} & Lab 16 & 4.9 & 0.7 & 4 & -2.8 & INAA \\
\hline & Lab 20 & 6.76 & 0.41 & 3 & -0.1 & INAA \\
\hline & Lab 3 & 7.2 & 1.3 & 2 & 0.5 & INAA \\
\hline & Lab 8 & 8.5 & 0.8 & 6 & 2.4 & INAA \\
\hline $\begin{array}{l}\text { all ASTM data } \\
\text { after rejection }\end{array}$ & $\begin{array}{l}\operatorname{Avg} \pm 1 \\
\operatorname{Avg} \pm 1\end{array}$ & 6.8 & 1.5 & 4 & & number rejected \\
\hline
\end{tabular}

\begin{tabular}{|c|c|c|c|c|c|}
\hline Element & Lab No. & Average & $1 \mathrm{~s}$ & n z-score & Method \\
\hline Sulfur (\%) & Lab 23 & $0.102 \%$ & $0.001 \%$ & $3 \mathbb{W} \mathscr{\mathbb { Z }}$ & ASTM $\# 1552-90$ \\
\hline
\end{tabular}

\begin{tabular}{|c|c|c|c|c|c|}
\hline Element & Lab No. & Average & $1 \mathrm{~s}$ & n z-score & Method \\
\hline \multirow[t]{4}{*}{ Tantalum $(\mathrm{mg} / \mathrm{kg})$} & Lab 16 & 0.0011 & 0.0001 & $5 \nVdash \mathbb{}$ & INAA \\
\hline & Lab 20 & 0.00135 & 0.00012 & 3 & INAA \\
\hline & Lab 3 & $<0.005$ & & 1 & INAA \\
\hline & Lab 8 & 0.0028 & 0.0007 & 6 & INAA \\
\hline
\end{tabular}




\begin{tabular}{|c|c|c|c|c|c|}
\hline Element & Lab No. & Average & $1 \mathrm{~s}$ & n z-score & Method \\
\hline \multirow[t]{2}{*}{ Terbium (mg/kg) } & Lab 16 & 0.0008 & 0.0001 & $4 \mathbb{W} \mathbb{Z}$ & INAA \\
\hline & Lab 20 & 0.00053 & 0.00010 & 1 & INAA \\
\hline
\end{tabular}

\begin{tabular}{|c|c|c|c|c|c|c|}
\hline Element & Lab No. & Average & $1 \mathrm{~s}$ & $\mathbf{n}$ & z-score & Method \\
\hline \multirow[t]{7}{*}{ Thorium $(\mathrm{mg} / \mathrm{kg})$} & Lab 13a & 0.205 & 0.032 & 3 & 118 & INAA \\
\hline & Lab 13b & 0.195 & 0.029 & 3 & 112 & INAA \\
\hline & Lab 16 & 0.010 & 0.0002 & 7 & -3.8 & INAA \\
\hline & Lab 20 & 0.0142 & 0.0007 & 3 & -1.1 & INAA \\
\hline & Lab 3 & 0.016 & 0.002 & 2 & 0.0 & INAA \\
\hline & Lab 6 & 0.0178 & 0.0055 & 4 & 1.1 & INAA \\
\hline & Lab 8 & 0.016 & 0.002 & 6 & 0.0 & INAA \\
\hline all ASTM data & $\operatorname{Avg} \pm 1 \mathrm{~s}$ & 0.068 & 0.0905 & 7 & & number rejected \\
\hline after rejection & $\operatorname{Avg} \pm 1 \mathrm{~s}$ & 0.016 & 0.001 & 4 & & 3 \\
\hline
\end{tabular}

\begin{tabular}{|lcccc|}
\hline Element & Lab No. & Average & 1s & n z-score Method \\
\hline Tungsten $(\mathrm{mg} / \mathrm{kg})$ & Lab 8 & 0.065 & 0.019 & $6 \mathbb{W} \mathbb{\mathscr { K }} / \mathrm{INAA}$ \\
\hline
\end{tabular}

\begin{tabular}{|c|c|c|c|c|c|}
\hline Element & Lab No. & Average & $1 \mathrm{~s}$ & n z-score & Method \\
\hline \multirow{5}{*}{ Uranium (mg/kg) } & Lab 10 & 0.0071 & 0.0011 & $4 \mathbb{2}$ & INAA \\
\hline & Lab 16 & 0.0122 & & 2 & INAA \\
\hline & Lab 24 & $<0.08$ & & 4 & INAA \\
\hline & Lab 3 & $<0.04$ & & 1 & INAA \\
\hline & Lab 8 & 0.0068 & 0.0014 & 6 & INAA \\
\hline
\end{tabular}

\begin{tabular}{|c|c|c|c|c|c|}
\hline Element & Lab No. & Average & $1 \mathrm{~s}$ & n z-score & Method \\
\hline \multirow{4}{*}{ Vanadium (mg/kg) } & Lab 24 & $<0.34$ & & $4^{4} \mathbb{W}$ & INAA \\
\hline & Lab 24 & $<0.08$ & & 4 & INAA \\
\hline & Lab 3 & $<0.26$ & & 2 & INAA \\
\hline & Lab 8 & $<0.27$ & & 63 & INAA \\
\hline
\end{tabular}




\begin{tabular}{|c|c|c|c|c|c|}
\hline Element & Lab No. & Average & $1 \mathrm{~s}$ & n z-score & Method \\
\hline \multirow{3}{*}{ Ytterbium (mg/kg) } & Lab 13b & 0.025 & 0.005 & $3 \mathbb{2}$ & INAA \\
\hline & Lab 16 & 0.0033 & 0.0007 & 6 & INAA \\
\hline & Lab 20 & 0.00215 & 0.00026 & 3 & INAA \\
\hline
\end{tabular}

\begin{tabular}{|c|c|c|c|c|c|c|}
\hline Element & Lab No. & Average & $1 \mathrm{~s}$ & $\bar{n}$ & z-score & Method \\
\hline \multirow[t]{16}{*}{ Zinc (mg/kg) A334 } & Lab 10 & 39.3 & 2.0 & 3 & 0.3 & INAA \\
\hline & Lab 13a & 51.5 & 2.9 & 3 & 3.6 & INAA \\
\hline & Lab 13b & 50.4 & 7.0 & 3 & 3.3 & INAA \\
\hline & Lab $13 c$ & 49.9 & & & 3.1 & AAS \\
\hline & Lab 15b & 29.9 & 3 & 4 & -2.1 & FAAS/GFAAS \\
\hline & Lab 16 & 27.3 & 0.3 & 9 & -2.8 & INAA \\
\hline & Lab 17 & 38.3 & 2.0 & 3 & 0.1 & INAA \\
\hline & Lab 18 & 34.7 & 3.1 & 6 & -0.9 & INAA \\
\hline & Lab 19 & 37.2 & 0.5 & 6 & -0.2 & INAA \\
\hline & Lab 20 & 37.6 & 2.0 & 3 & -0.1 & INAA \\
\hline & Lab 21 & 36.5 & 0.6 & 6 & -0.4 & INAA \\
\hline & Lab 23 & 38 & 0 & 3 & 0.0 & E-6010 \\
\hline & Lab 3 & 38.5 & 2.0 & 2 & 0.1 & INAA \\
\hline & Lab 4 & 40.2 & 2.5 & 6 & 0.6 & INAA \\
\hline & Lab 6 & 37.6 & 1.0 & 4 & -0.1 & INAA \\
\hline & Lab 8 & 38.2 & 3.8 & 6 & 0.1 & INAA \\
\hline \multirow{4}{*}{$\begin{array}{r}\text { all ASTM data } \\
\text { after rejection }\end{array}$} & $\operatorname{Avg} \pm 1 \mathrm{~s}$ & 39.1 & 6.6 & \multirow{2}{*}{\multicolumn{2}{|c|}{$\begin{array}{l}16 \mathbb{W} \\
13 \mathbb{Z}\end{array}$}} & number rejected \\
\hline & $\operatorname{Avg} \pm 1 \mathrm{~s}$ & 36.4 & 3.7 & & & 3 \\
\hline & NIST & 38.0 & 0.2 & \multirow{2}{*}{\multicolumn{2}{|c|}{$10 \mathbb{Z}$}} & INAA \\
\hline & USGS & 37.7 & 1.8 & & & ICP-AES \\
\hline
\end{tabular}

\section{Certificate Value Certified $\quad \mathbf{3 8} \pm \mathbf{2}$}

\begin{tabular}{|c|c|c|c|c|c|}
\hline Isotope & Lab No. & Average & $1 \mathrm{~s}$ & n z-score & Method \\
\hline U-238 & Lab 2 & 0.00490 & 0.00083 & $6 \mathbb{W} \mathbb{Z} /$ & Isotope Analysis \\
\hline Th-232 & Lab 2 & 0.0270 & 0.0055 & 6 & Isotope Analysis \\
\hline
\end{tabular}

